\title{
Lewis acid-Catalysed Denitrogenative Transannulation of Pyridotriazoles with Nitriles: Synthesis of Imidazopyridines
}

Abhisek Joshi, Darapaneni Chandra Mohan and Subbarayappa Adimurthy*

Academy of Scientific \& Innovative Research, CSIR-Central Salt \& Marine Chemicals

Research Institute, G. B. Marg, Bhavnagar-364 002. Gujarat (INDIA)

\section{E-mail: adimurthy@csmcri.org}

\section{Table of Contents}

Optimization Table

${ }^{1} \mathrm{H} \&{ }^{13} \mathrm{C}$ - NMR Spectra of all products 


\section{Optimization Table (S1)}

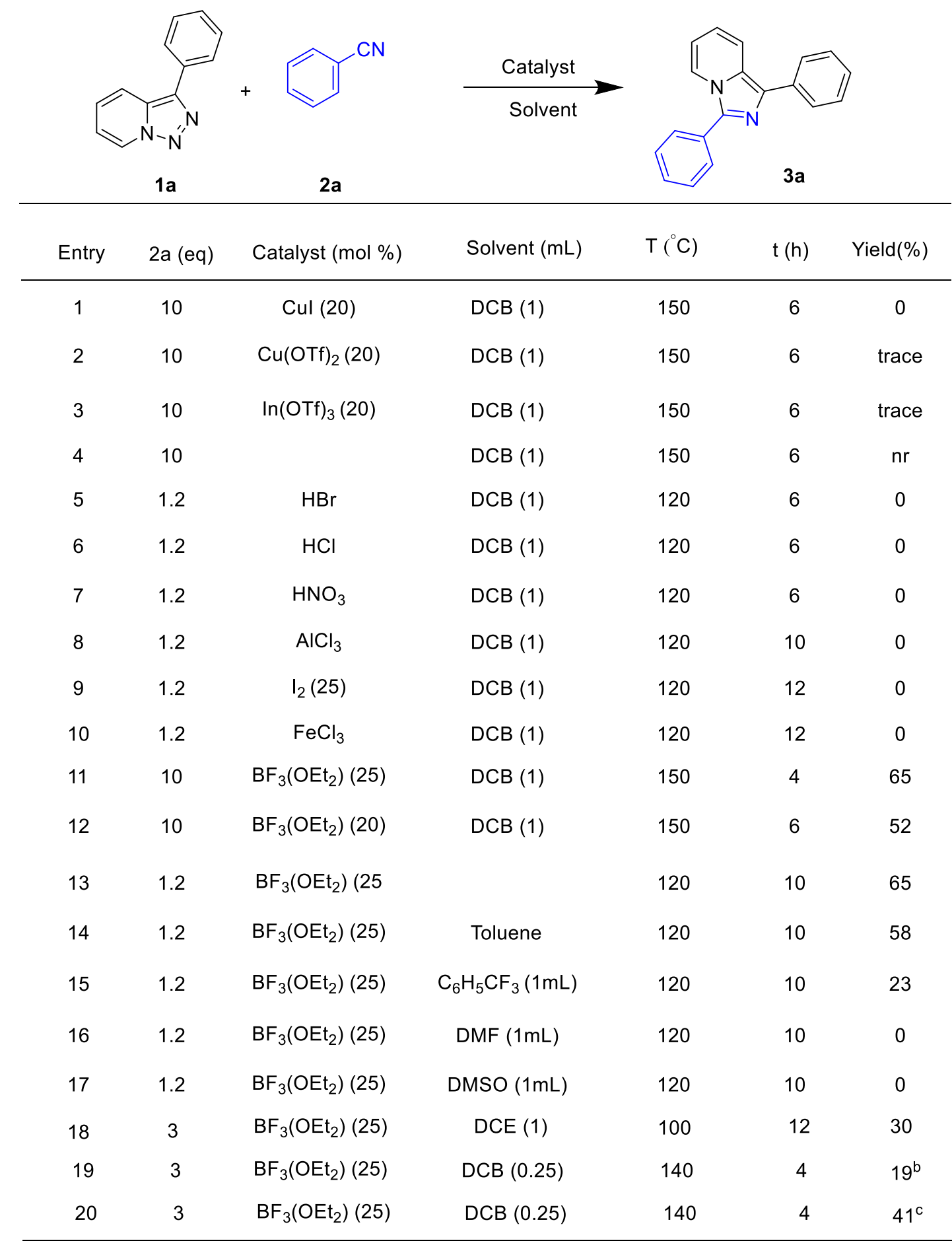

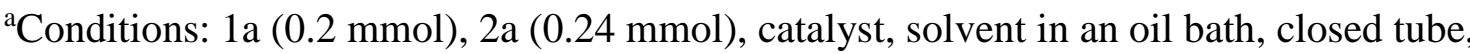
isolated yield. ${ }^{\mathrm{b}}$ Oxygen atmosphere. ${ }^{\mathrm{c}}$ Argon atmosphere. [nr: no reaction]. 


\section{Copies of ${ }^{1} \mathrm{H} \&{ }^{13} \mathrm{C}$ NMR spectra}

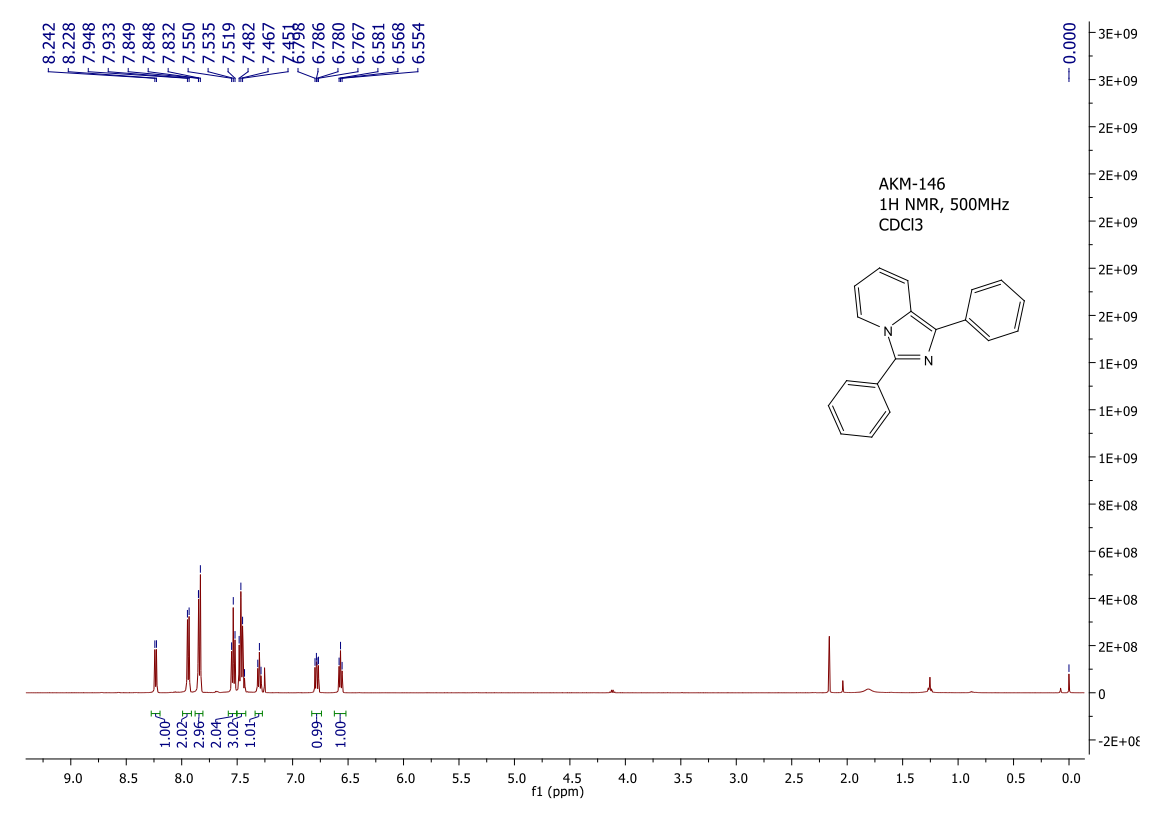

${ }^{1} \mathrm{H}$ NMR of $\mathbf{3 a}$

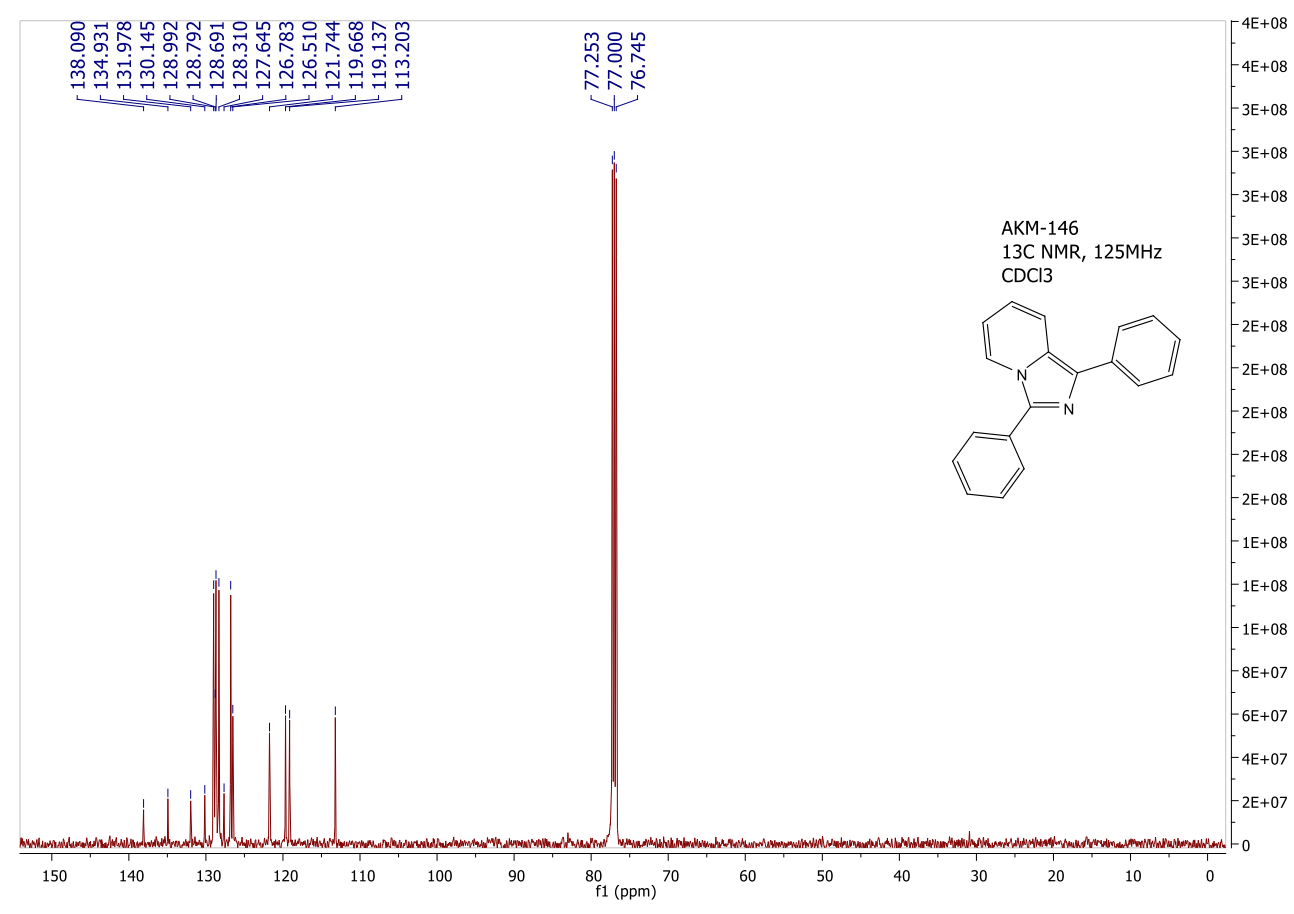

${ }^{13} \mathrm{C}$ NMR of $\mathbf{3 a}$ 


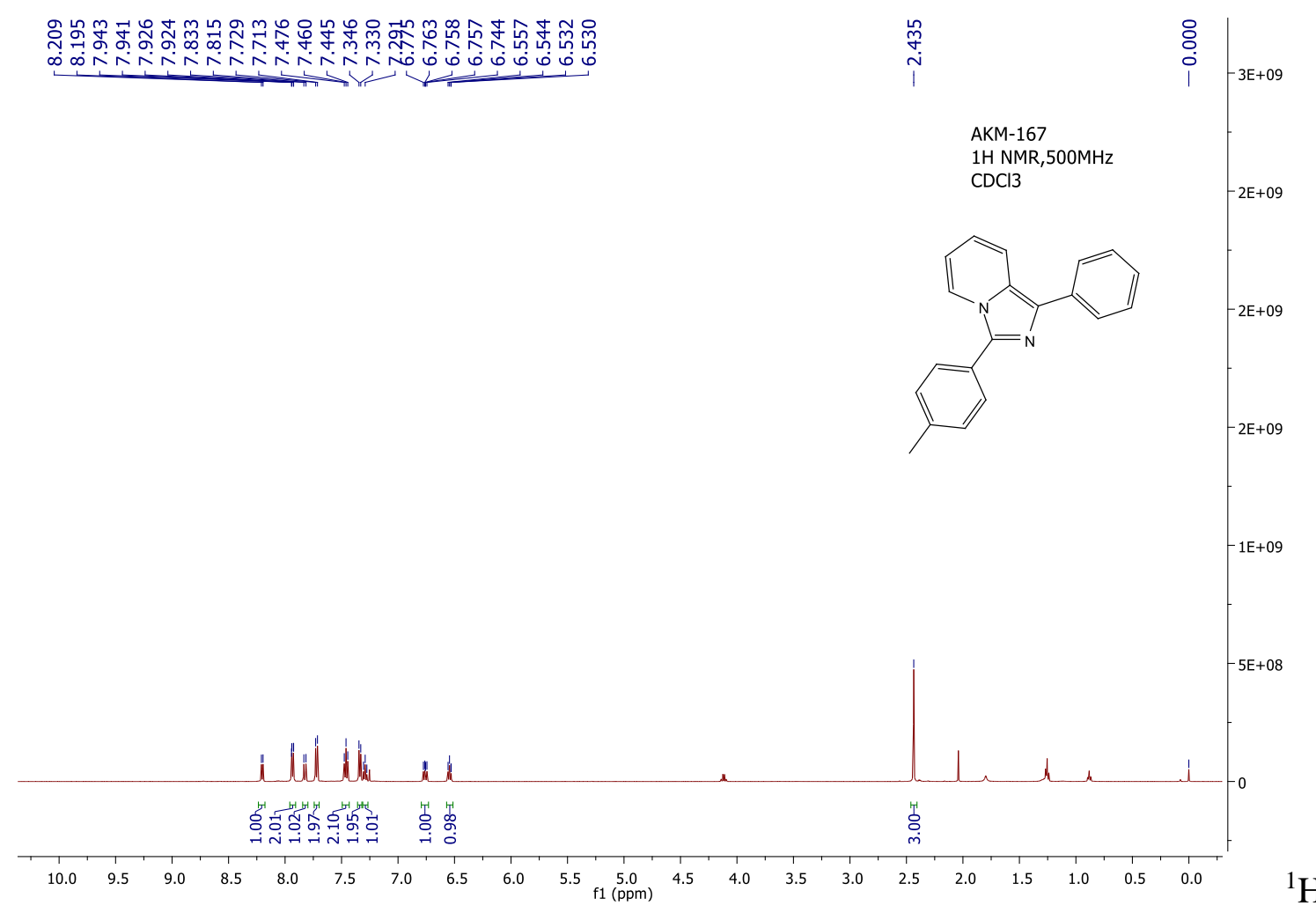

\section{NMR of $\mathbf{3 b}$}

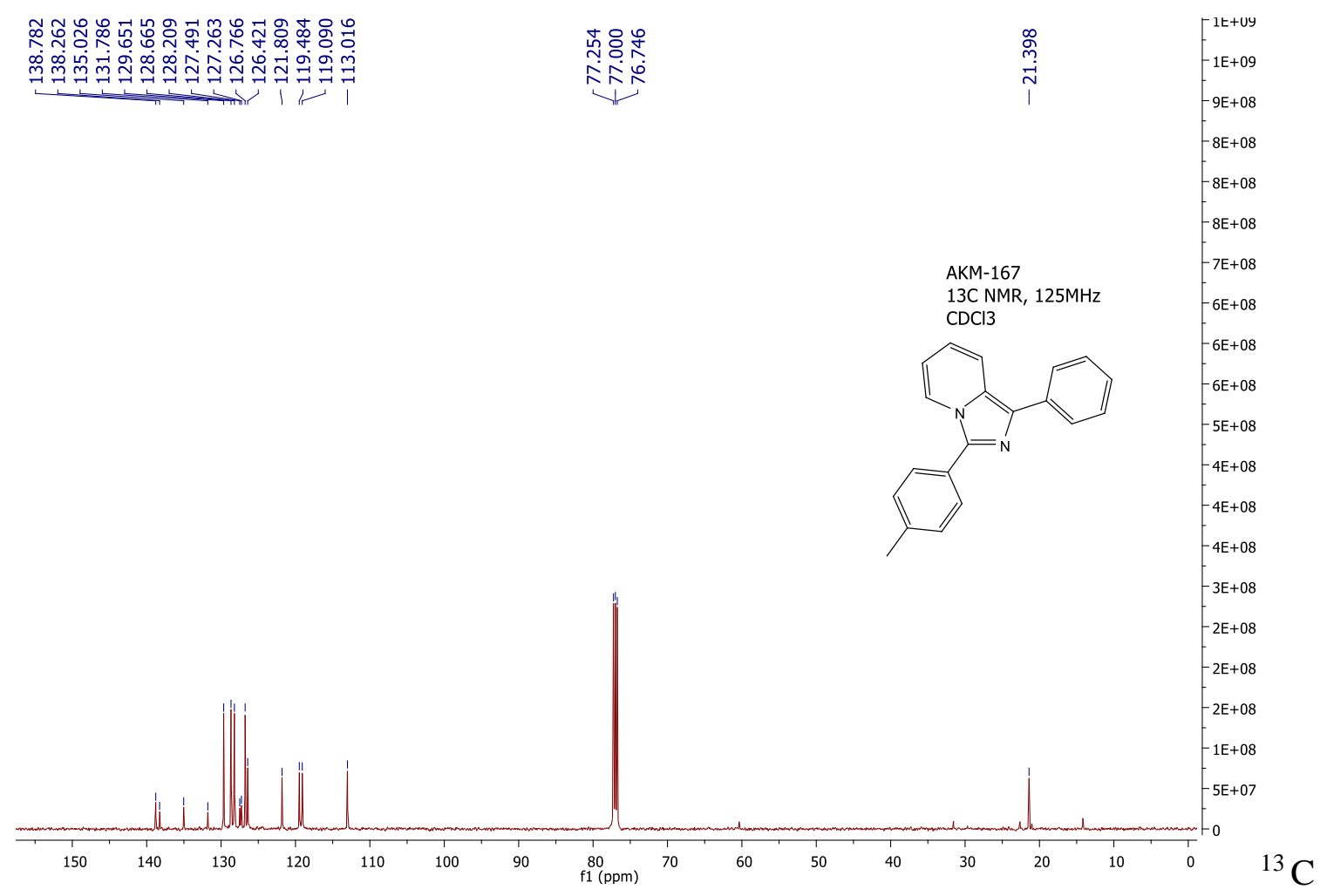

NMR of $\mathbf{3 b}$ 


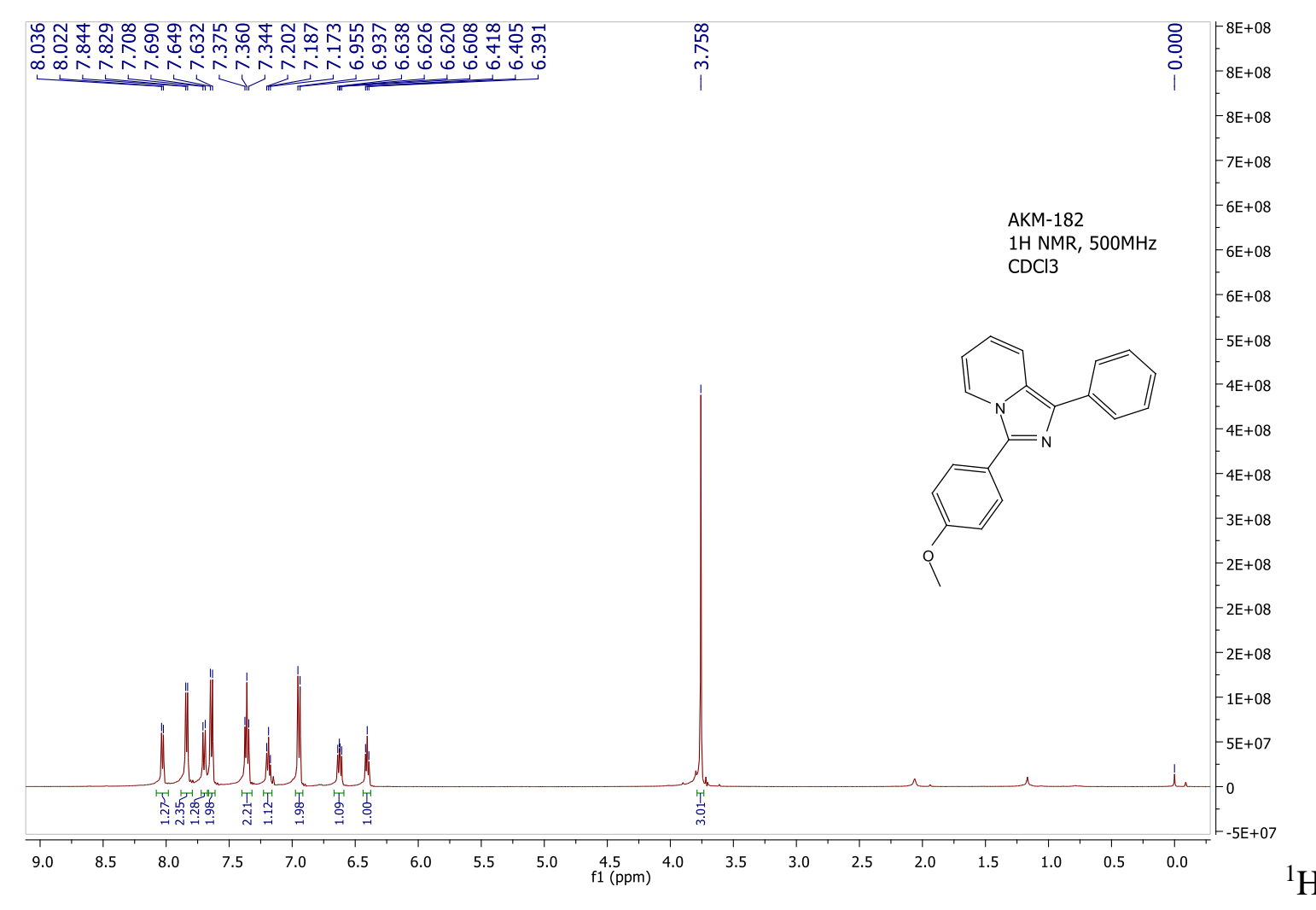

NMR of 3c

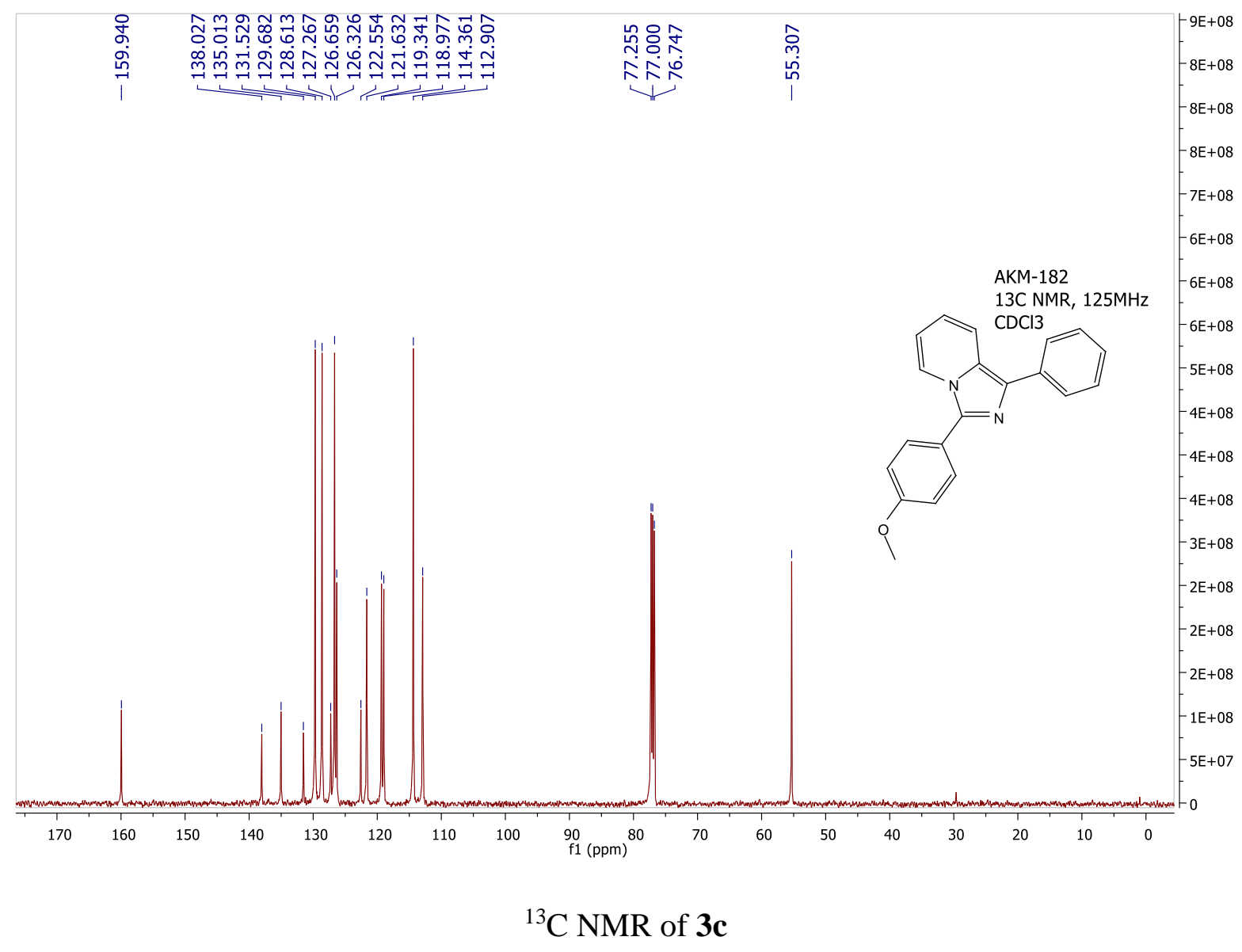




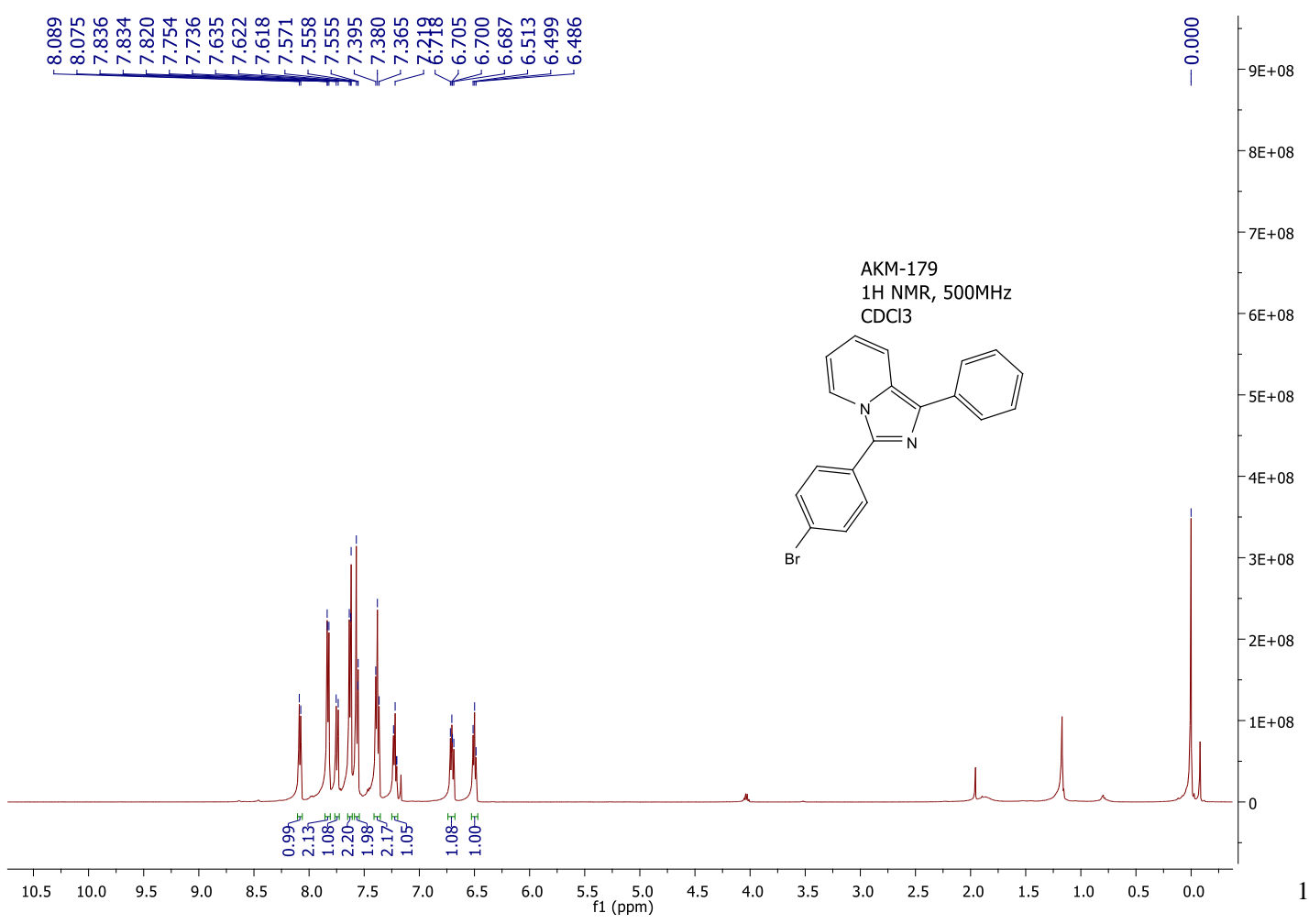

${ }^{1} \mathrm{H}$ NMR

of $\mathbf{3 d}$

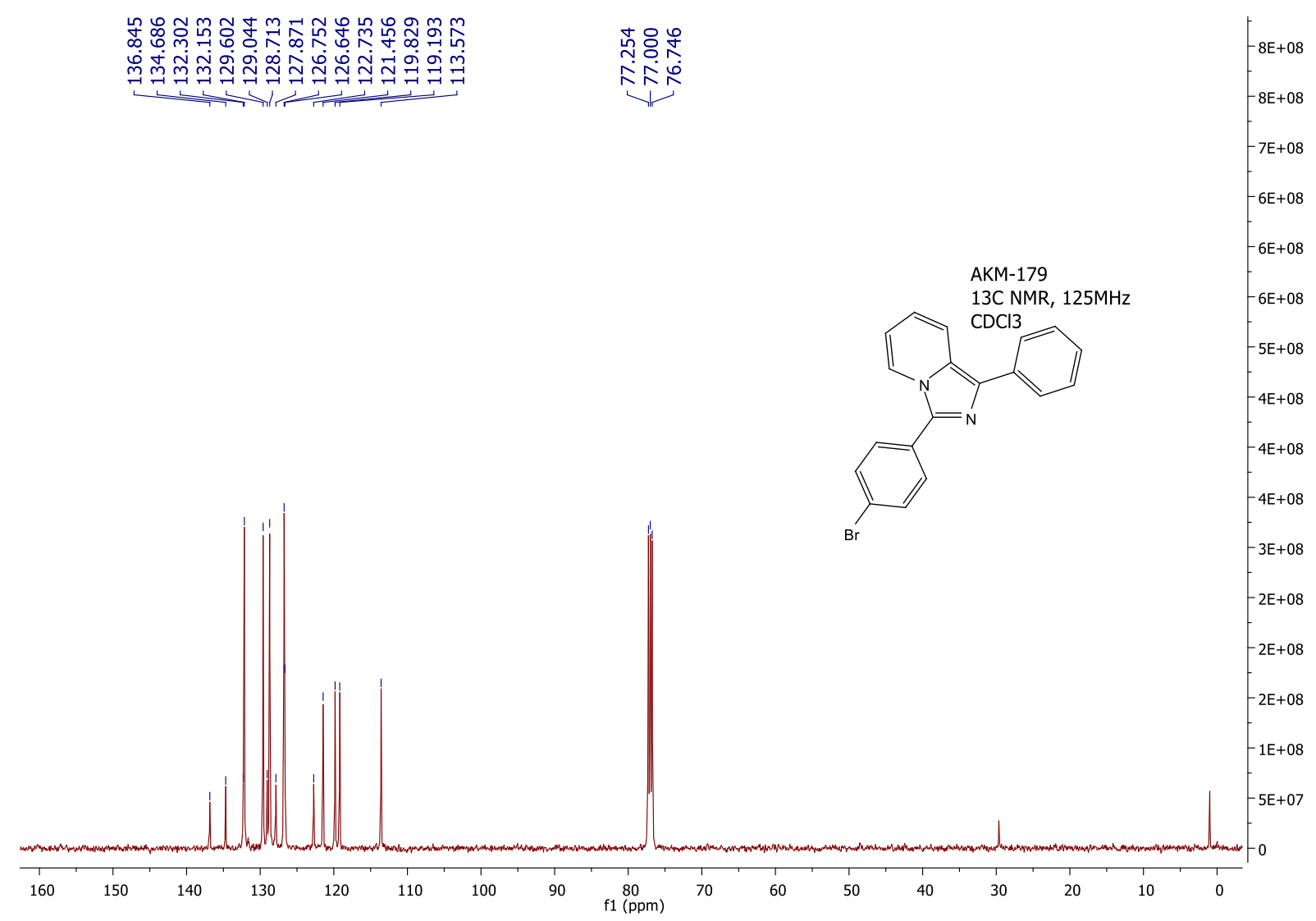

${ }^{13} \mathrm{C}$ NMR of $\mathbf{3 d}$ 


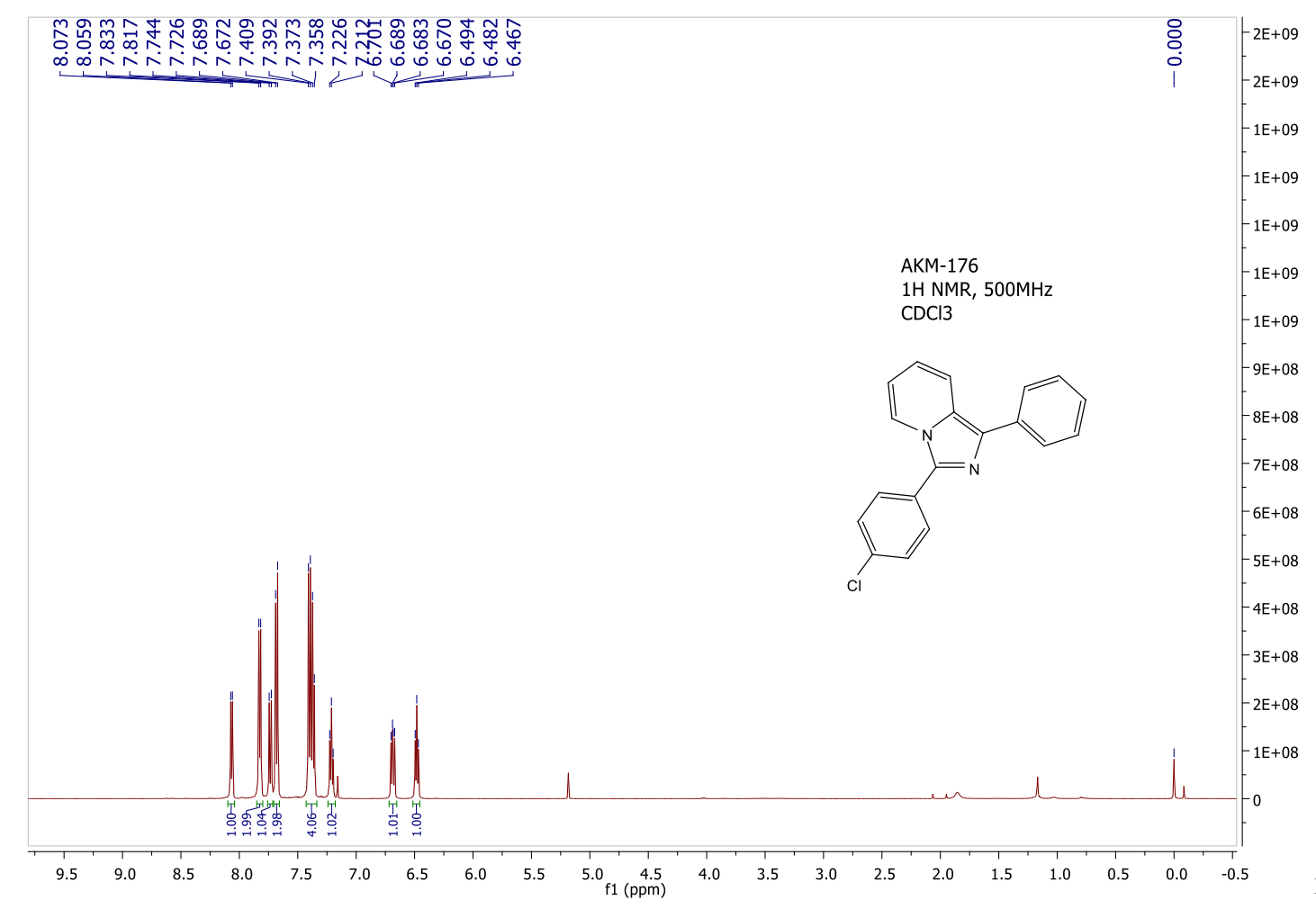

\section{NMR of $\mathbf{3 e}$}

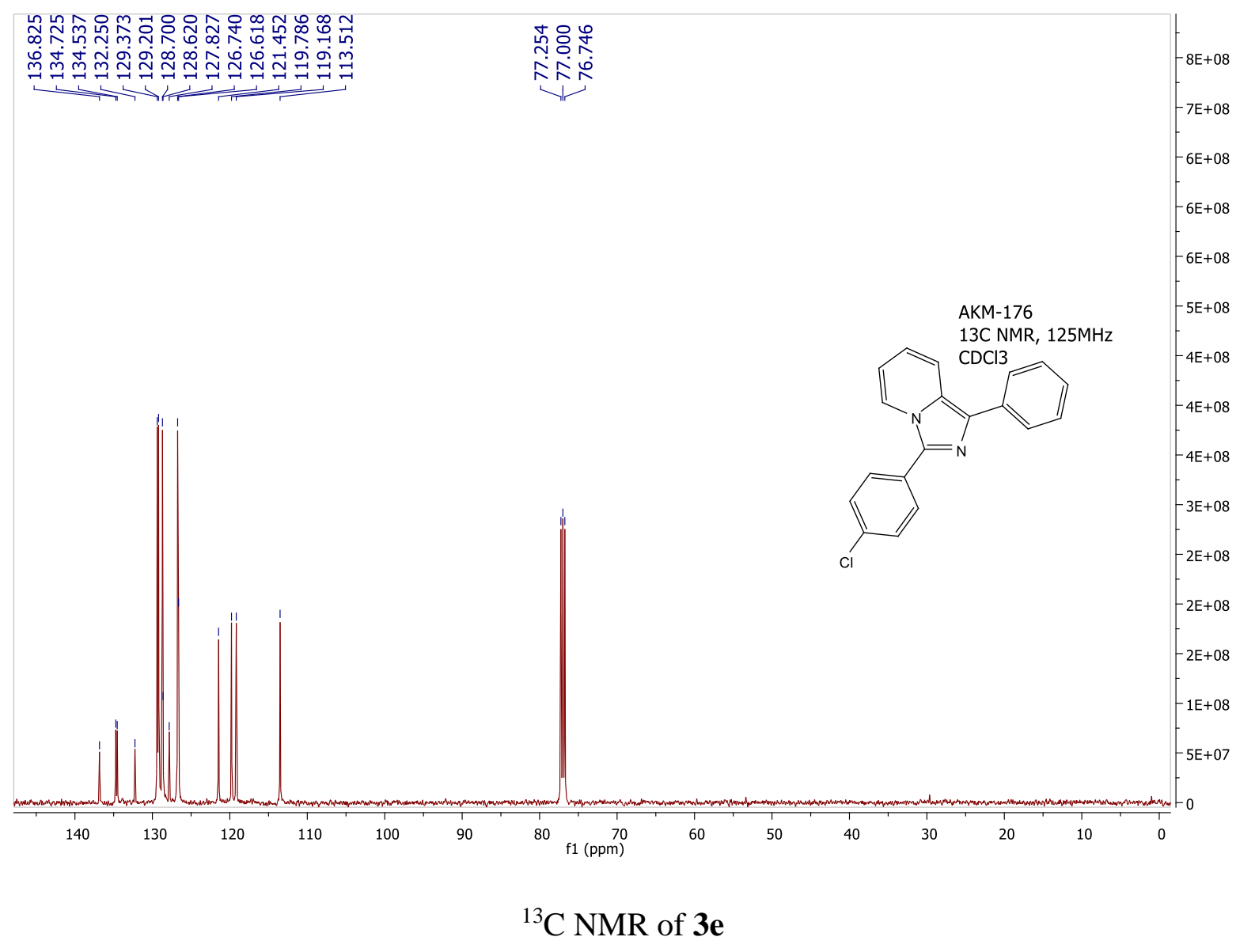




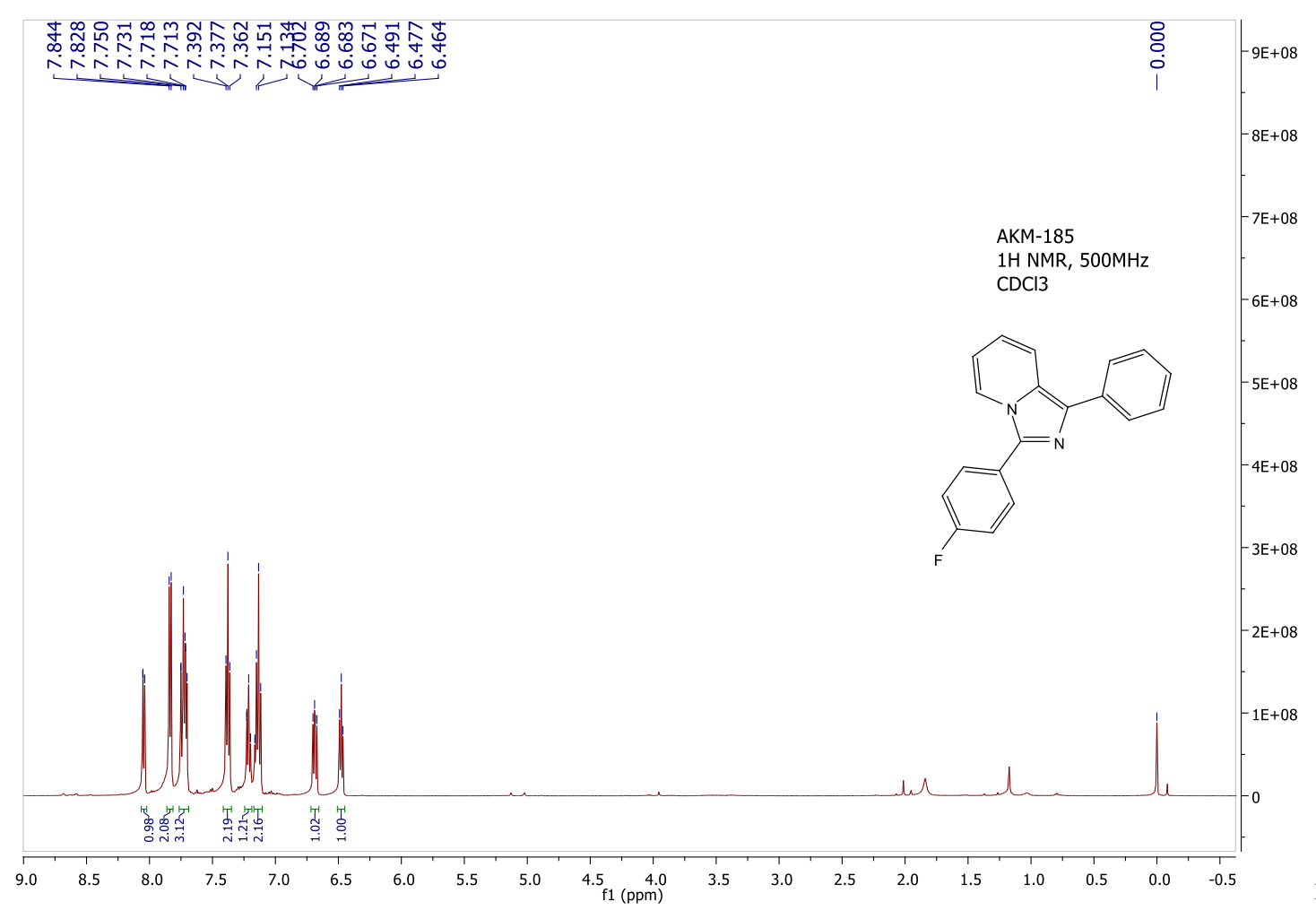

NMR of $\mathbf{3 f}$

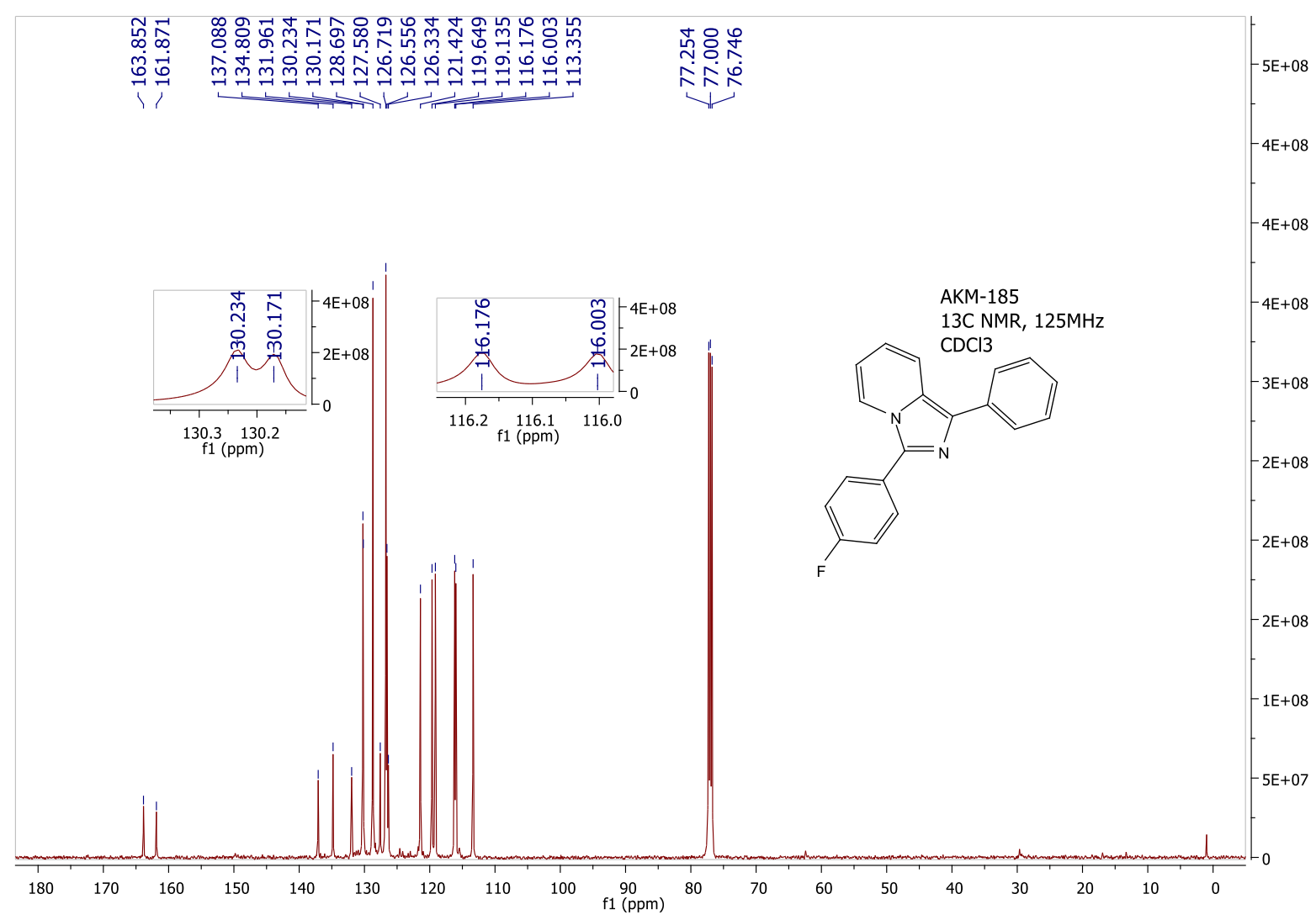

${ }^{13} \mathrm{C}$ NMR of $\mathbf{3 f}$ 


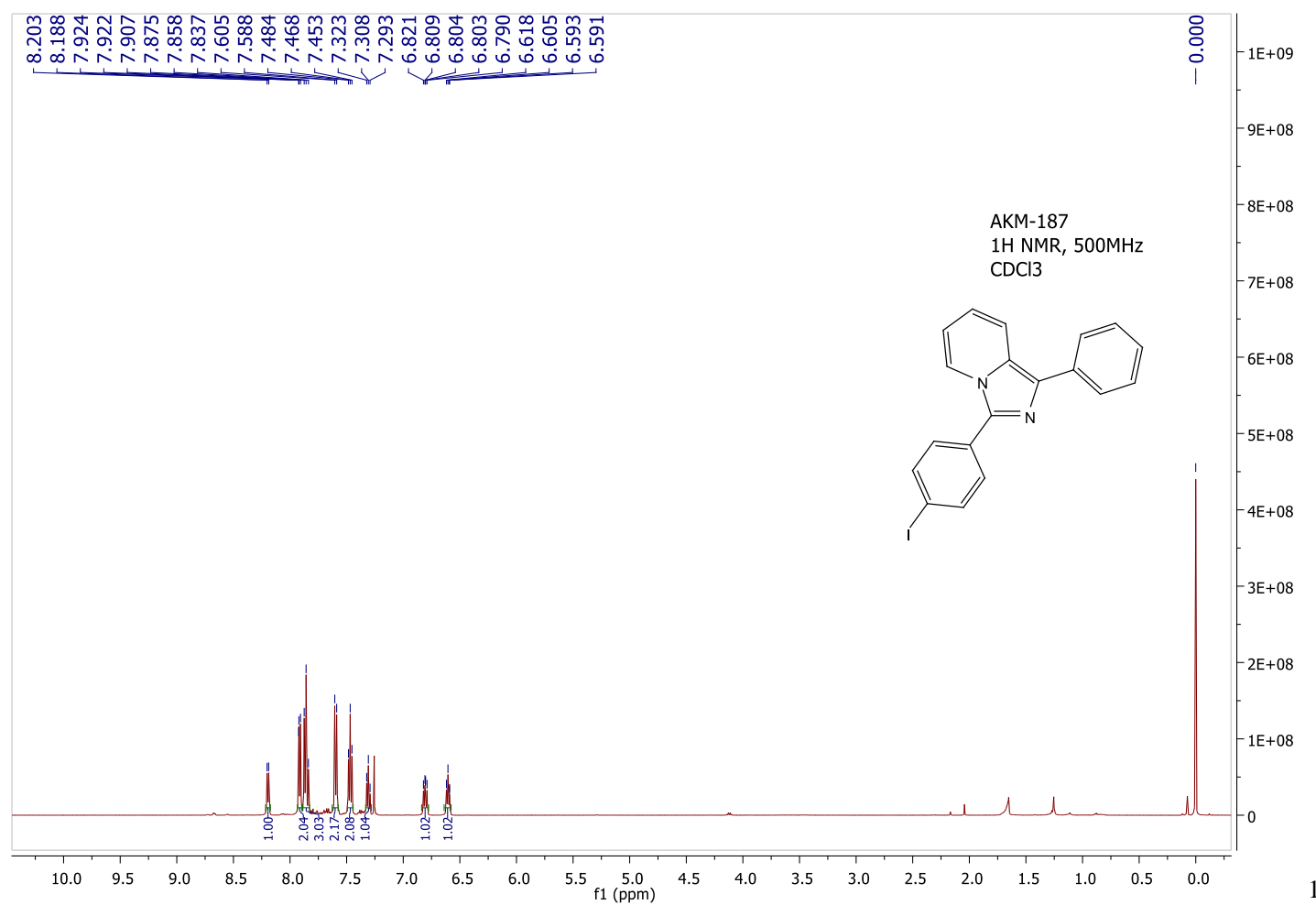

${ }^{1} \mathrm{H}$

\section{NMR of $\mathbf{3 g}$}

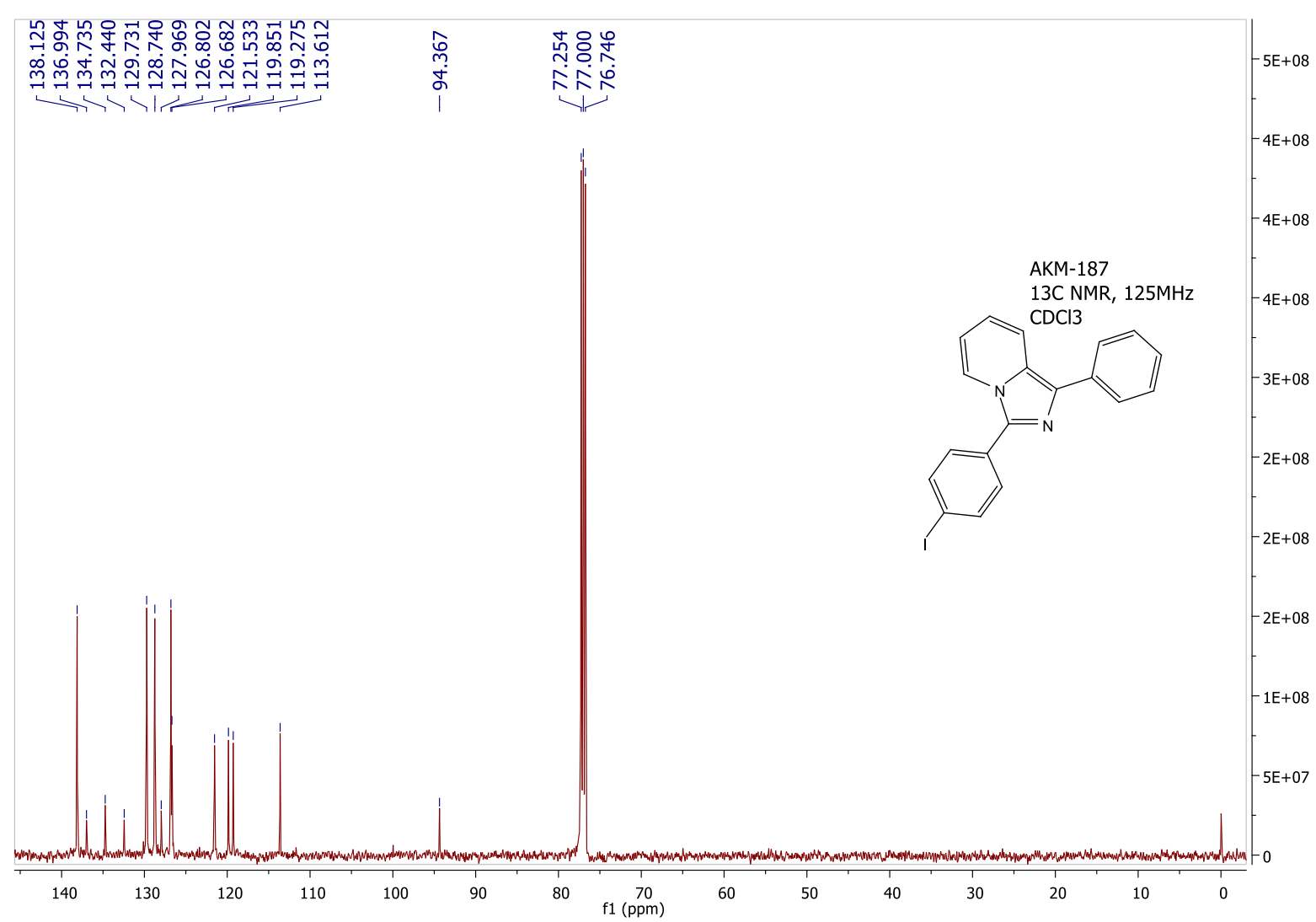

${ }^{13} \mathrm{C}$ NMR of $\mathbf{3 g}$ 


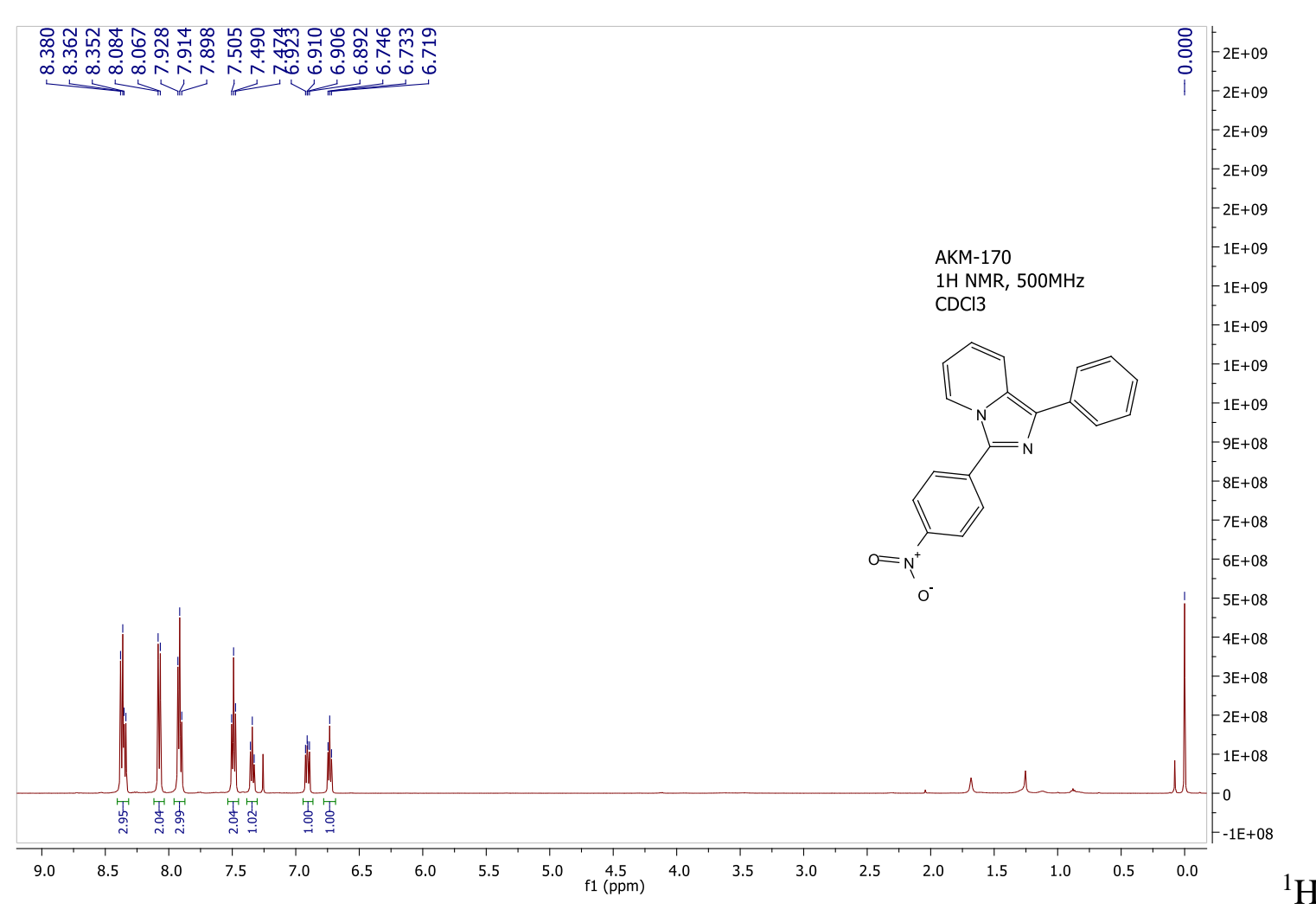

\section{NMR of $\mathbf{3 h}$}

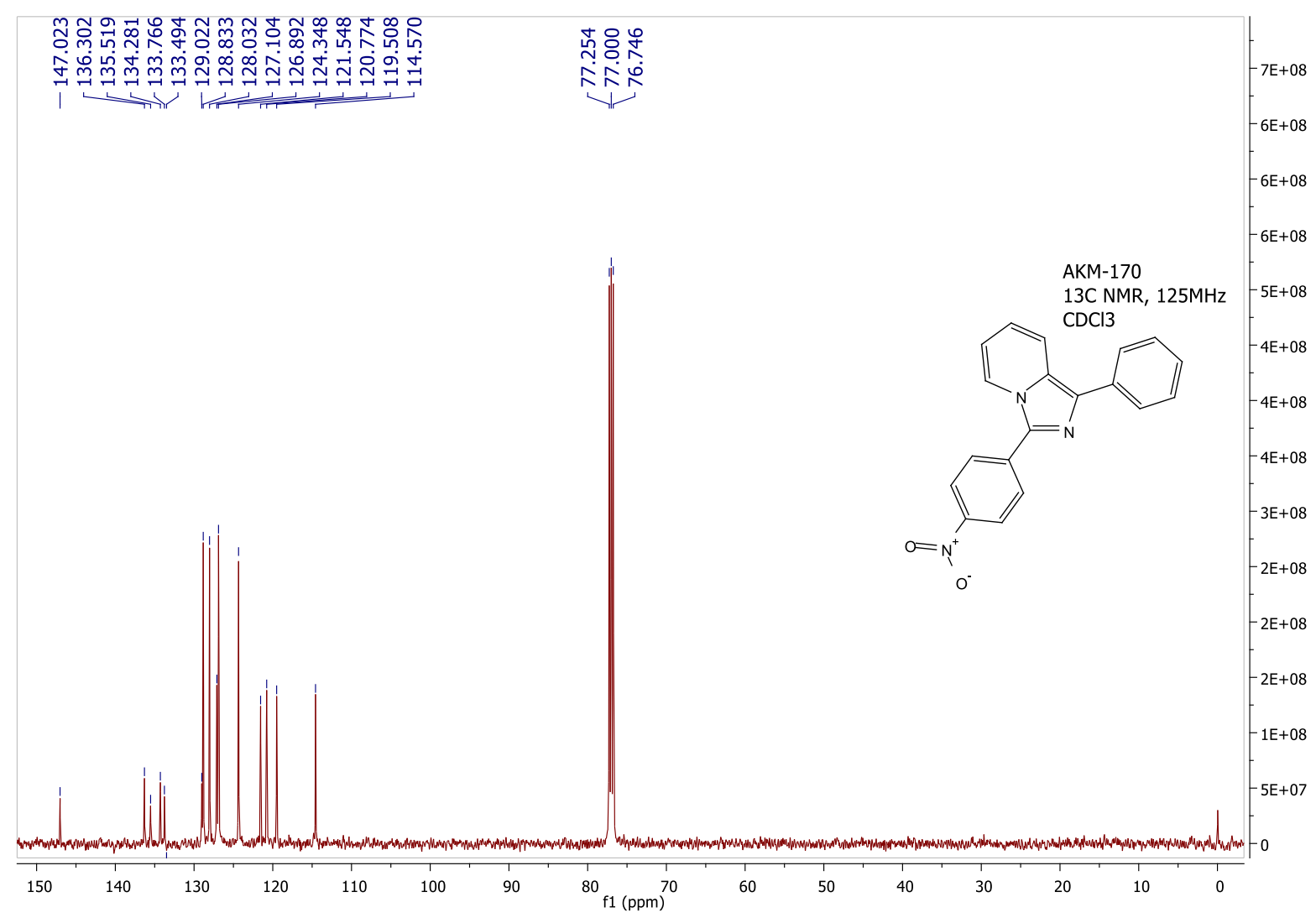

${ }^{13} \mathrm{C}$ NMR of $\mathbf{3 h}$ 


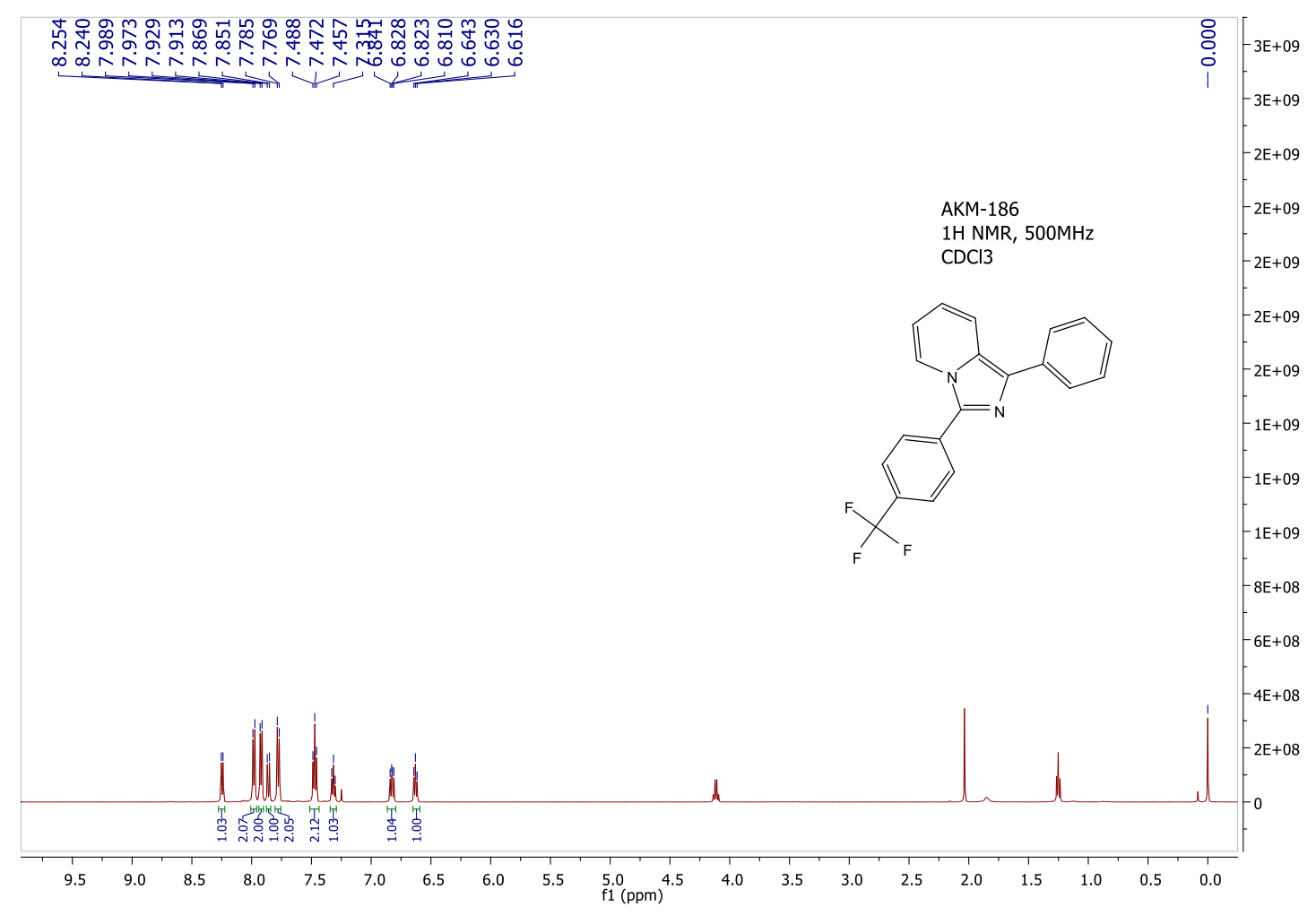

NMR of $\mathbf{3 i}$

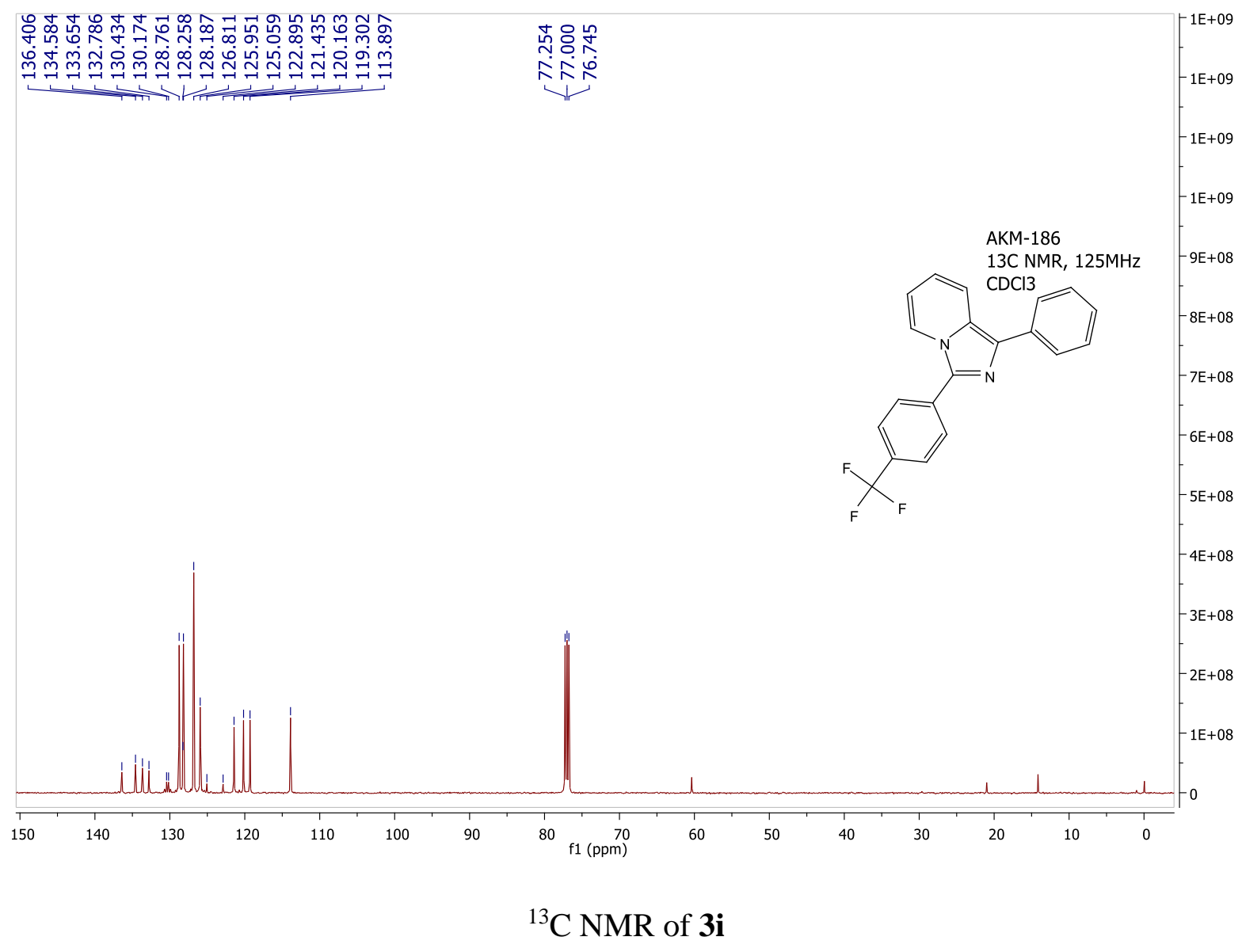




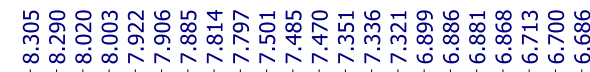

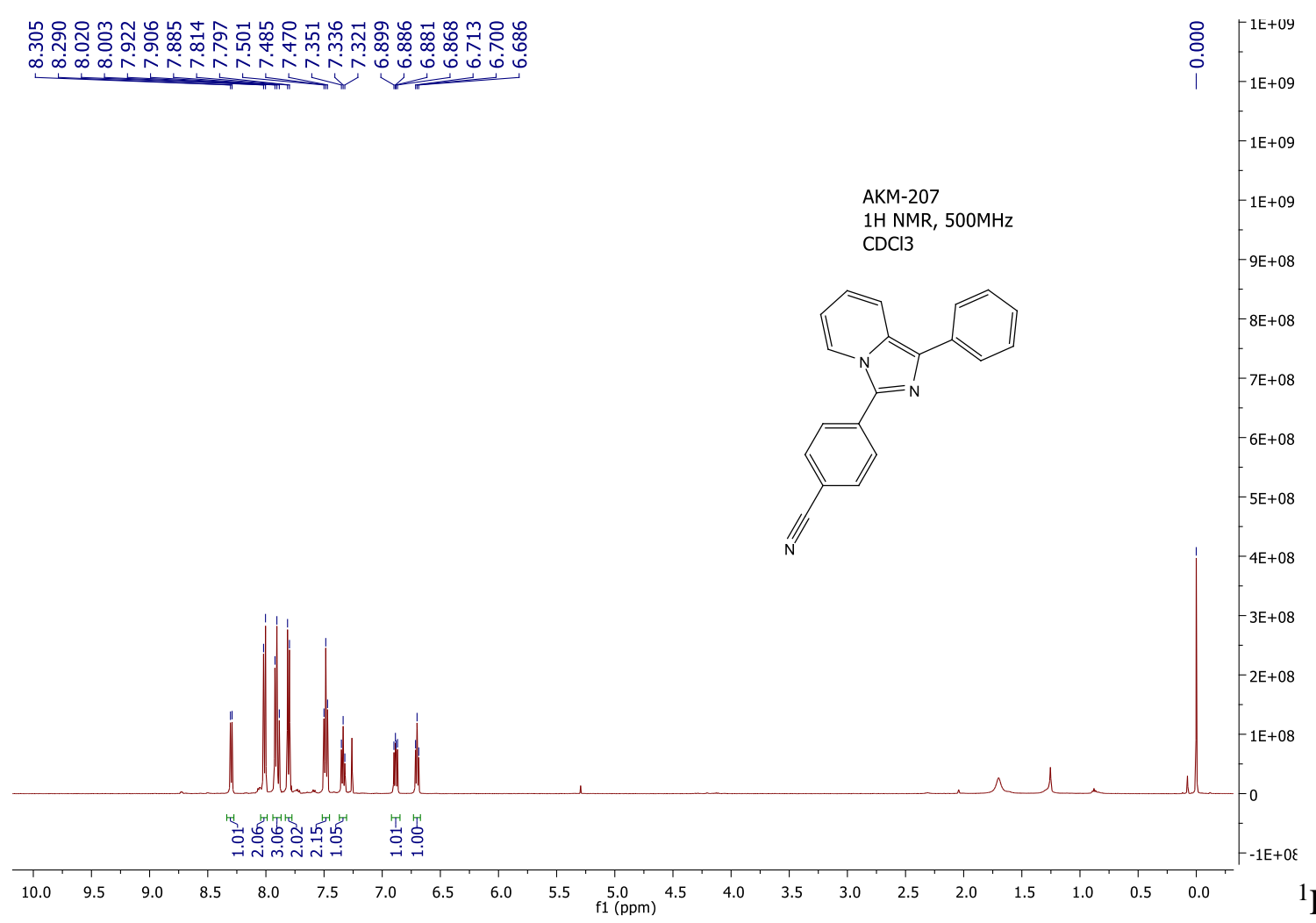

${ }^{1} \mathrm{H}$

\section{NMR of $\mathbf{3 j}$}

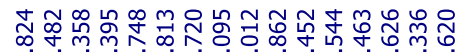

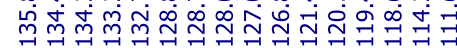

耑吕尔

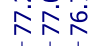

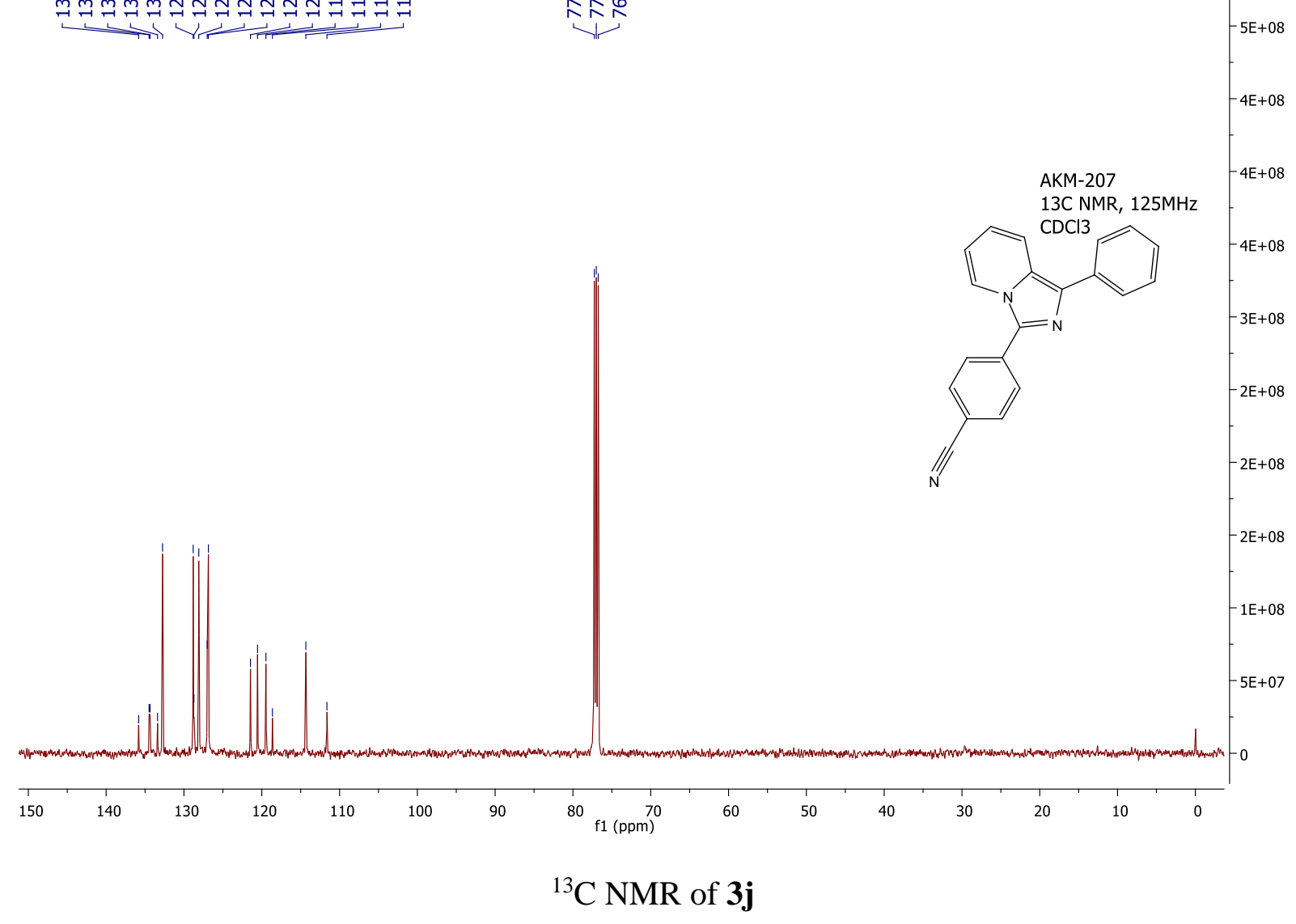




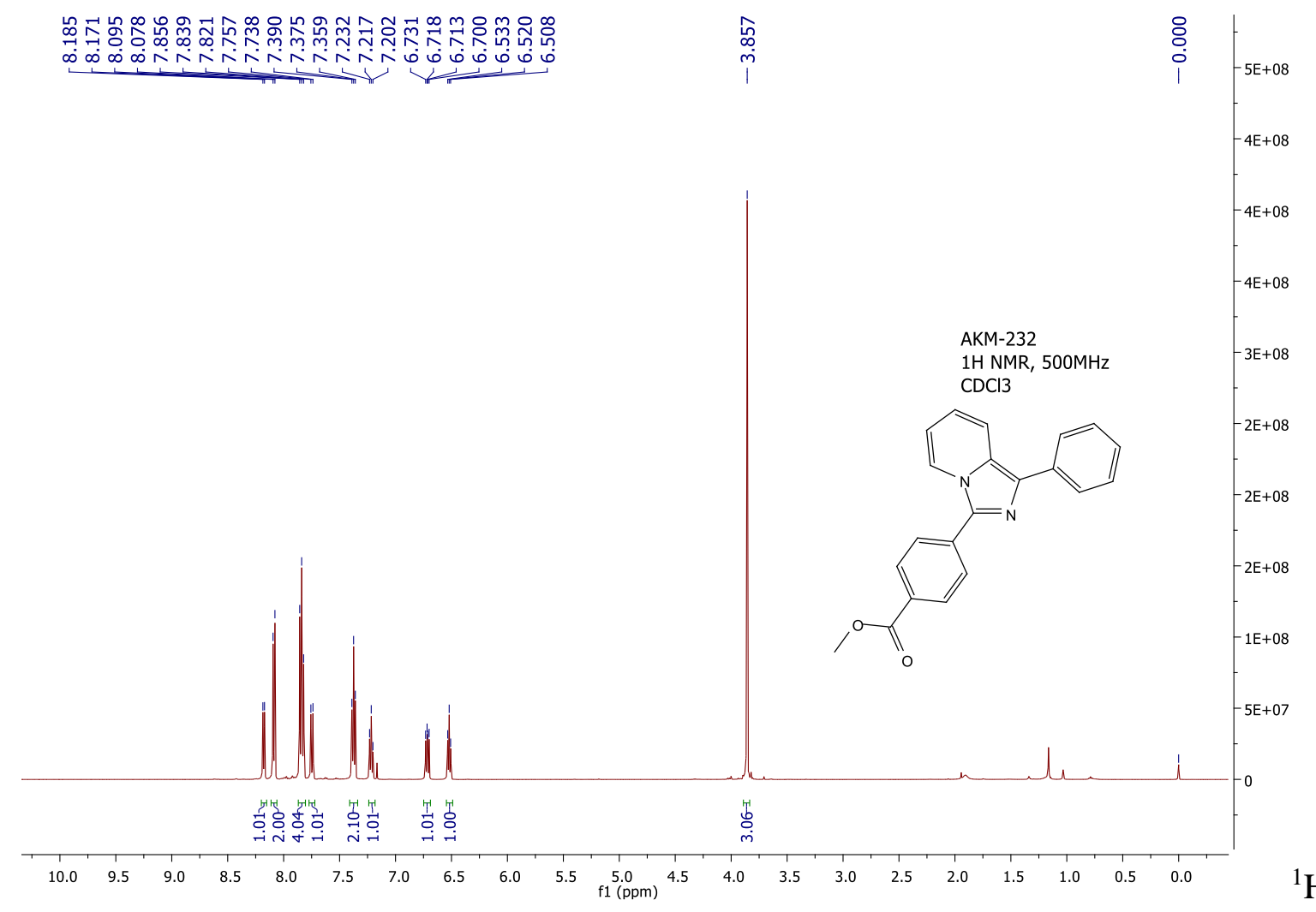

$\mathrm{H}$

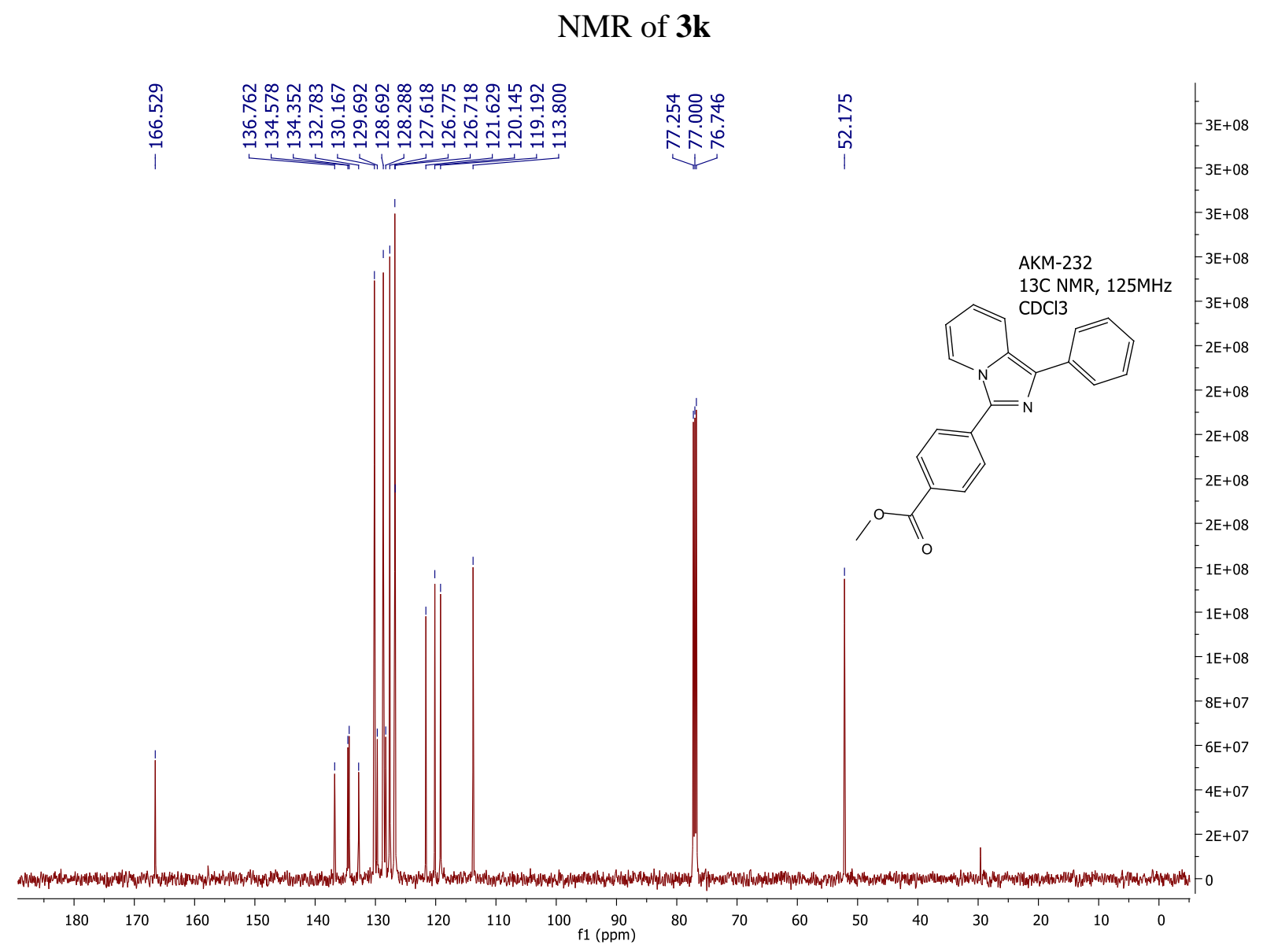

${ }^{13} \mathrm{C}$ NMR of $3 k$ 


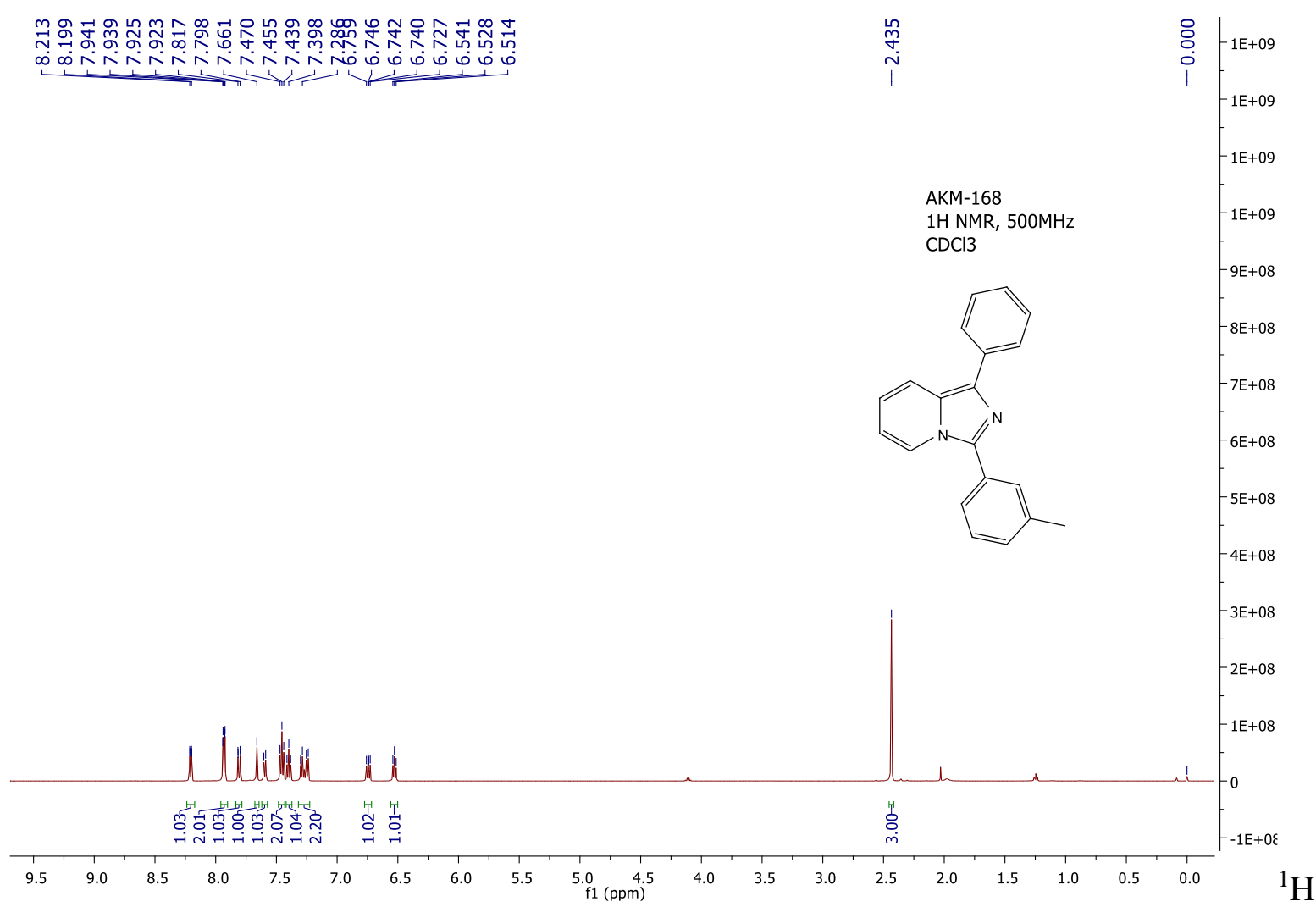

NMR of 31

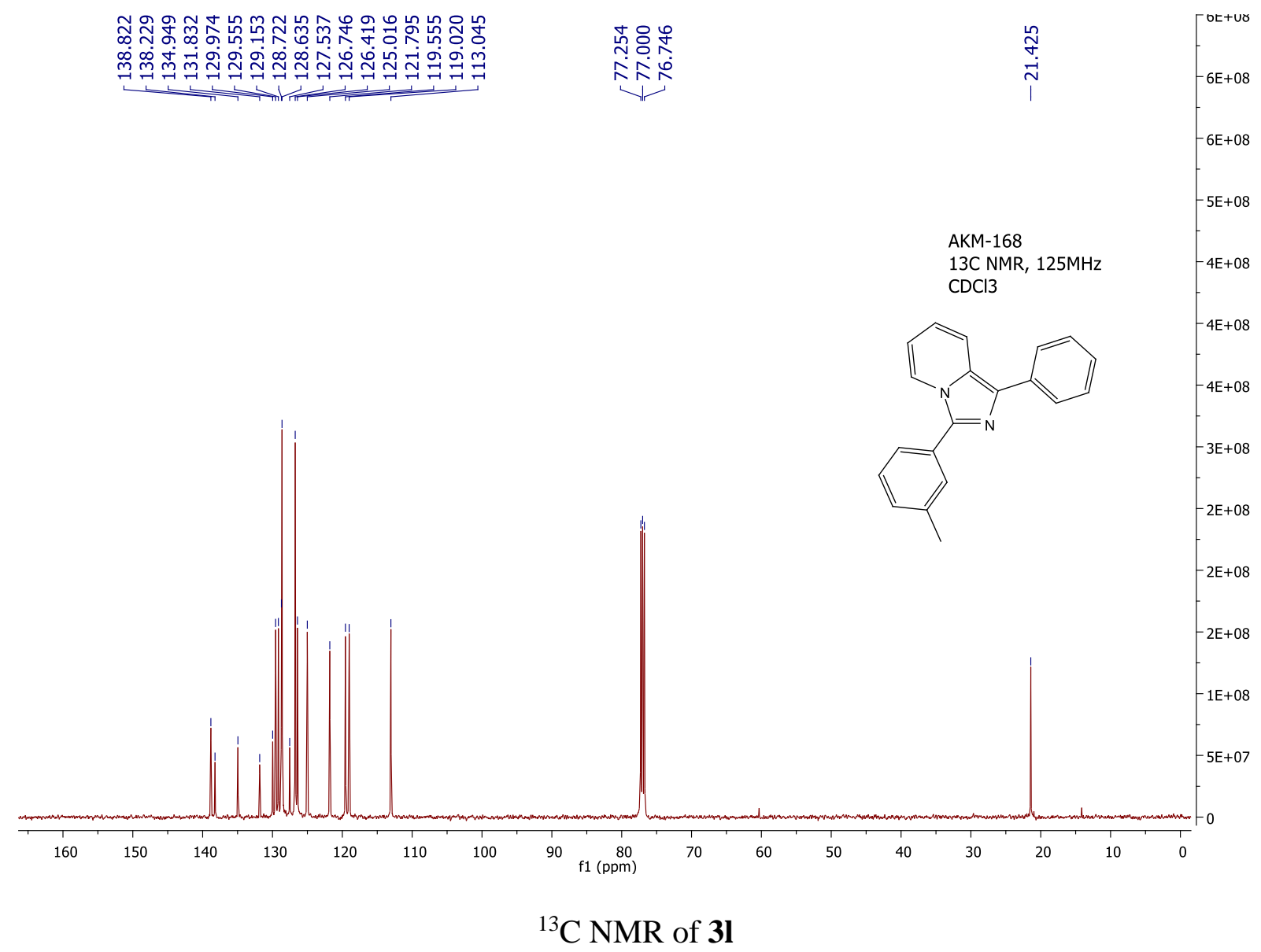




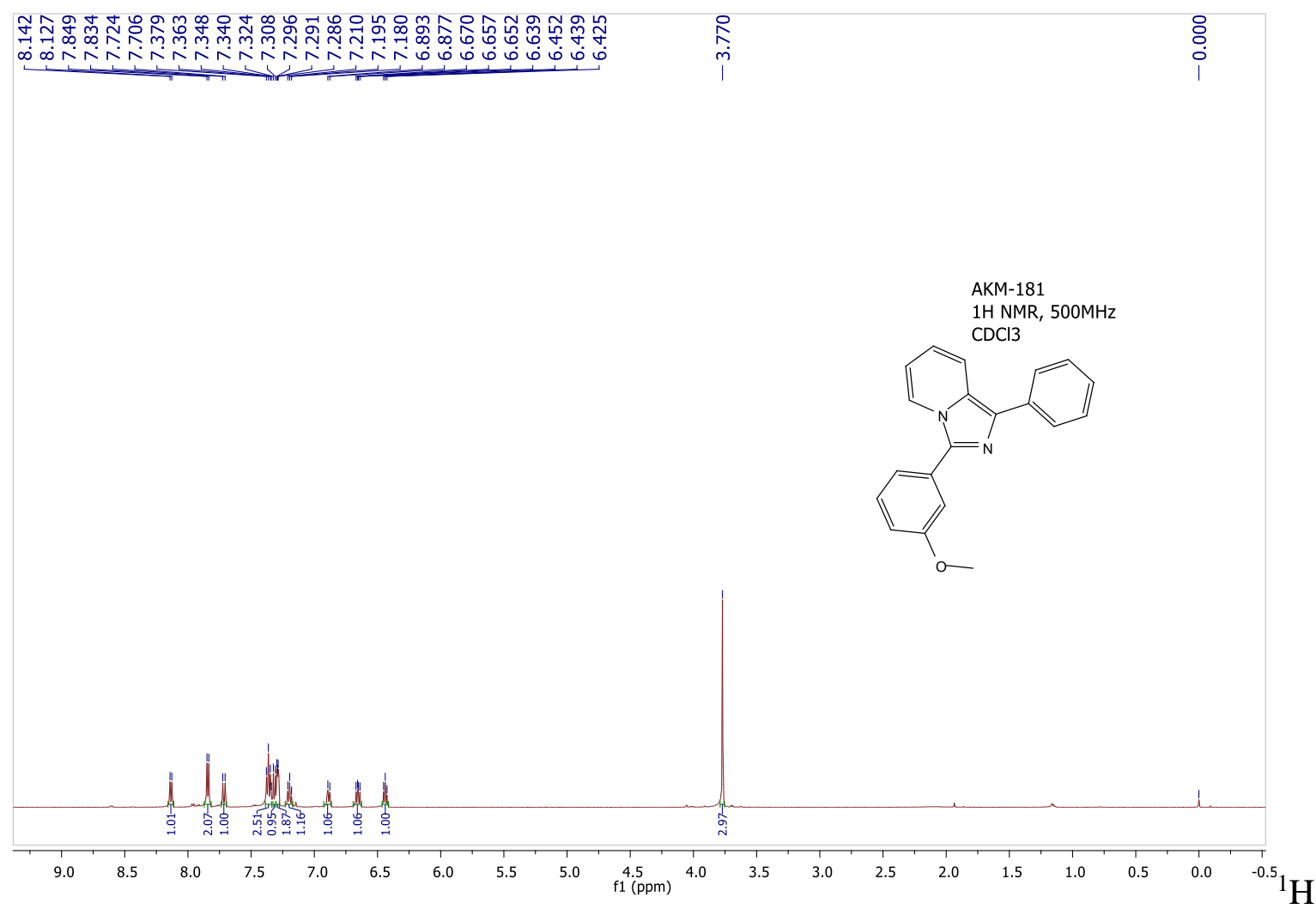

NMR of 3m

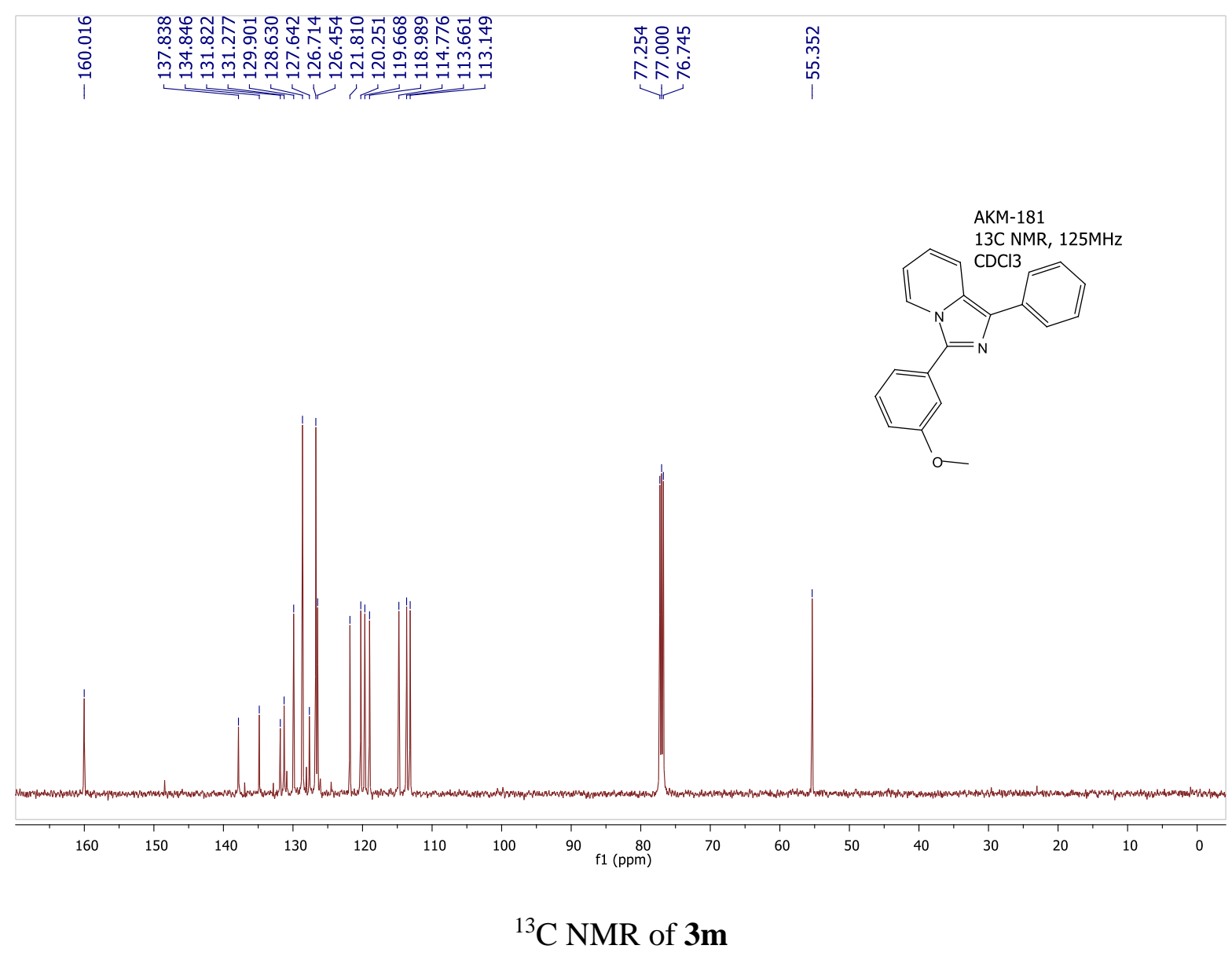




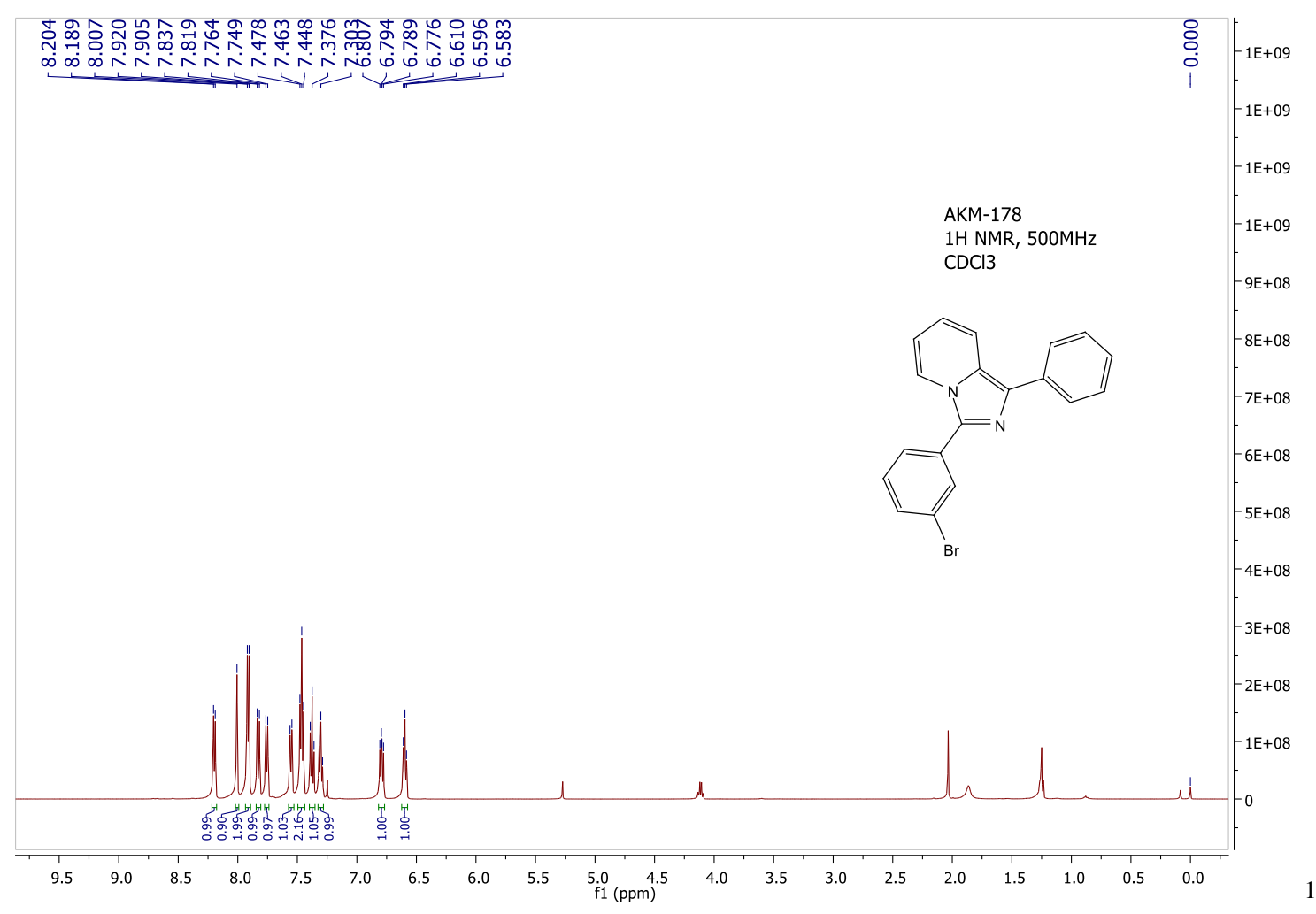

NMR of 3n

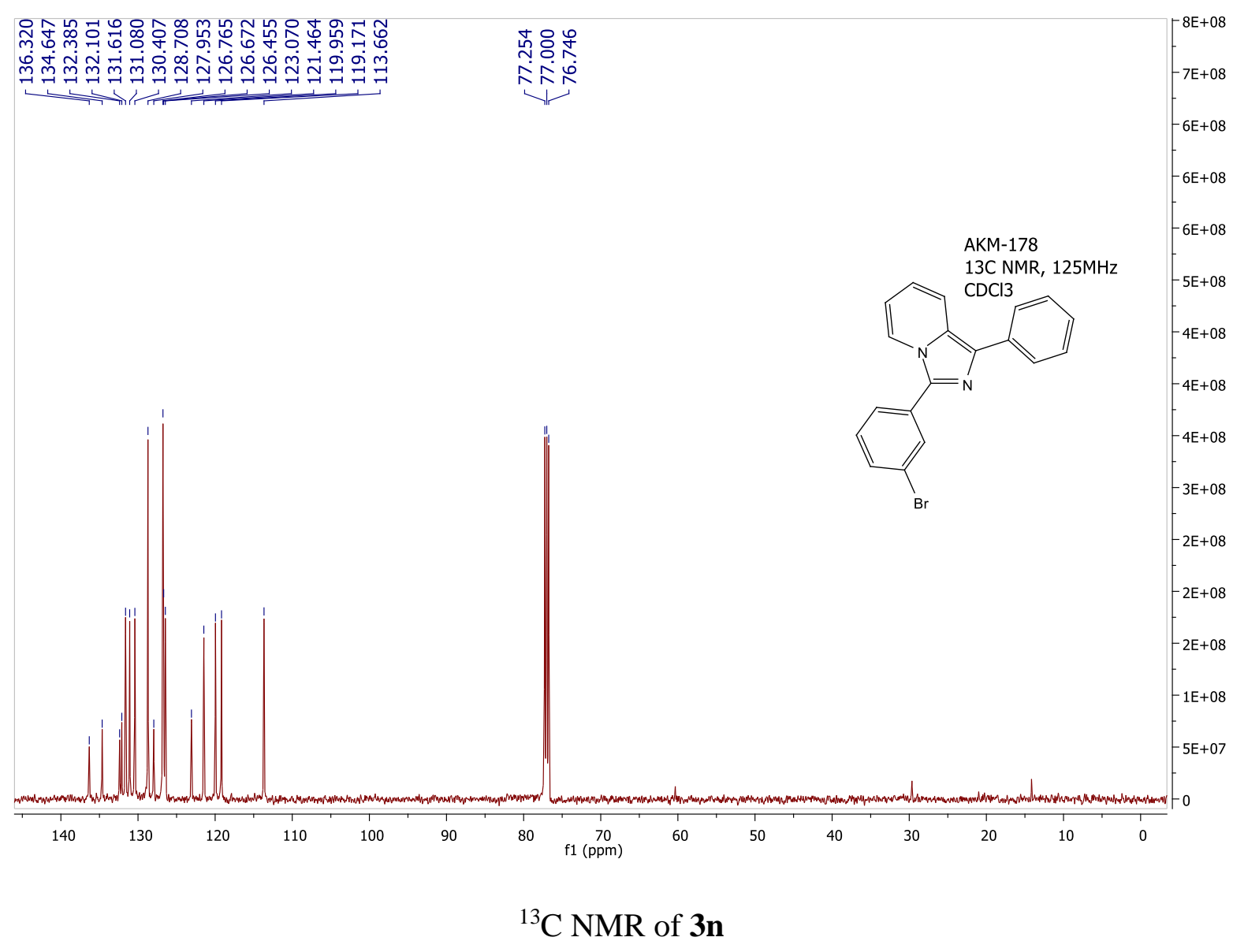




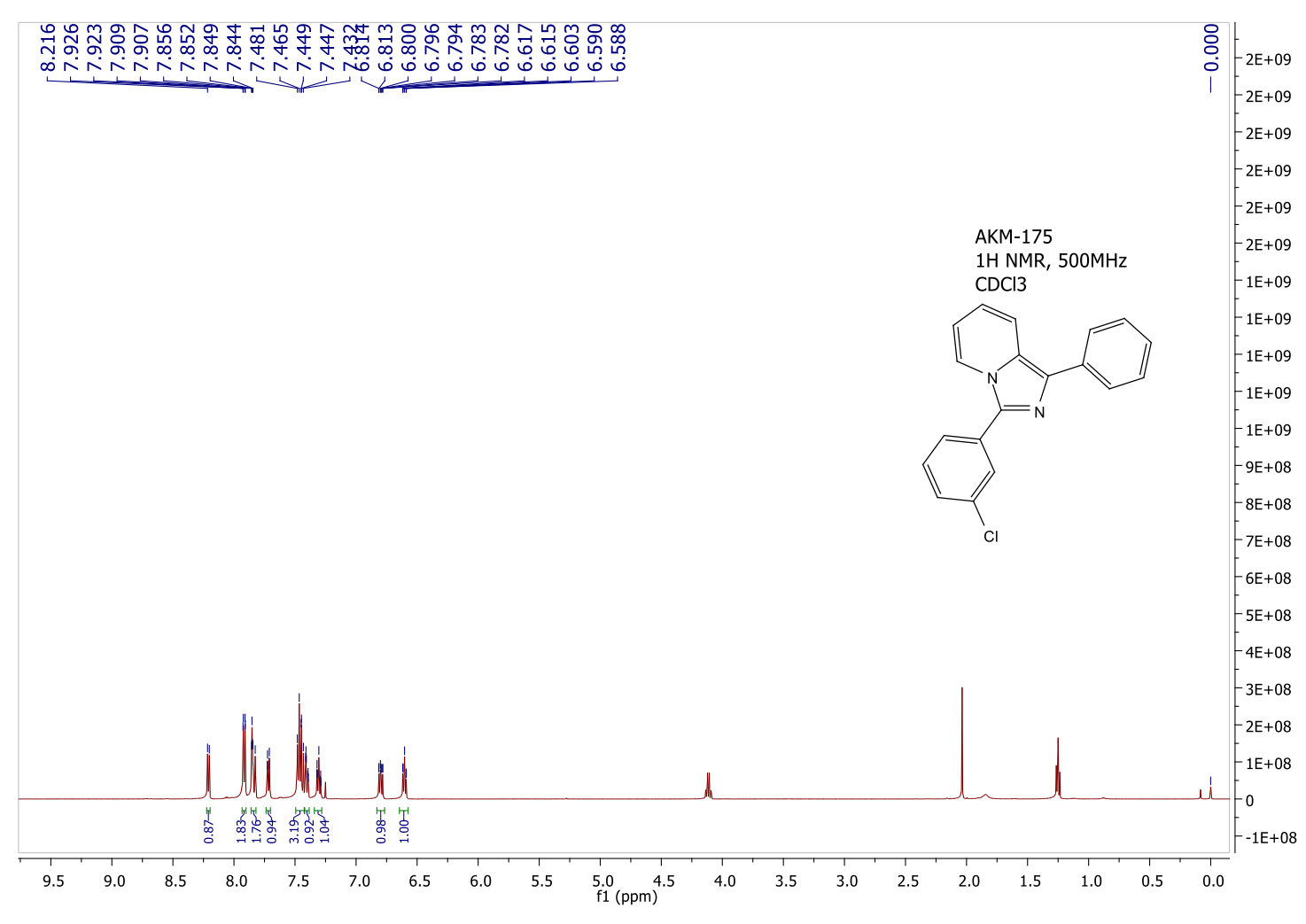

NMR of 30

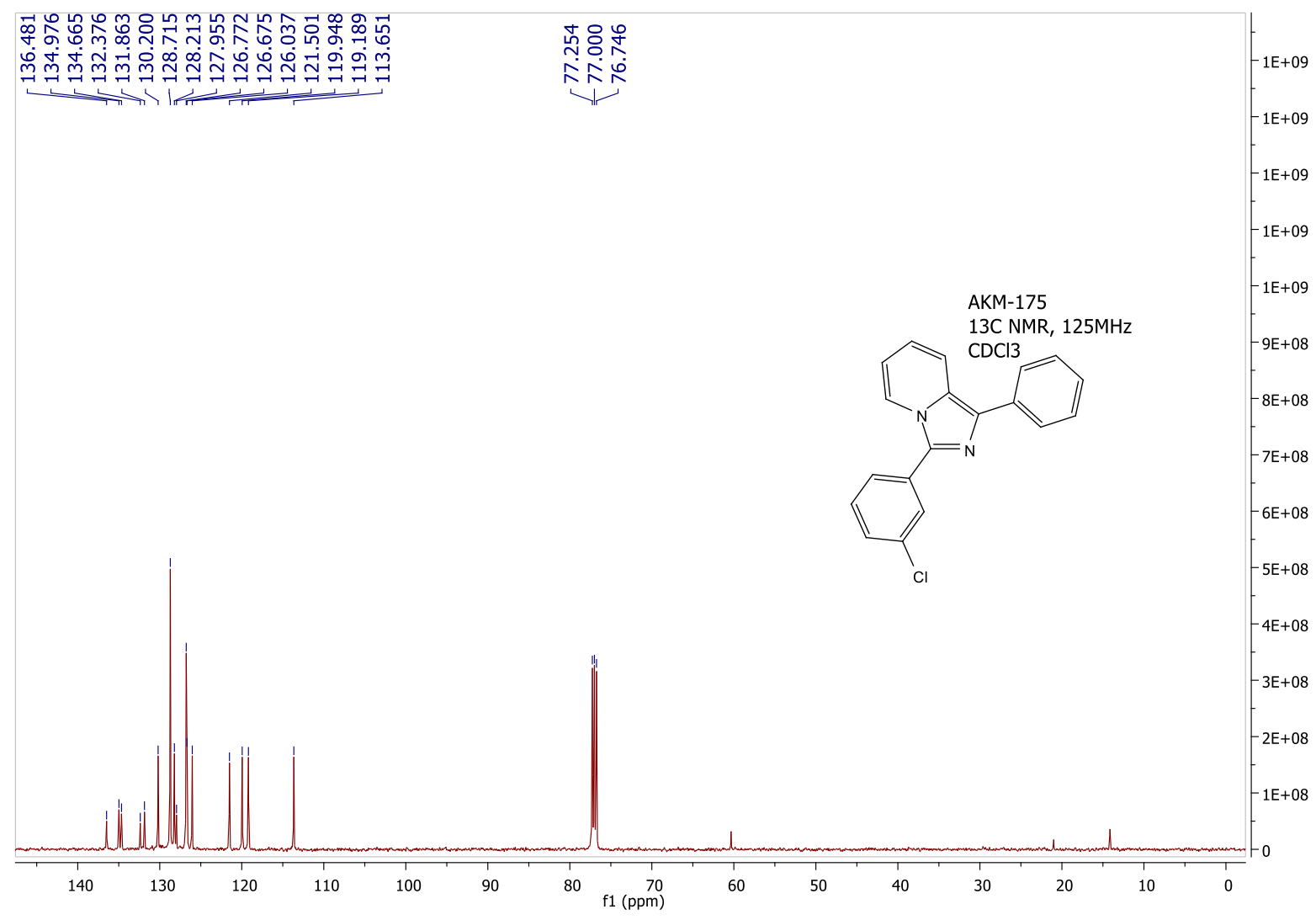

${ }^{13} \mathrm{C}$ NMR of $3 \mathrm{o}$ 


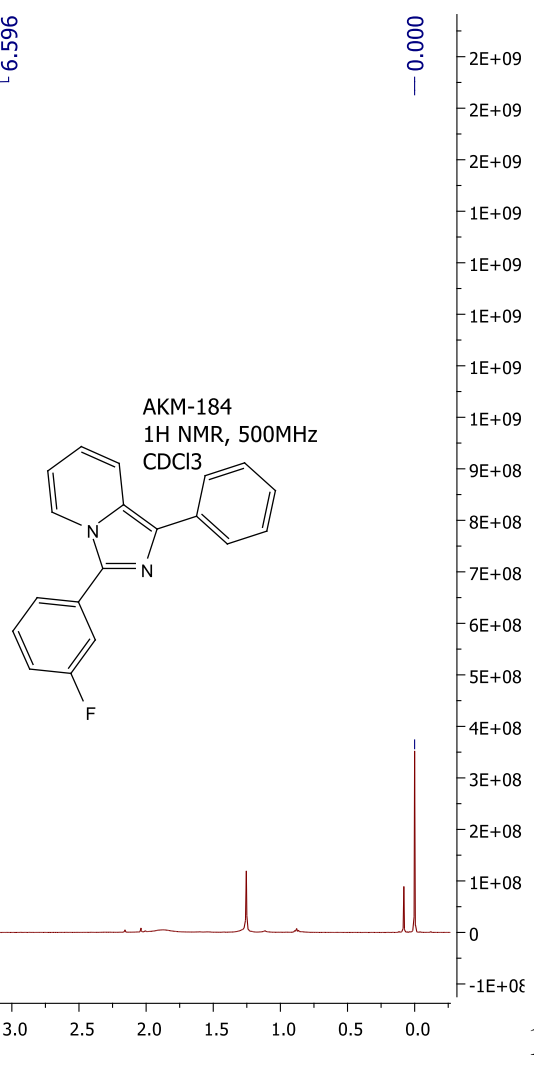

\section{NMR of 3p}

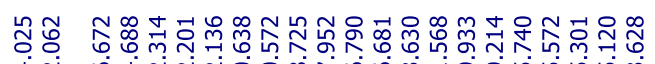

萑过

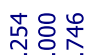

소용

$6 \mathrm{E}+08$

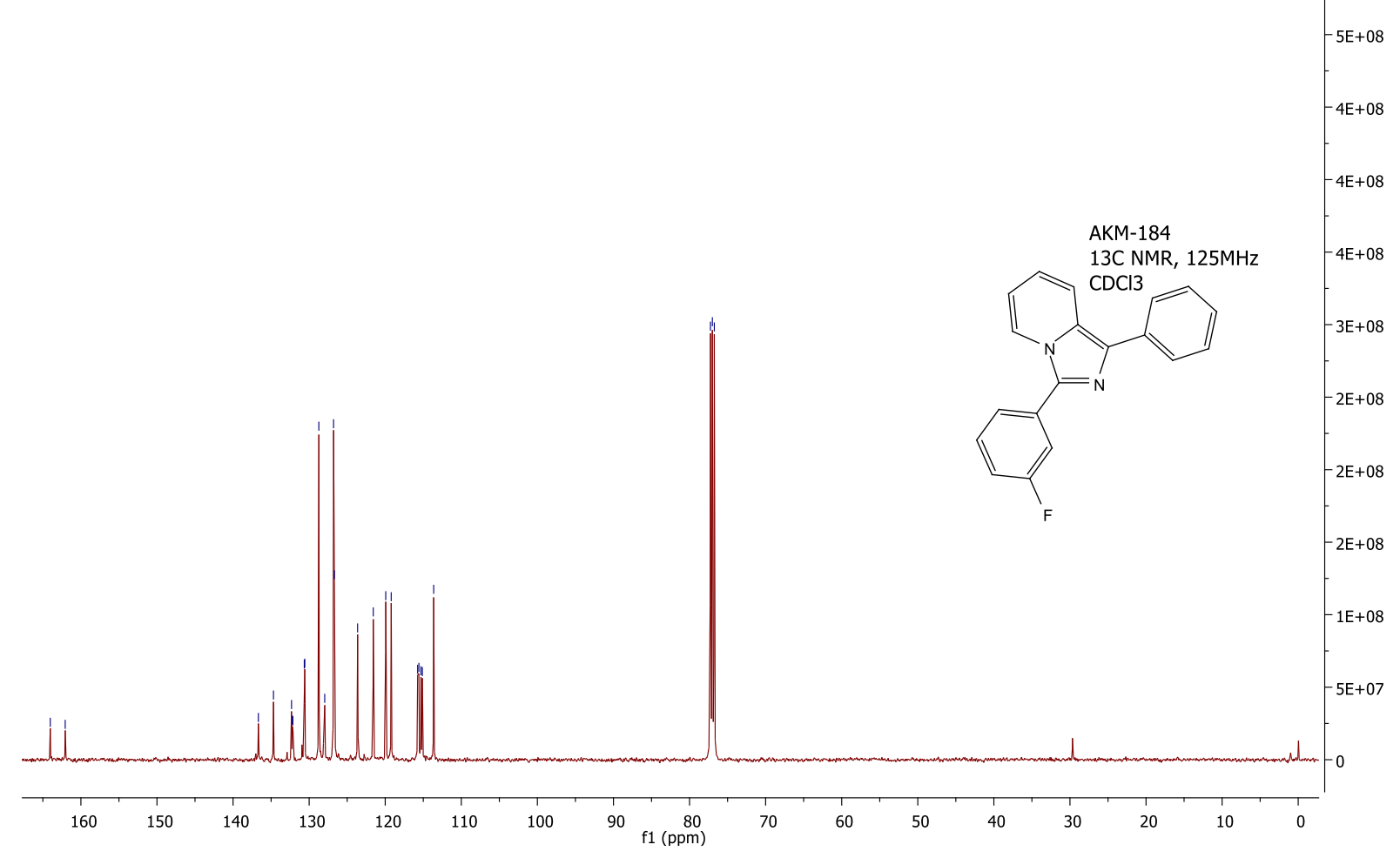

13C NMR of $\mathbf{3 p}$ 


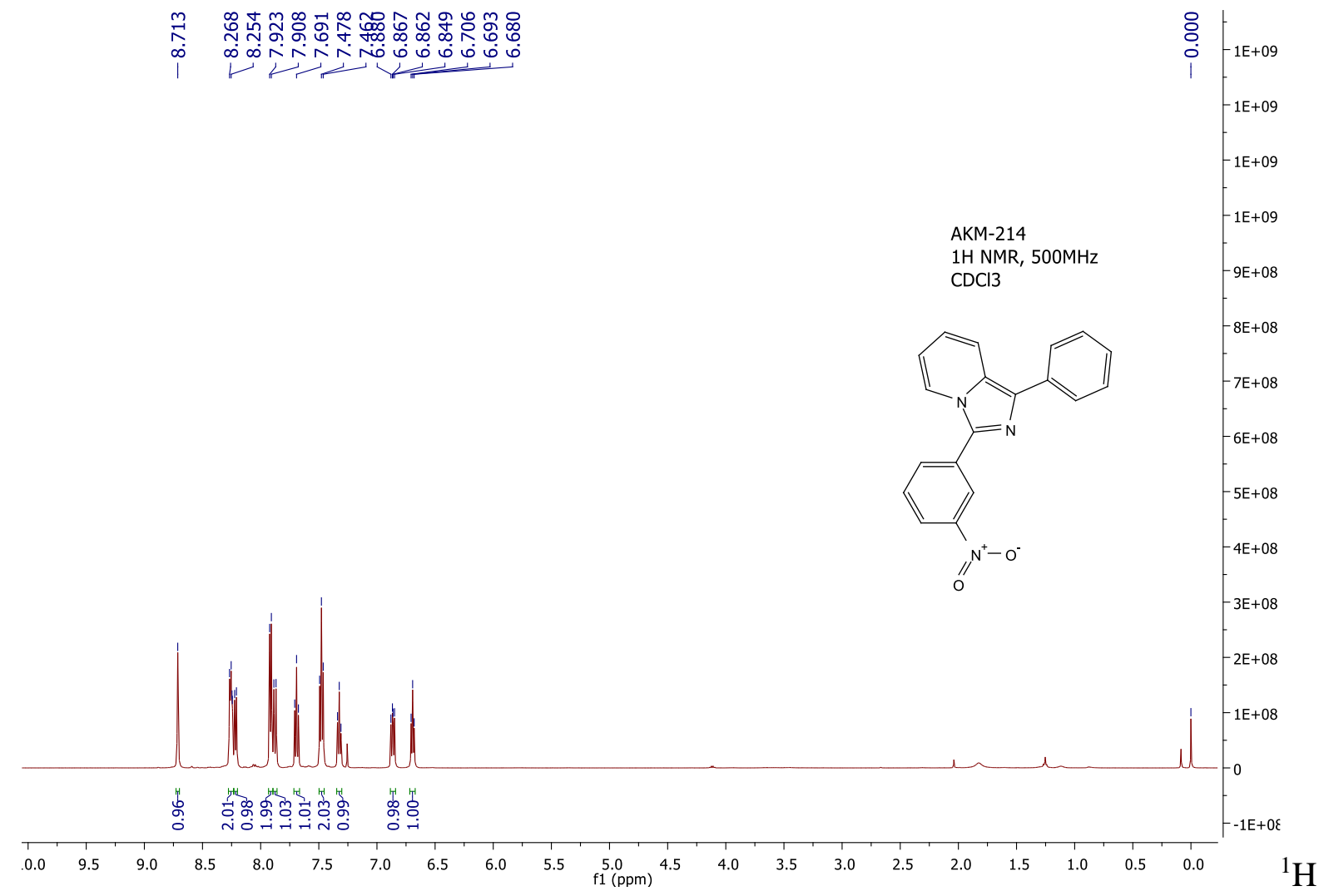

\section{NMR of 3q}

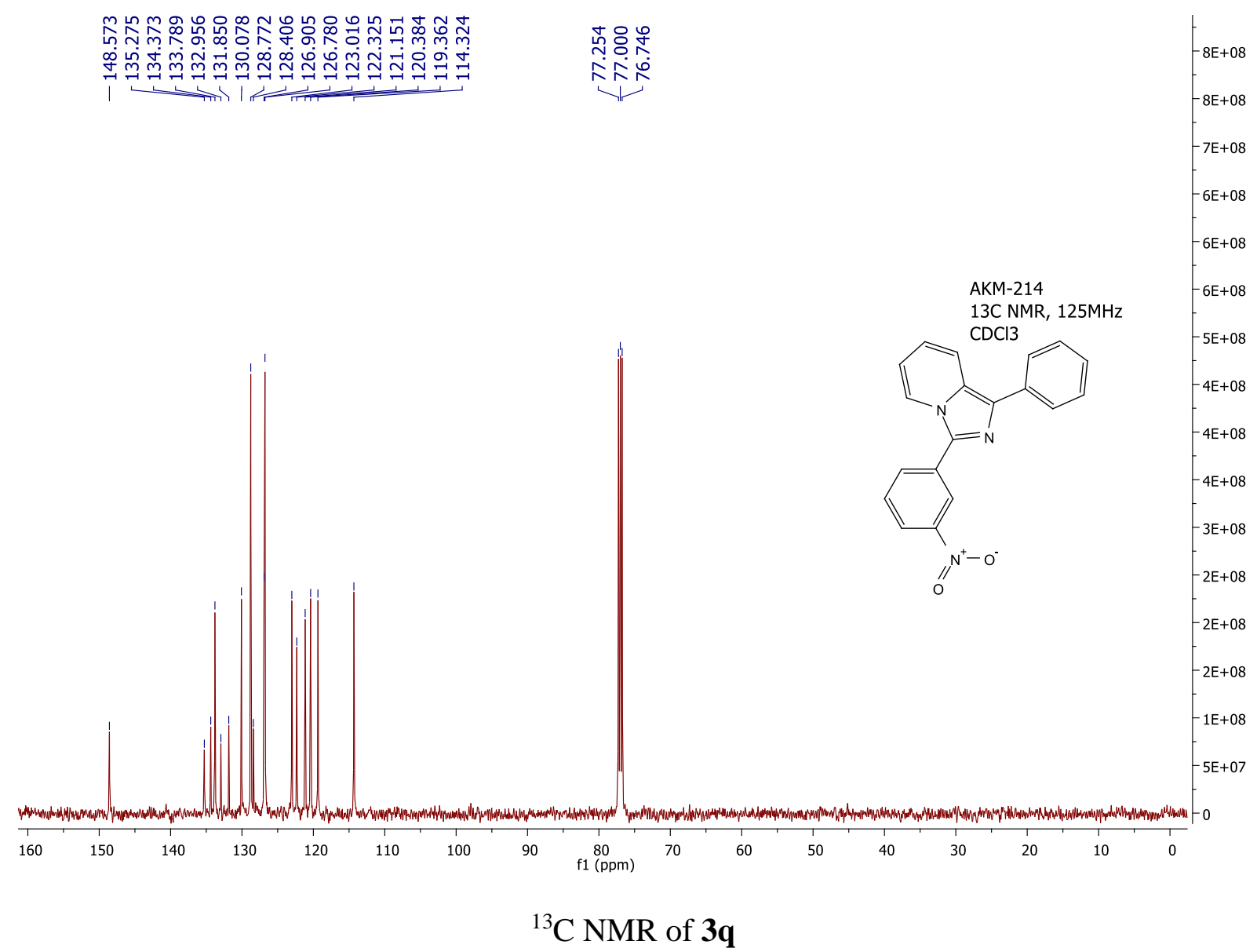




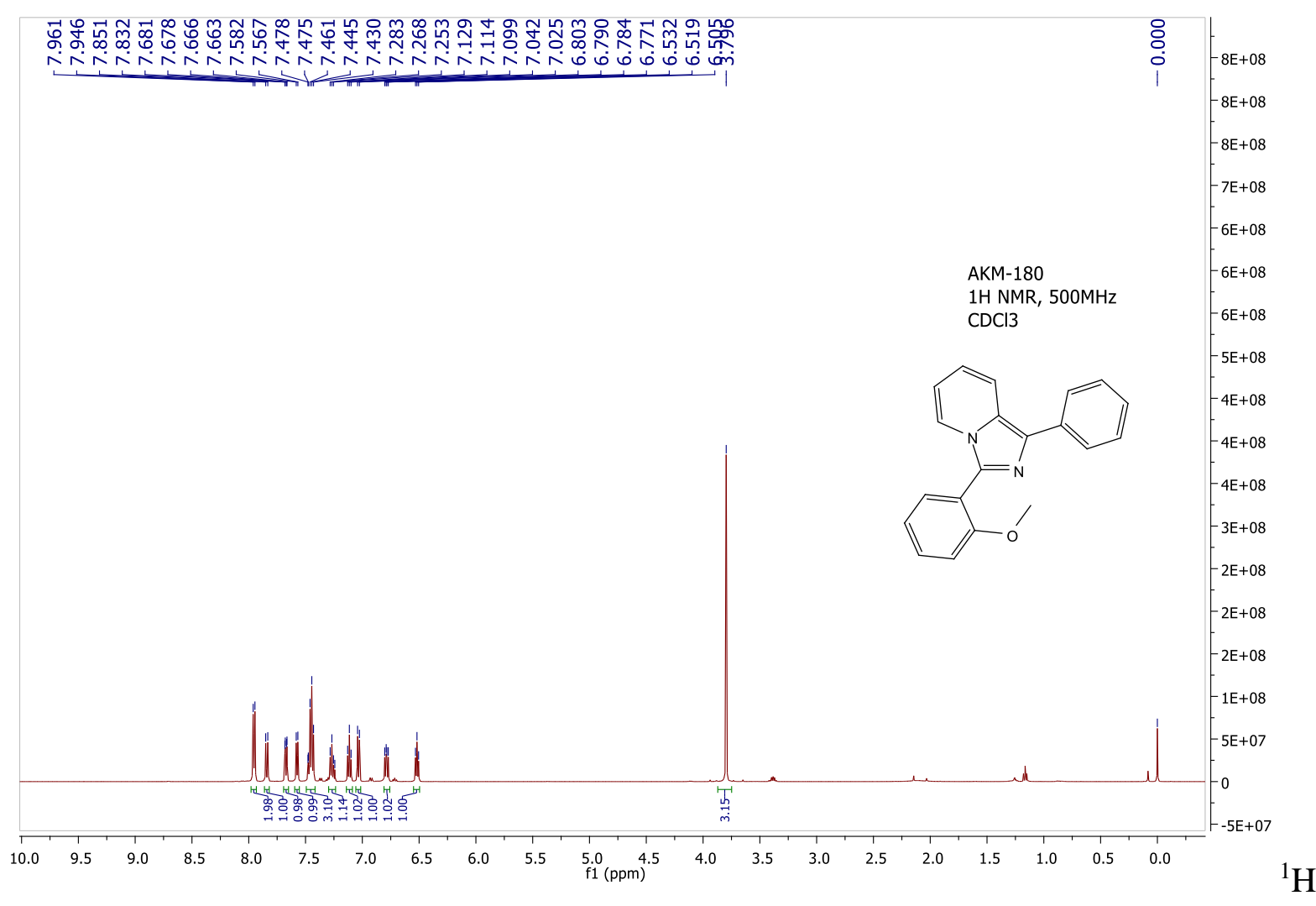

NMR of $\mathbf{3 r}$

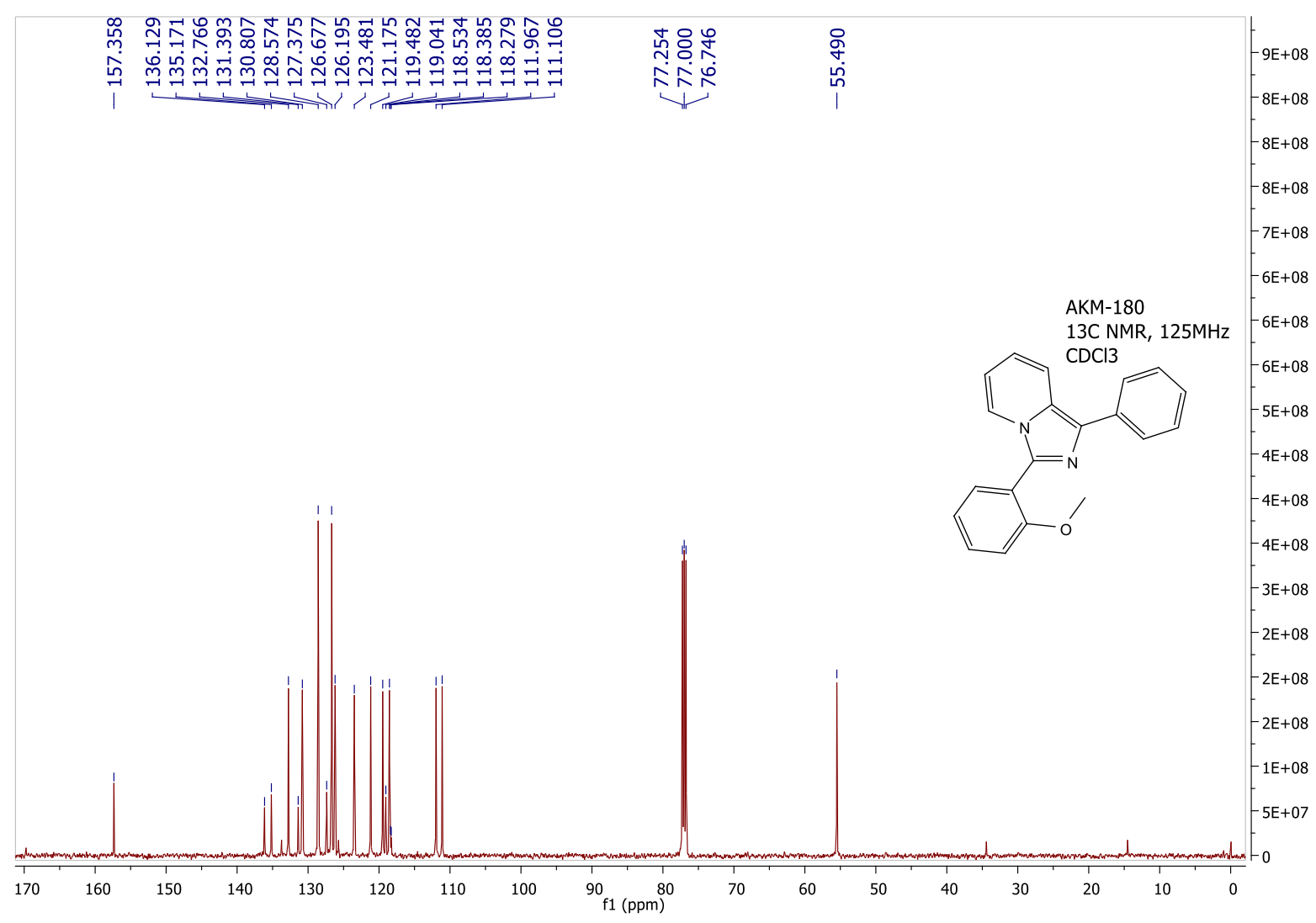

${ }^{13} \mathrm{C}$ NMR of $3 r$ 


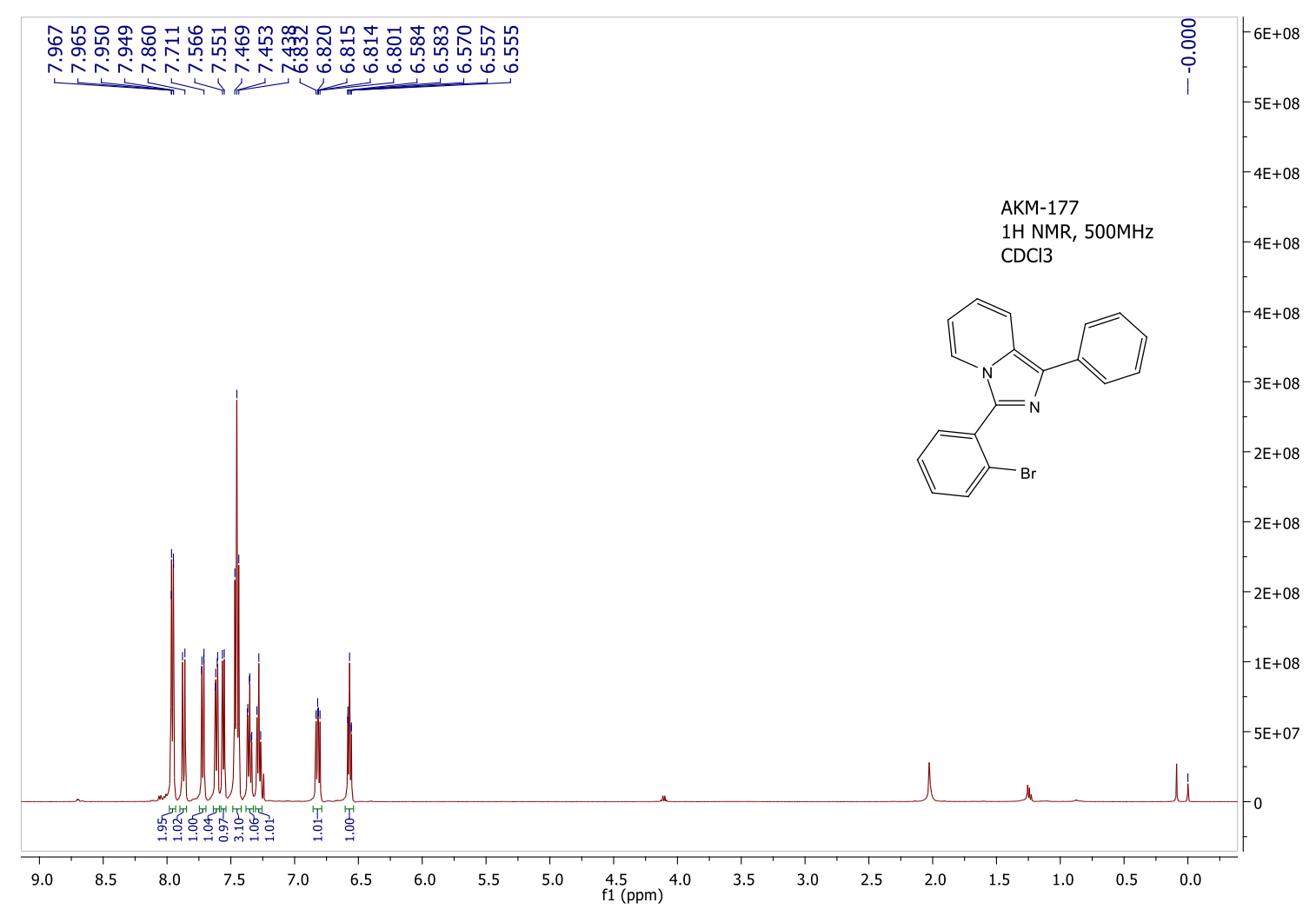

NMR of 3s

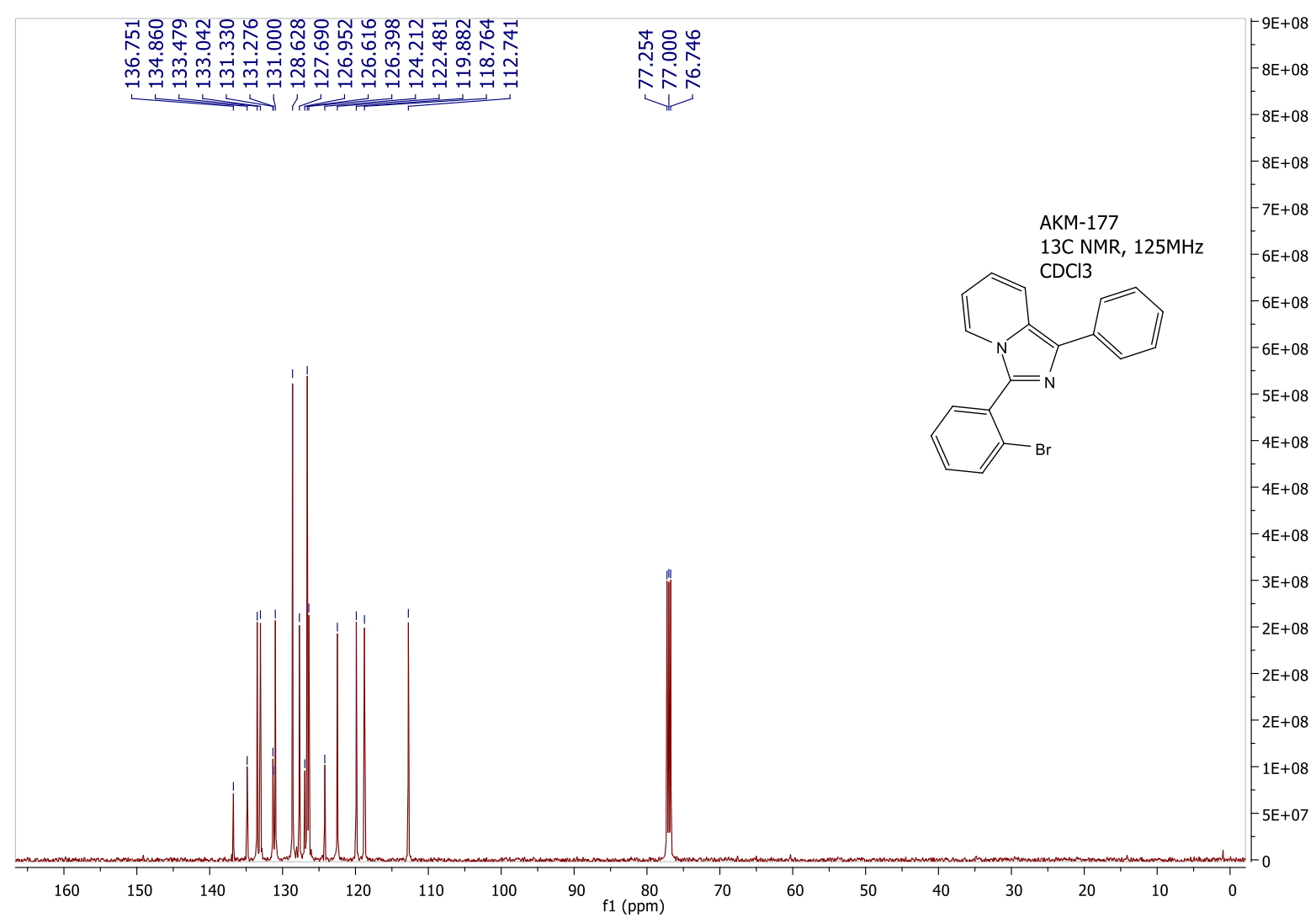

${ }^{13} \mathrm{C}$ NMR of $3 \mathrm{~s}$ 


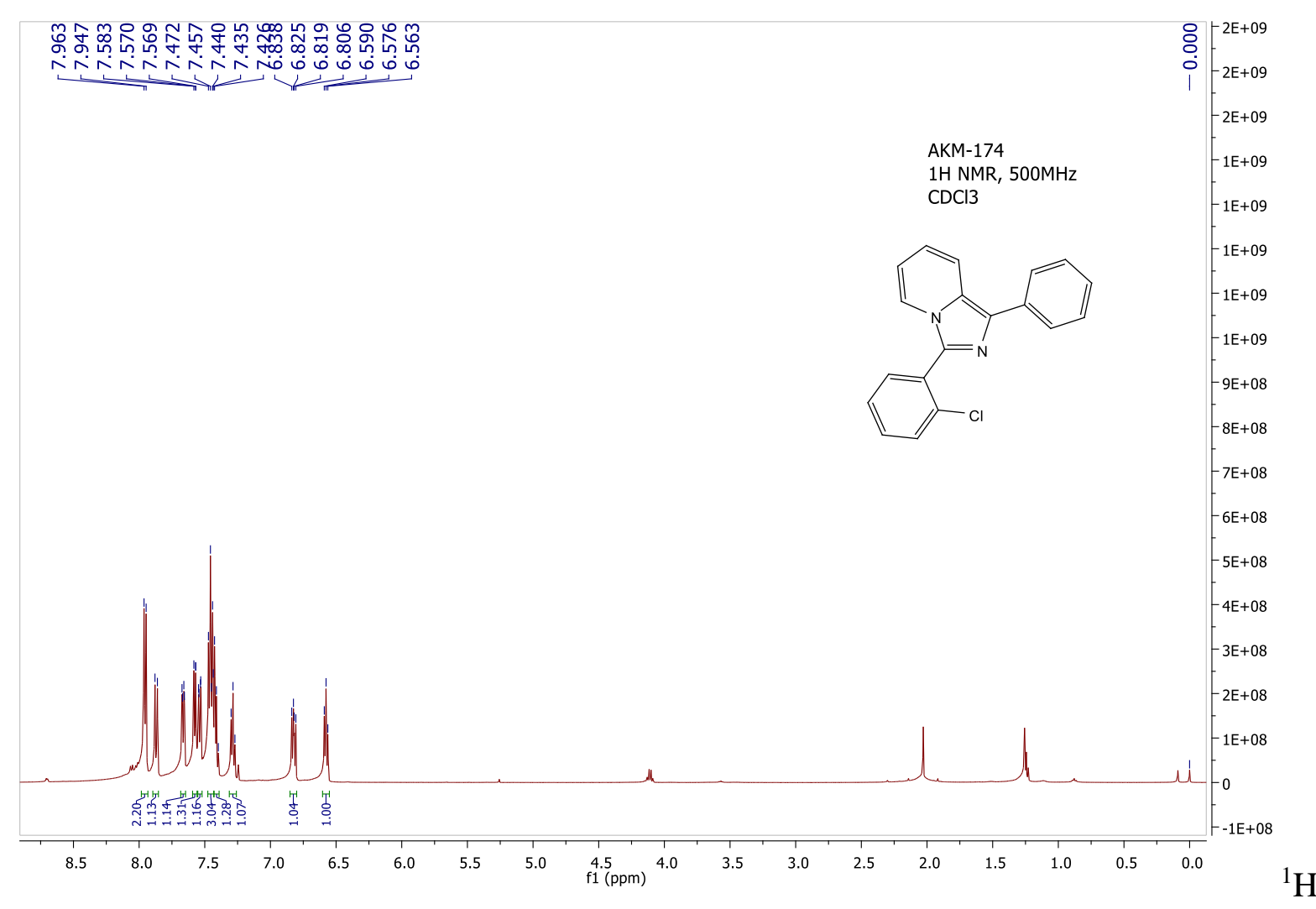

NMR of $\mathbf{3 t}$

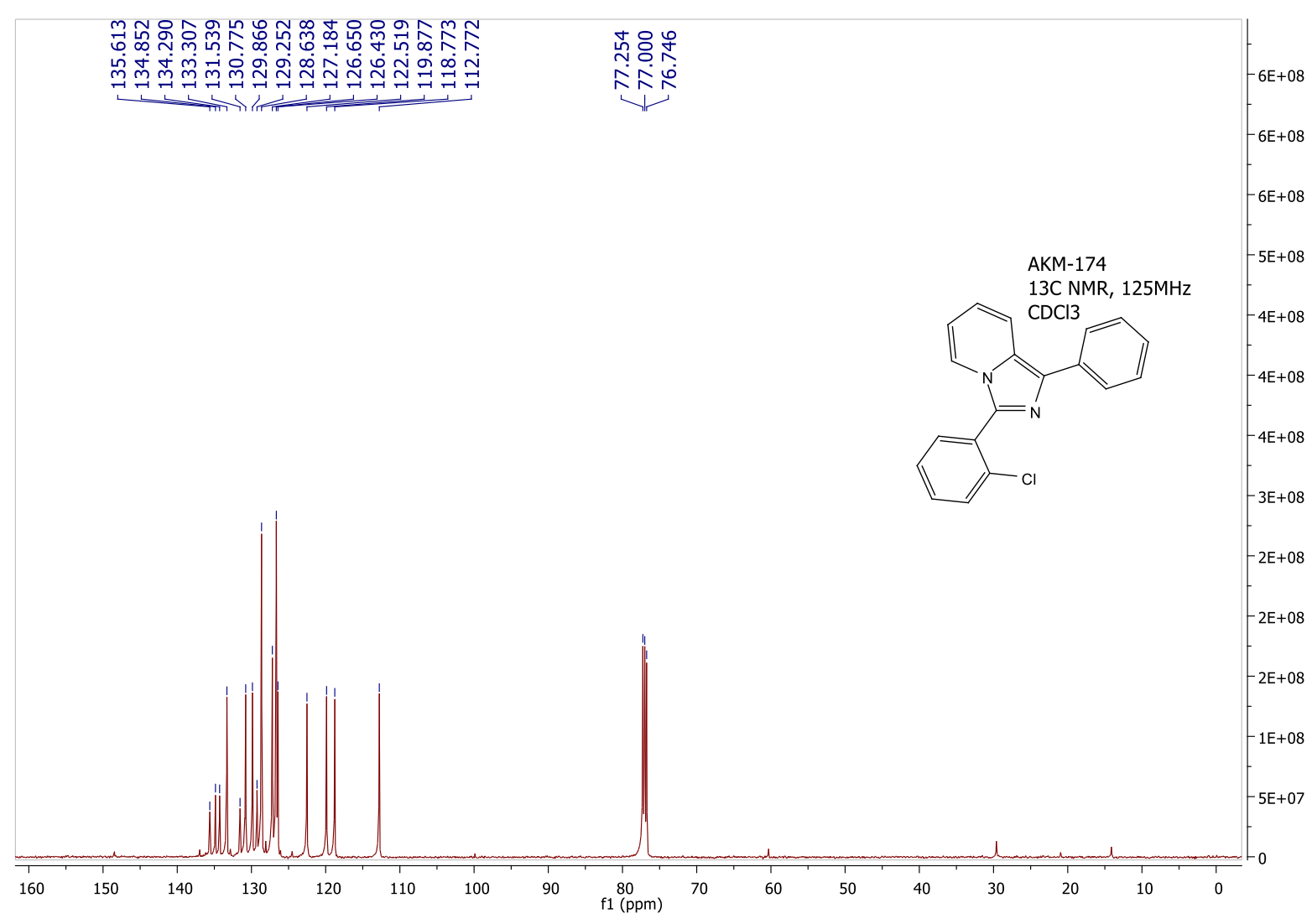

${ }^{13} \mathrm{C}$ NMR of $\mathbf{3 t}$ 


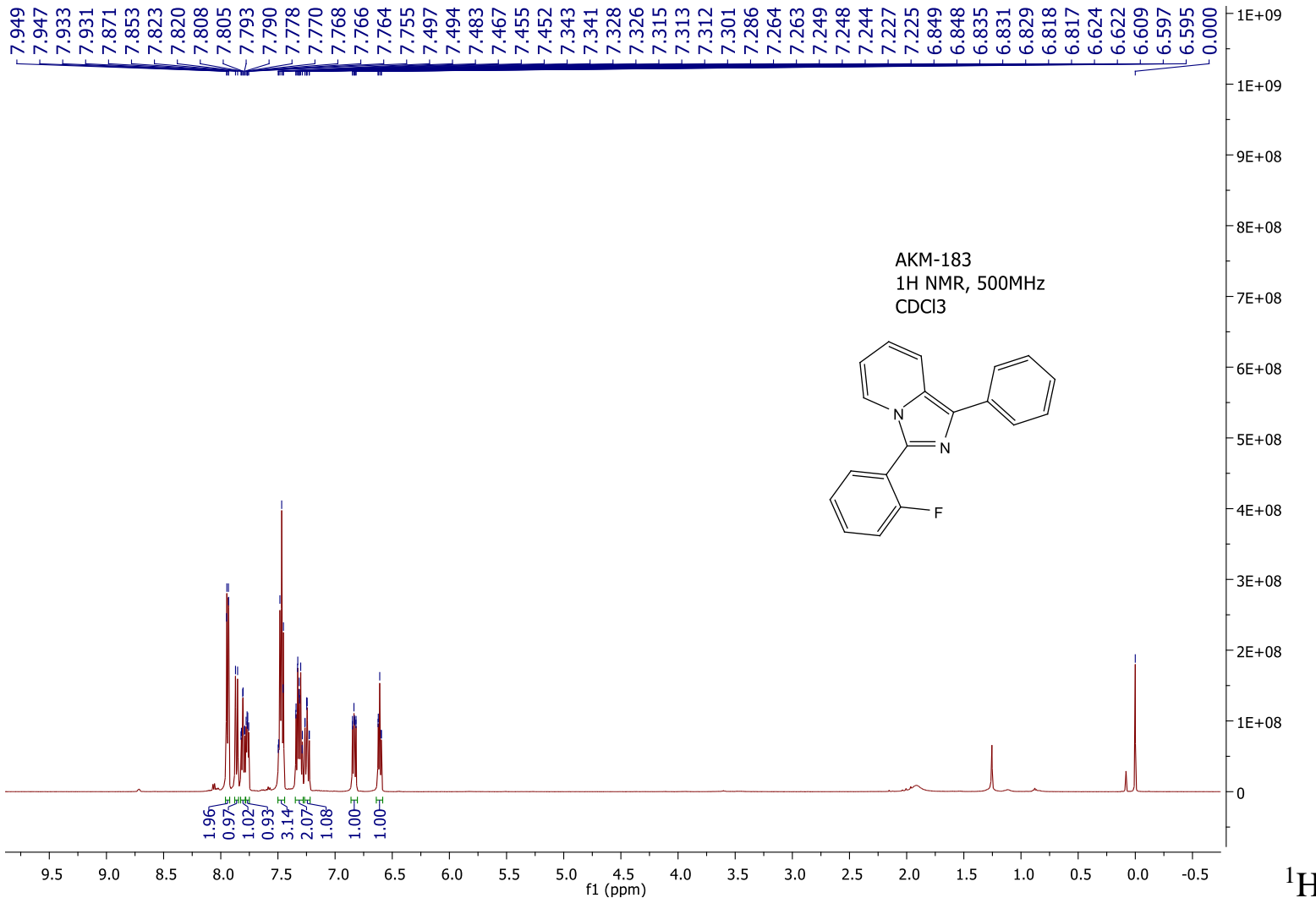

\section{NMR of 3u}

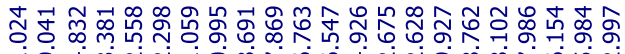

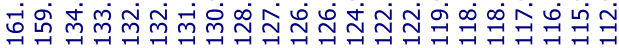

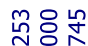

NÑ

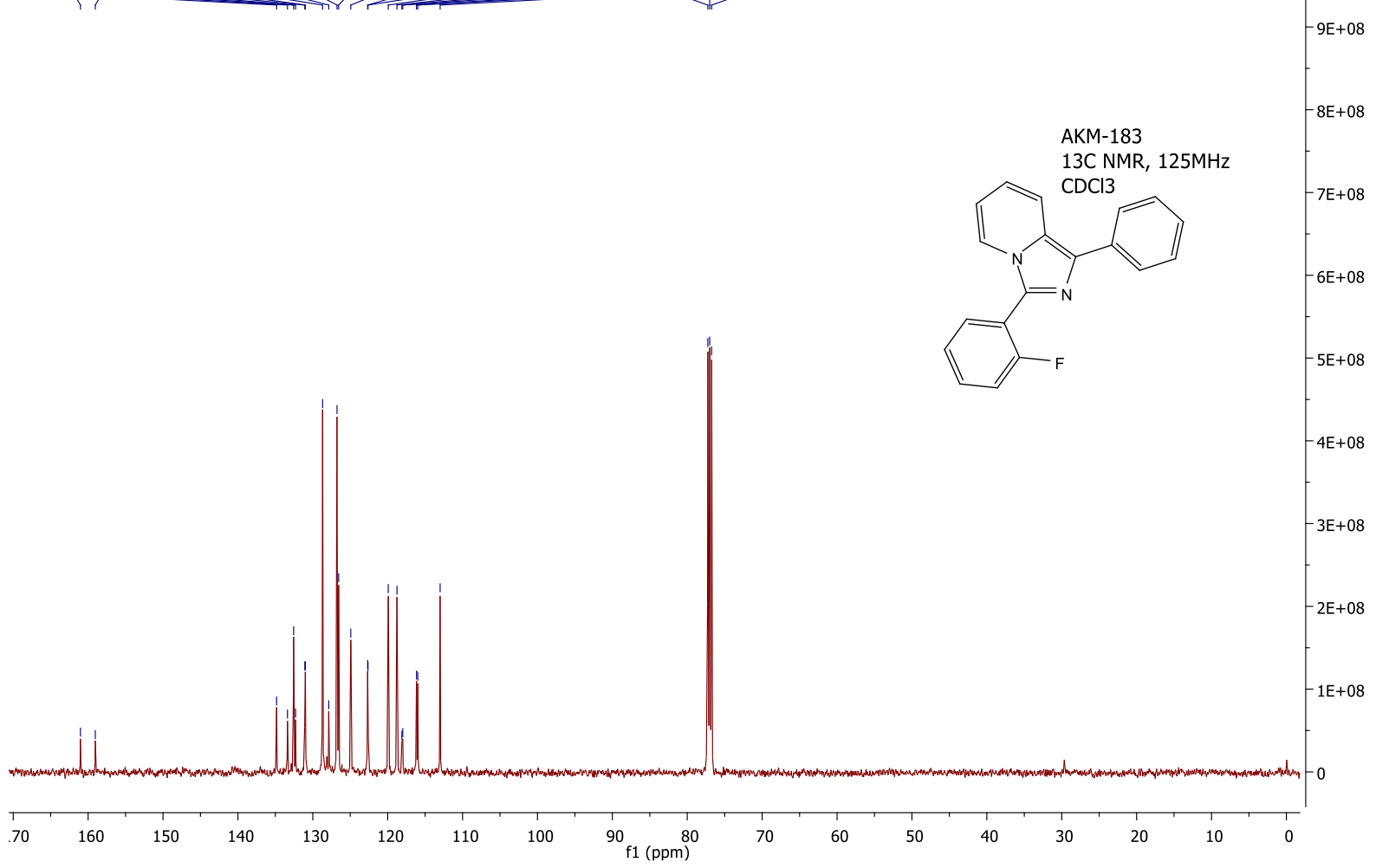

${ }^{13} \mathrm{C}$ NMR of $\mathbf{3 u}$ 


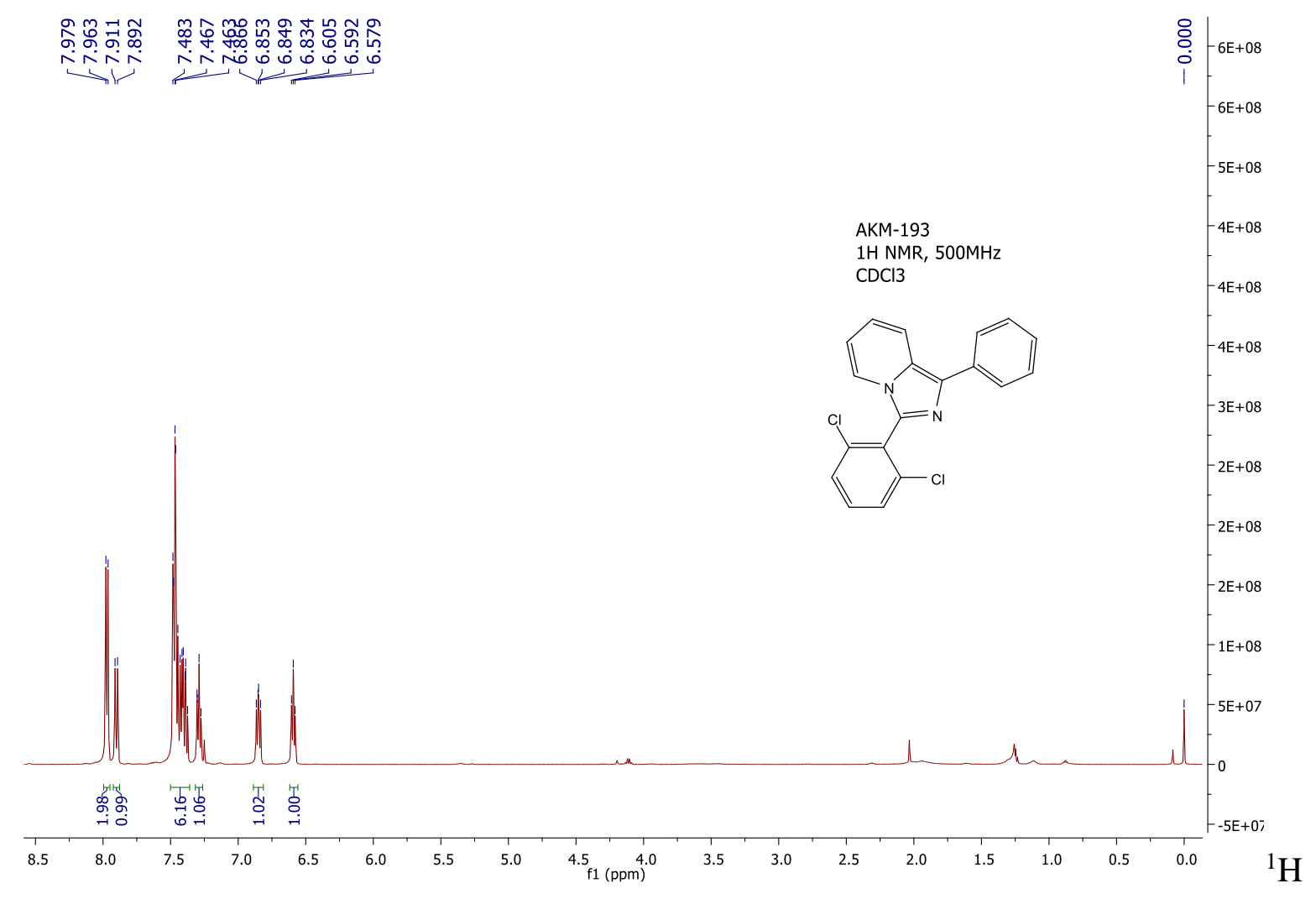

NMR of $\mathbf{3 v}$

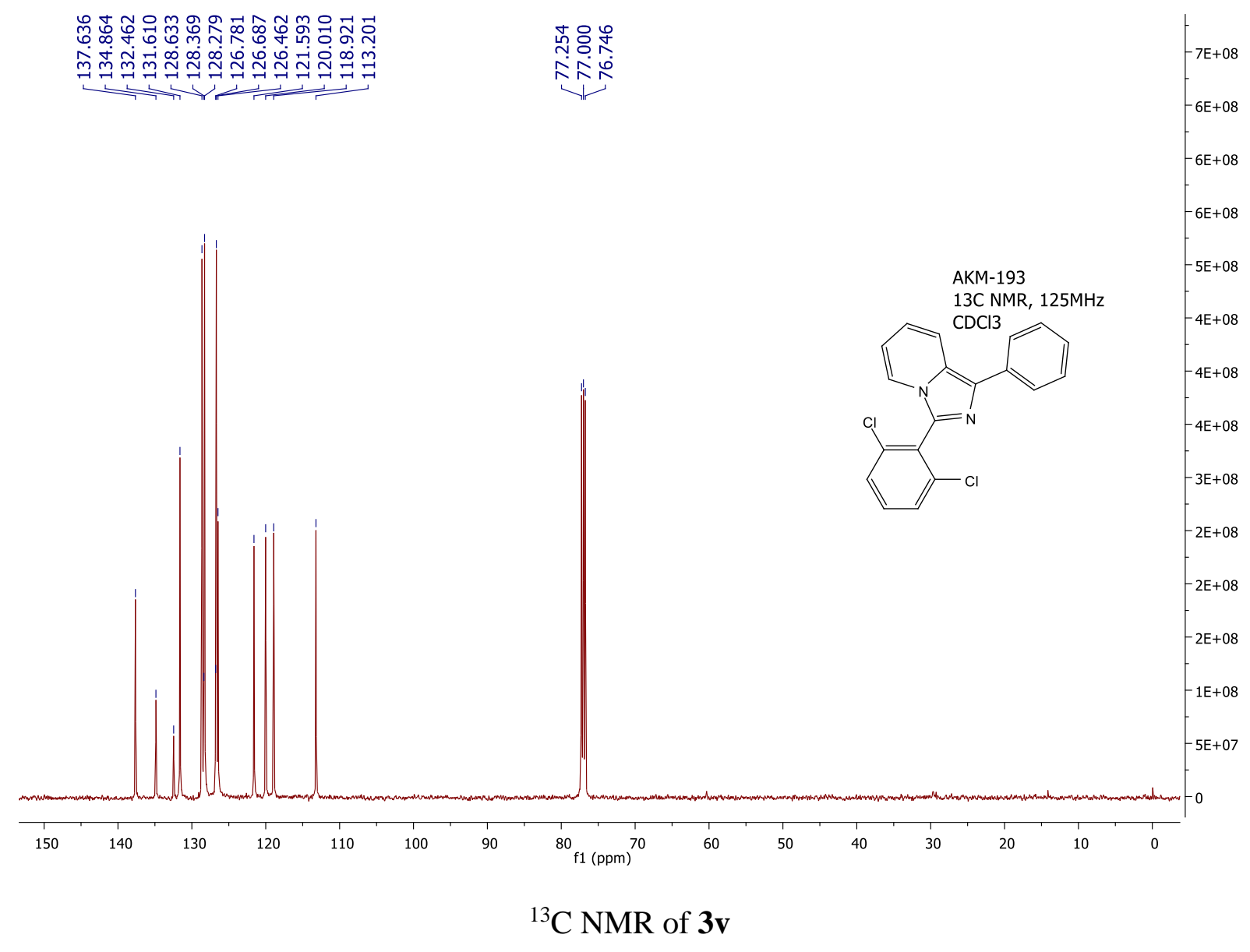




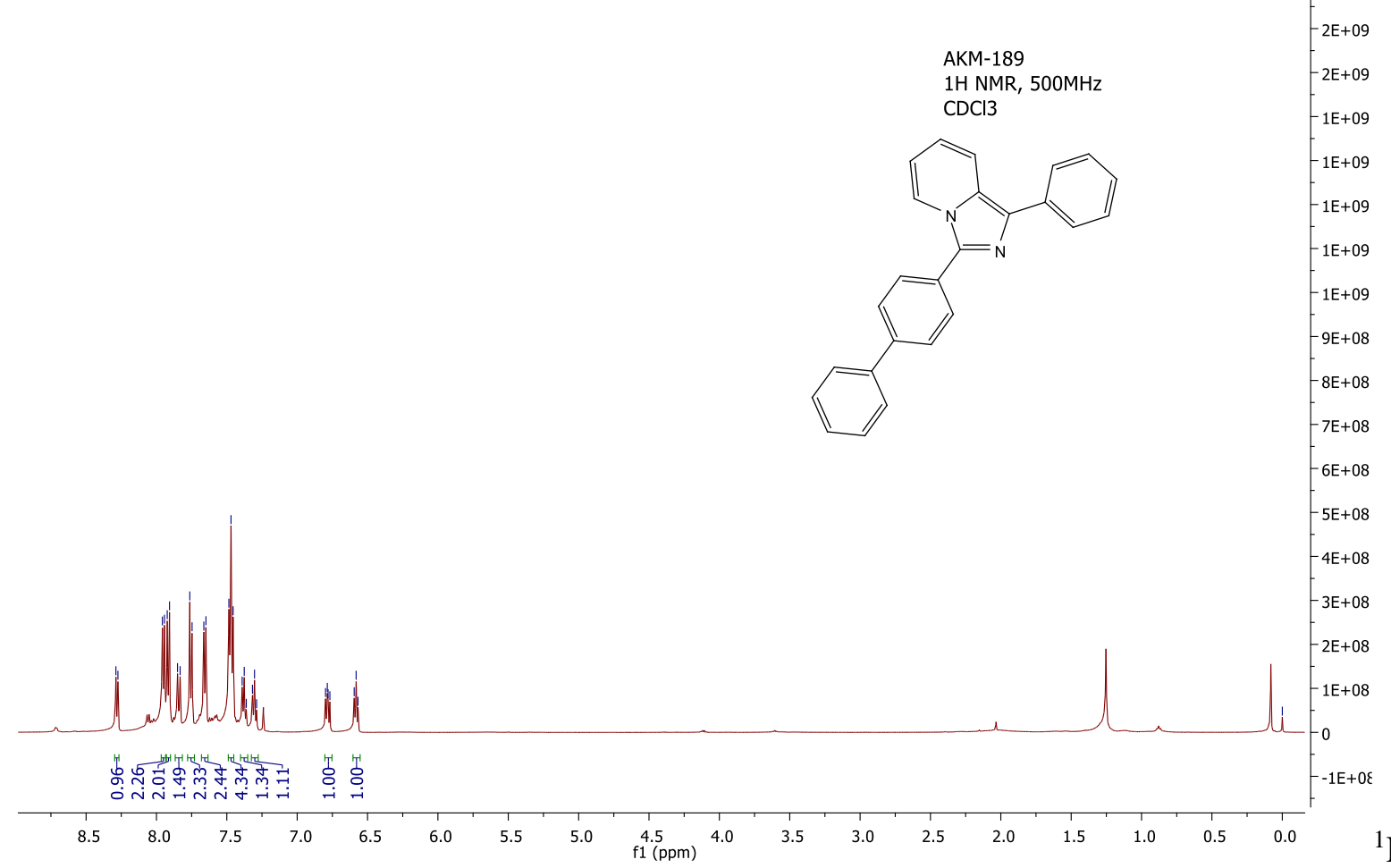

\section{NMR of 3w}

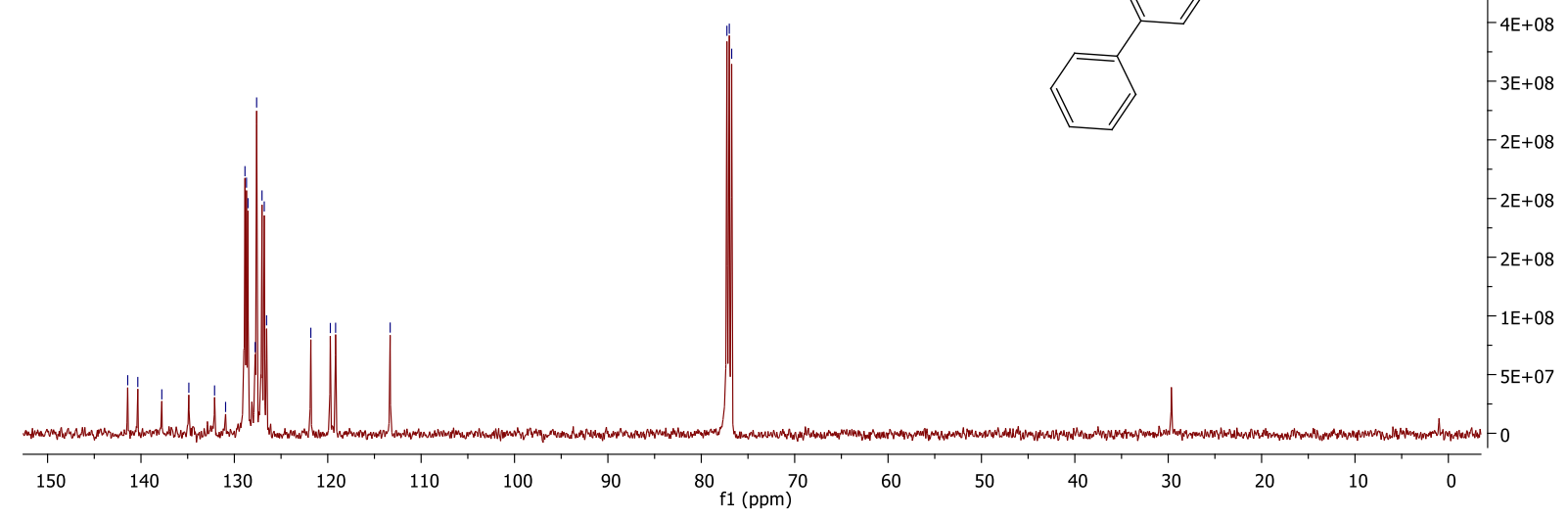

\section{${ }^{13} \mathrm{C}$ NMR of $\mathbf{3 w}$}




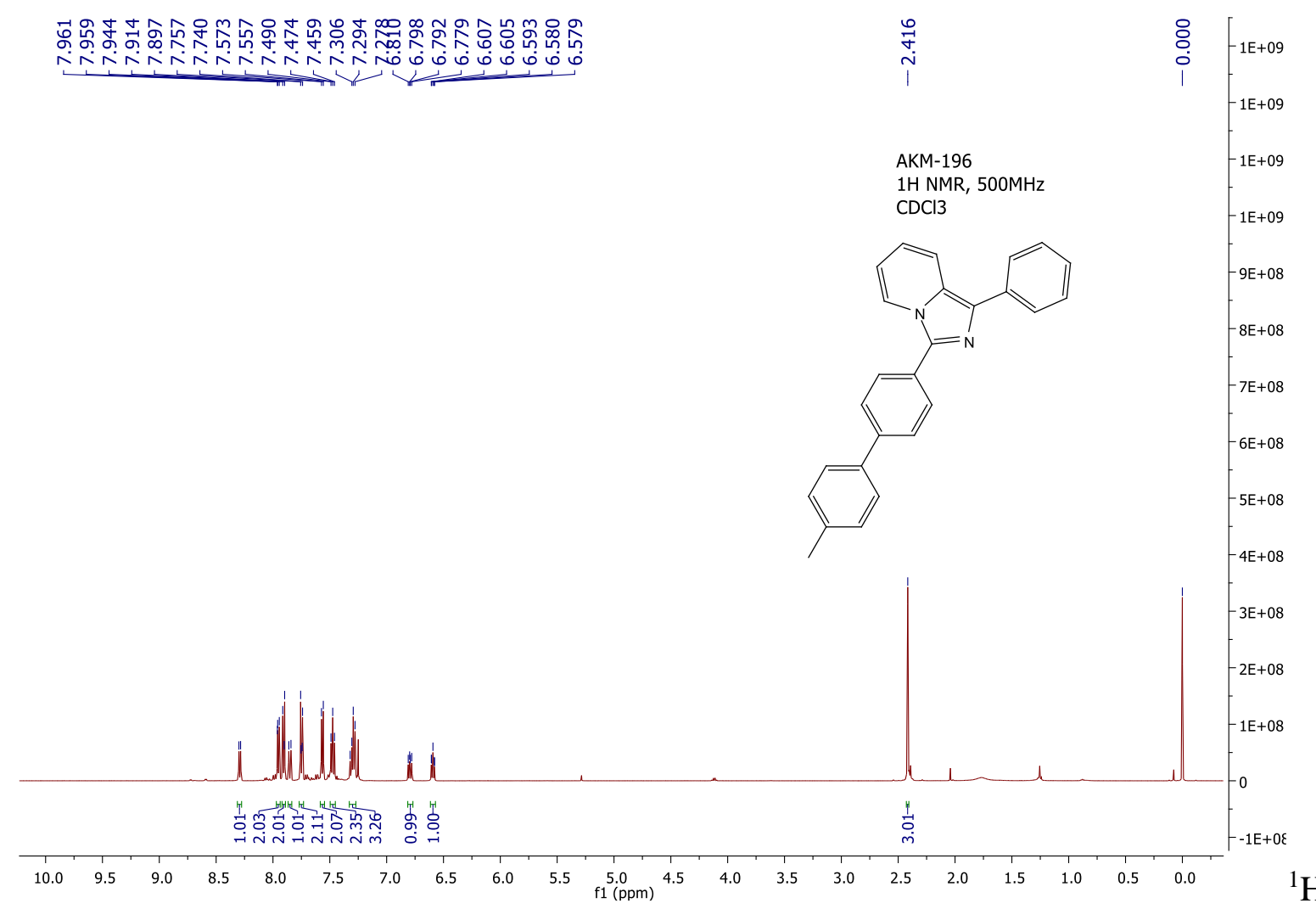

\section{NMR of $\mathbf{3 x}$}

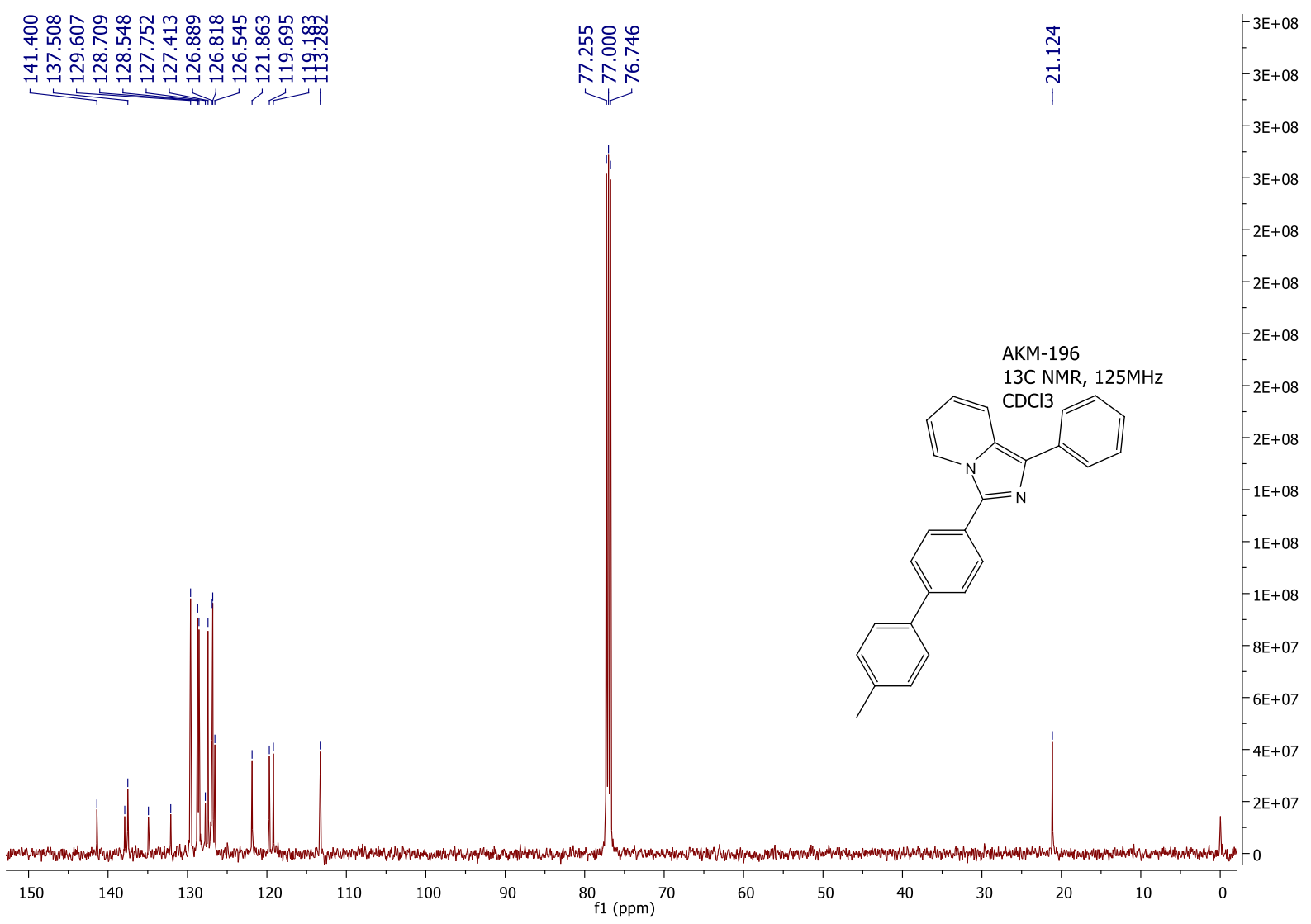

${ }^{13} \mathrm{C}$ NMR of $\mathbf{3 x}$ 


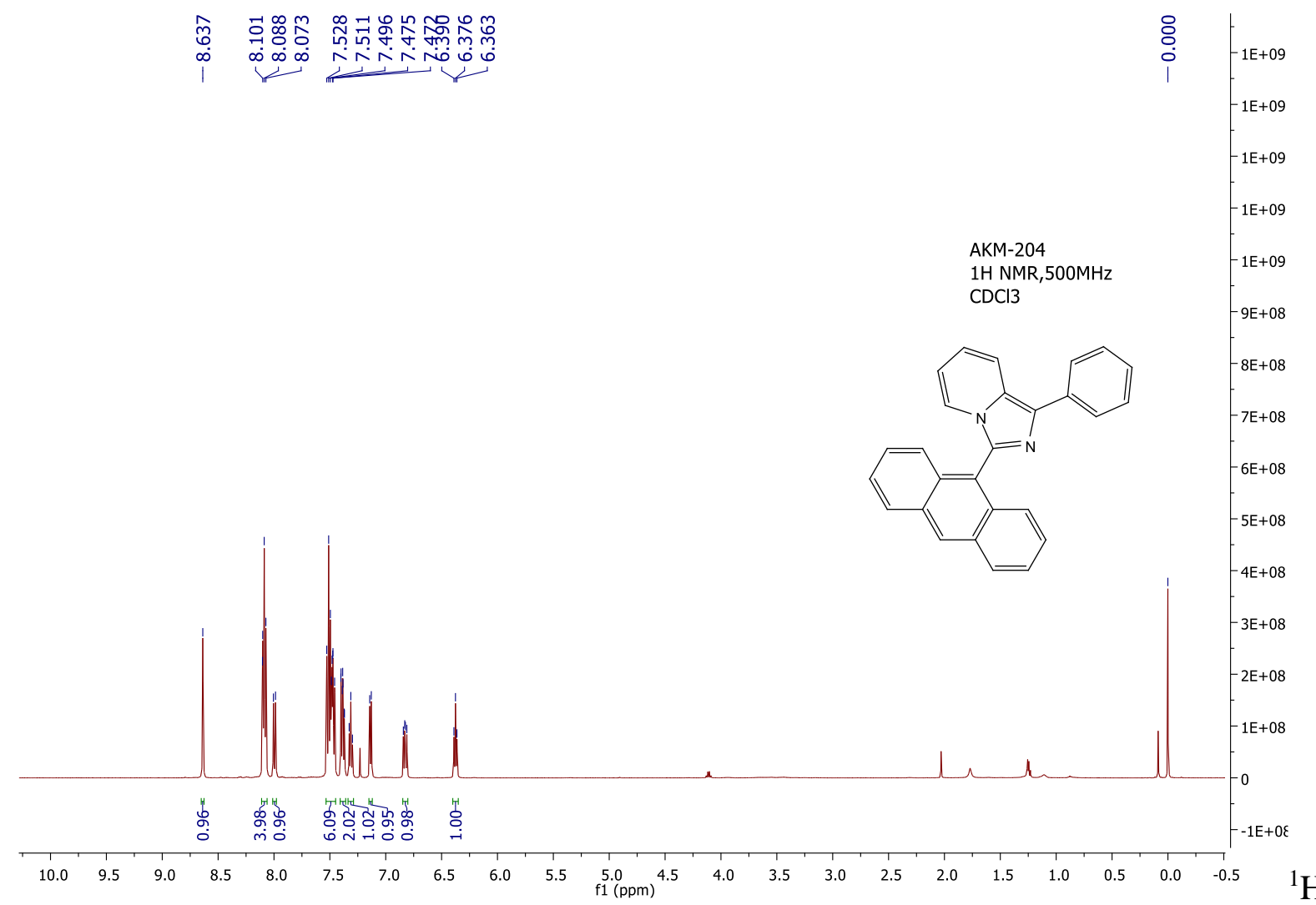

NMR of $\mathbf{3 y}$

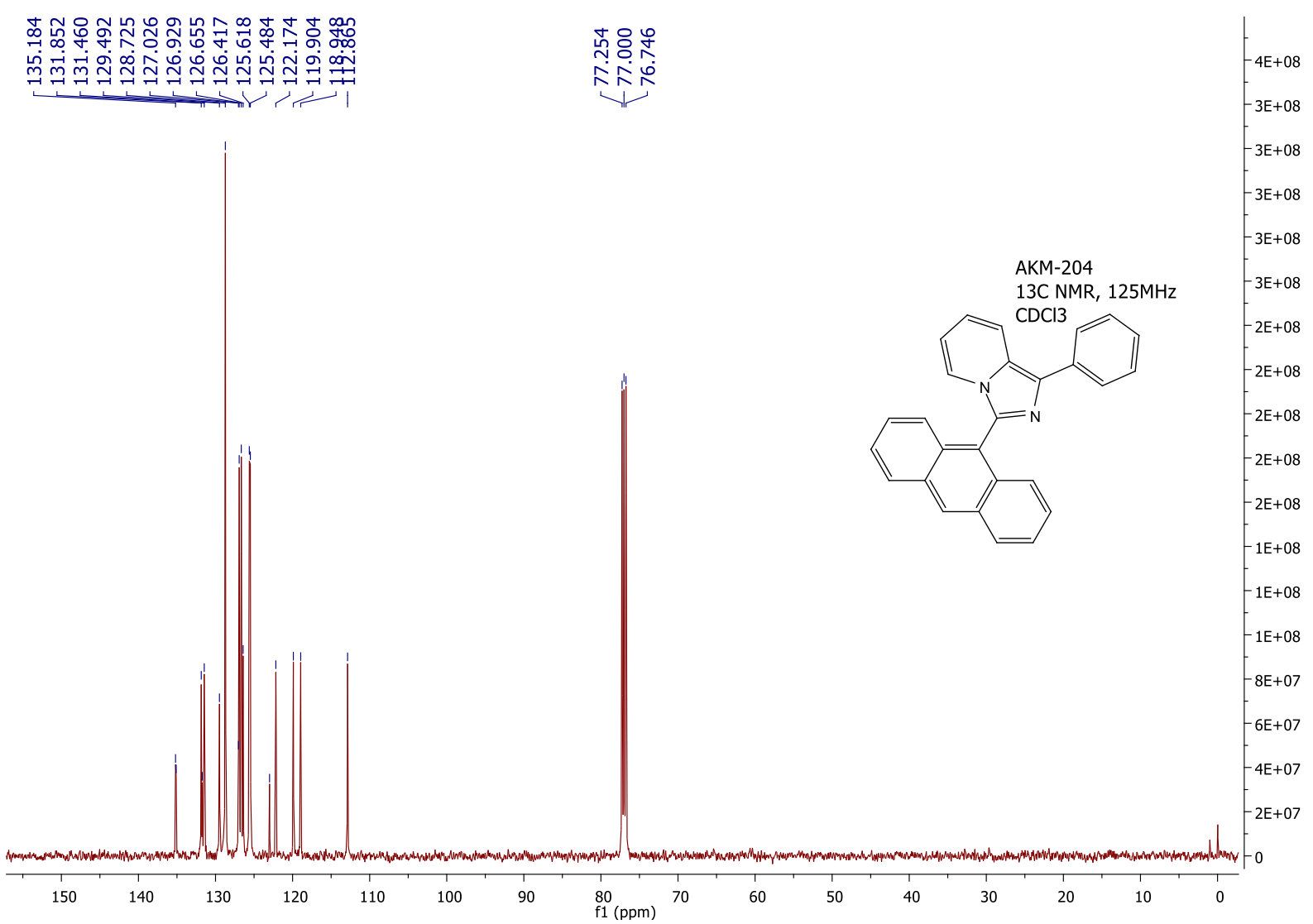

${ }^{13} \mathrm{C}$ NMR of $\mathbf{3 y}$ 


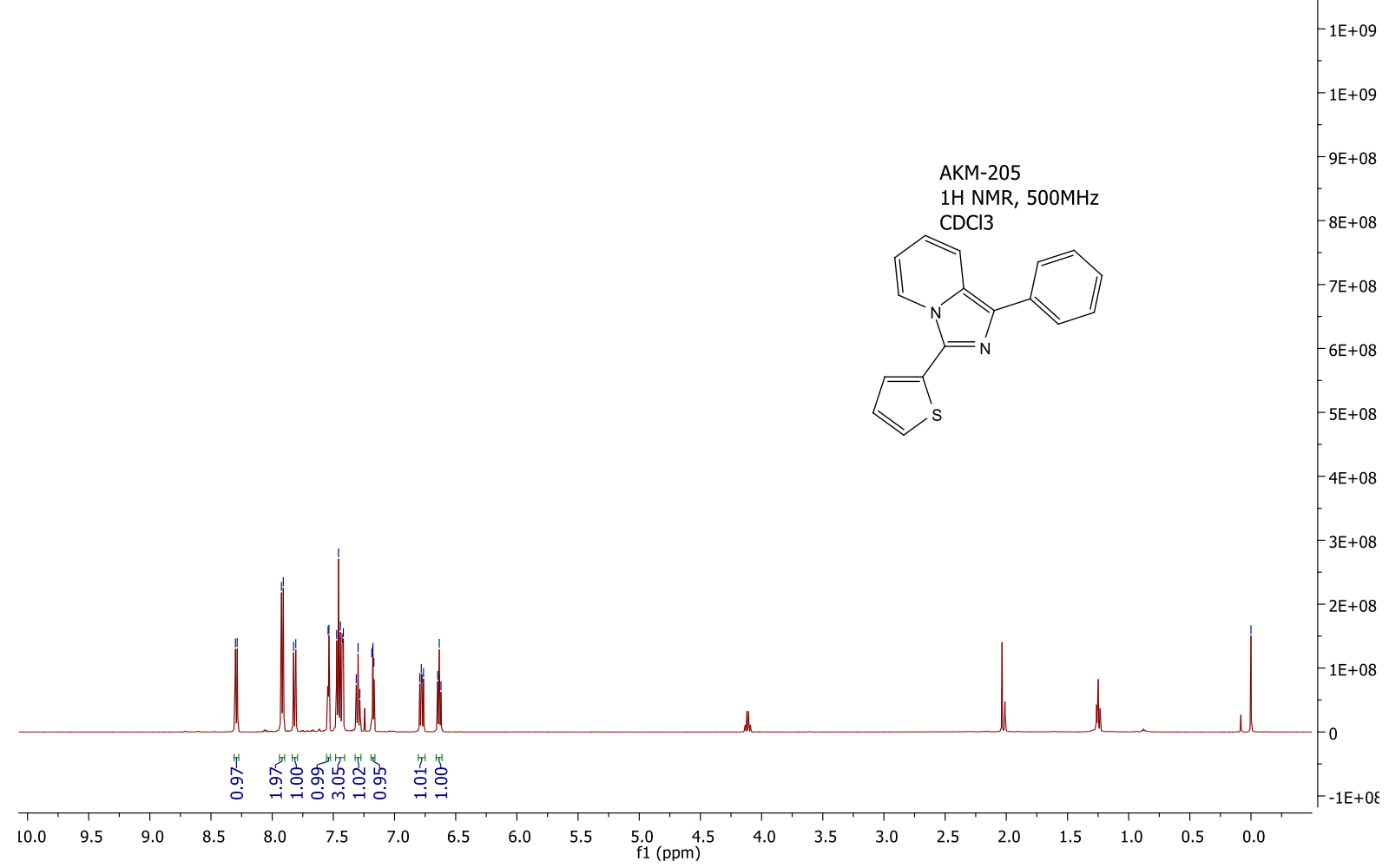

${ }^{1} \mathrm{H}$ NMR of $\mathbf{3 z}$

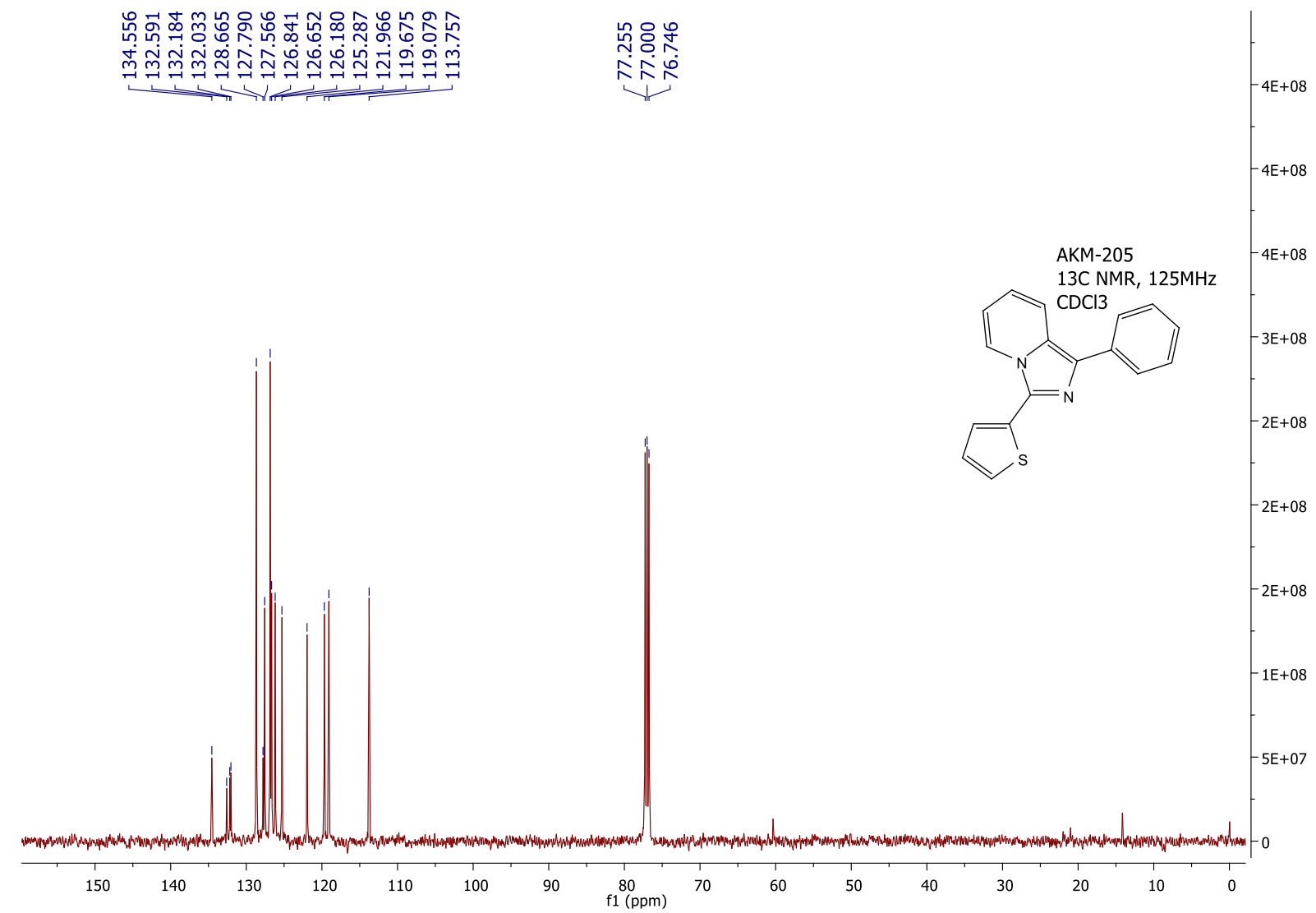


${ }^{13} \mathrm{C}$ NMR of $\mathbf{3 z}$

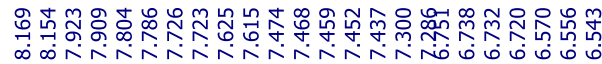

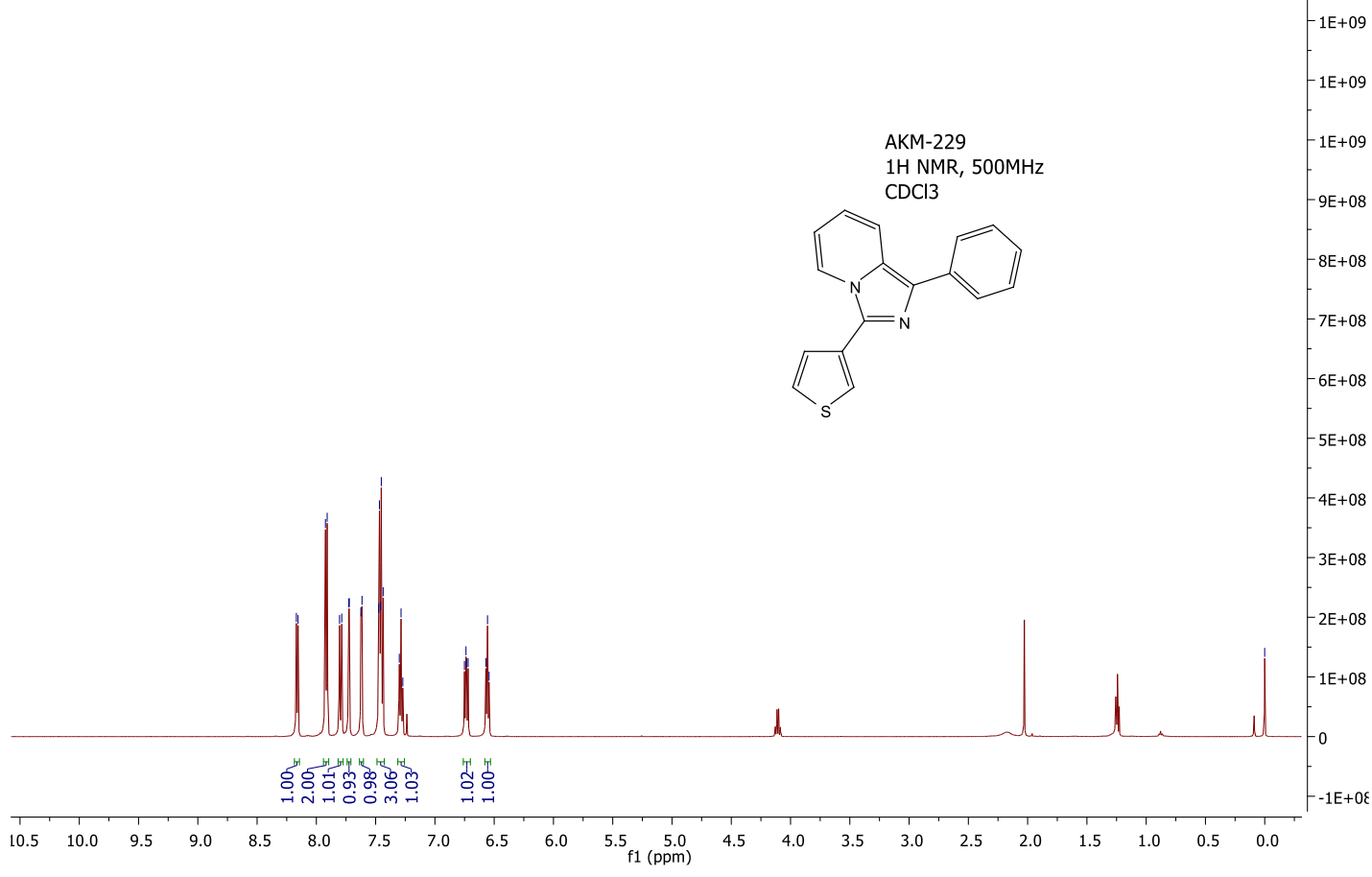

${ }^{1} \mathrm{H}$ NMR of 3aa

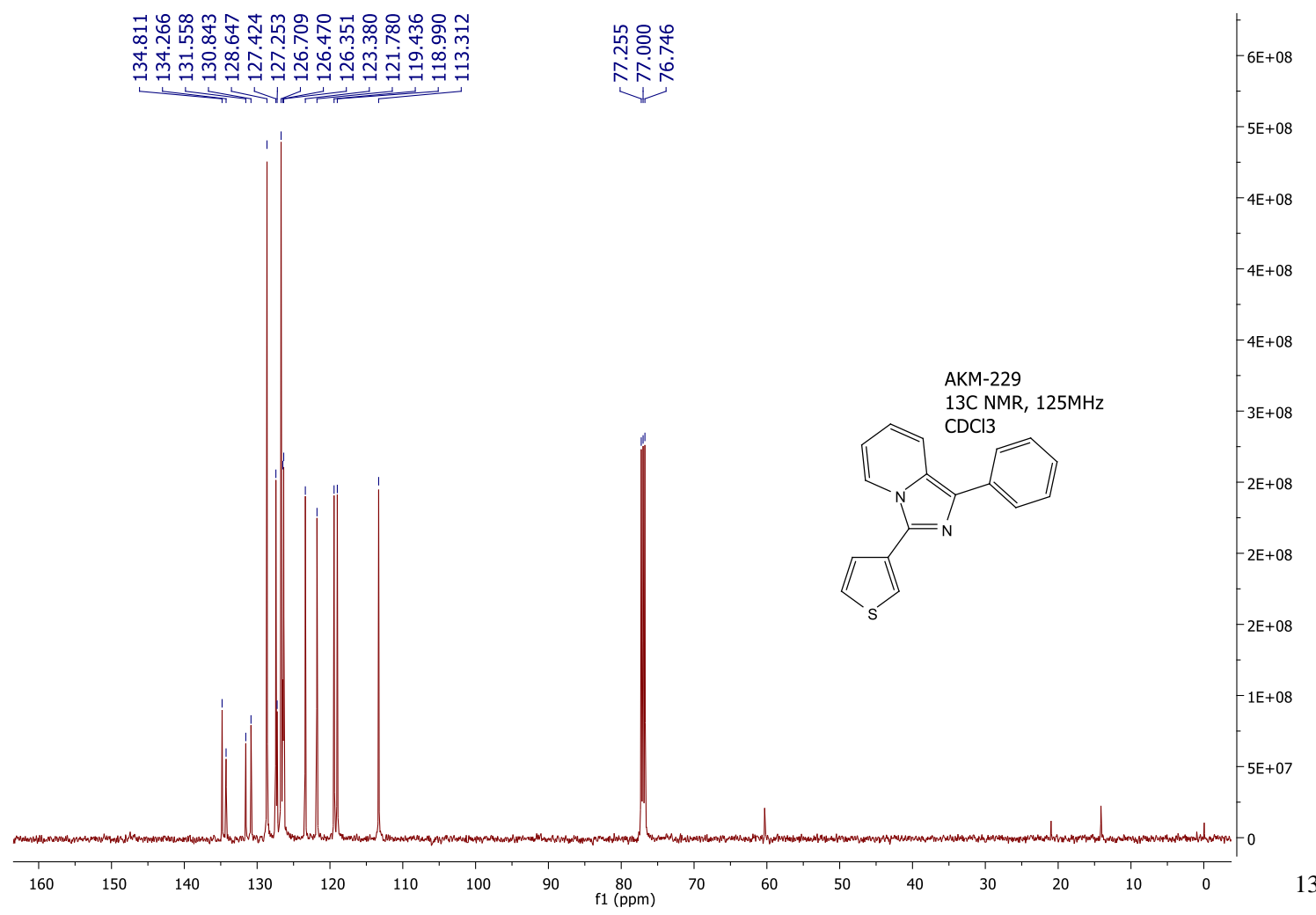

NMR of $\mathbf{3 a a}$ 


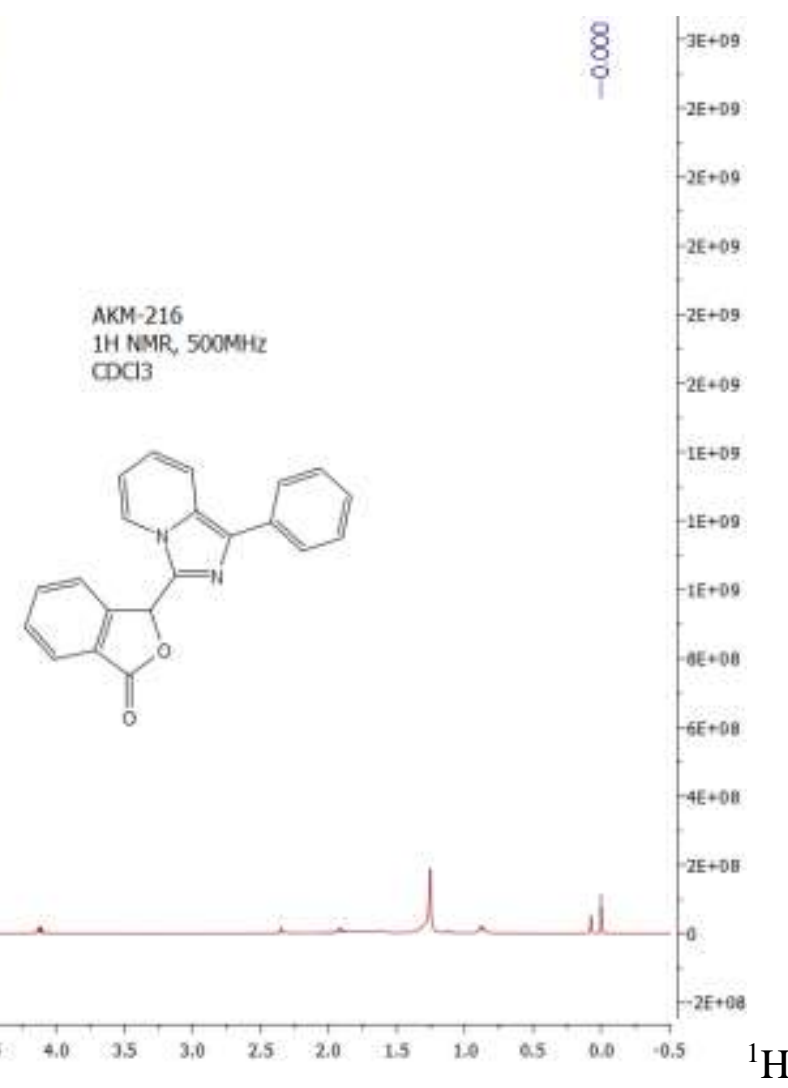

\section{NMR of 3ab}

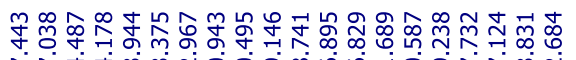

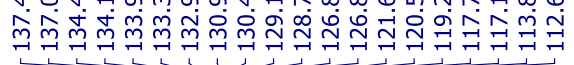

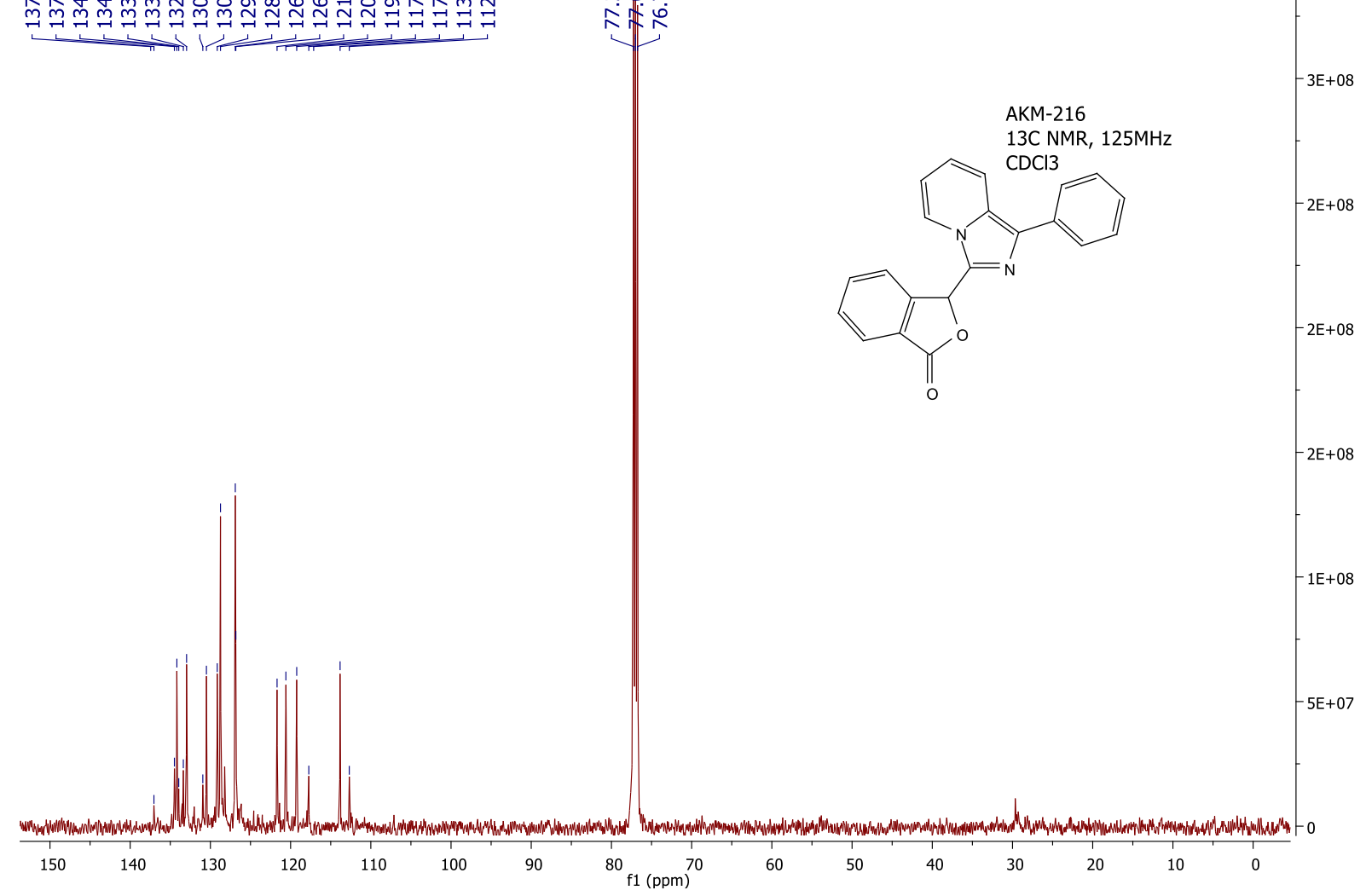

${ }^{13} \mathrm{C}$ NMR of $\mathbf{3 a b}$ 


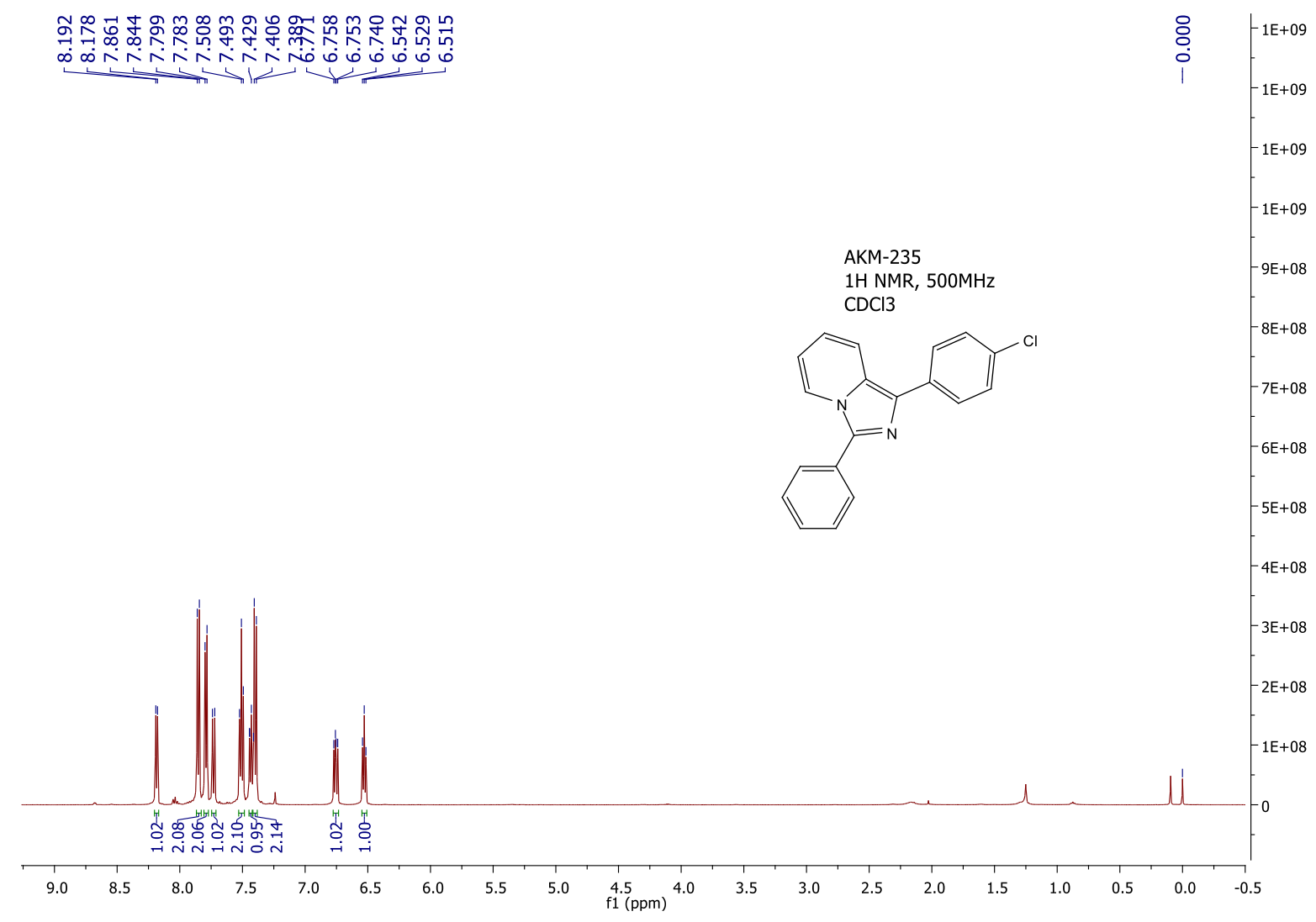

${ }^{1} \mathrm{H}$ NMR of $3 a c$

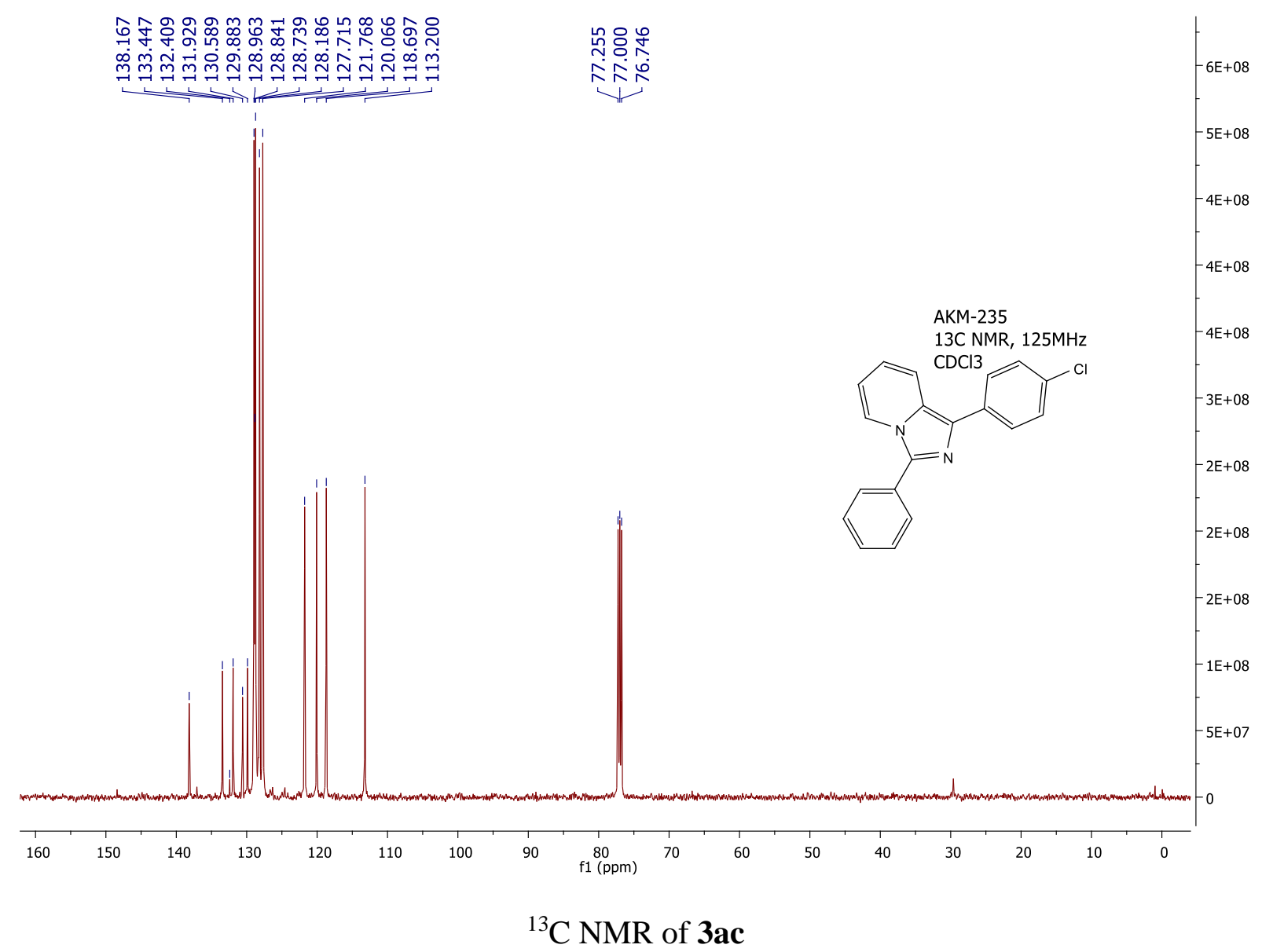



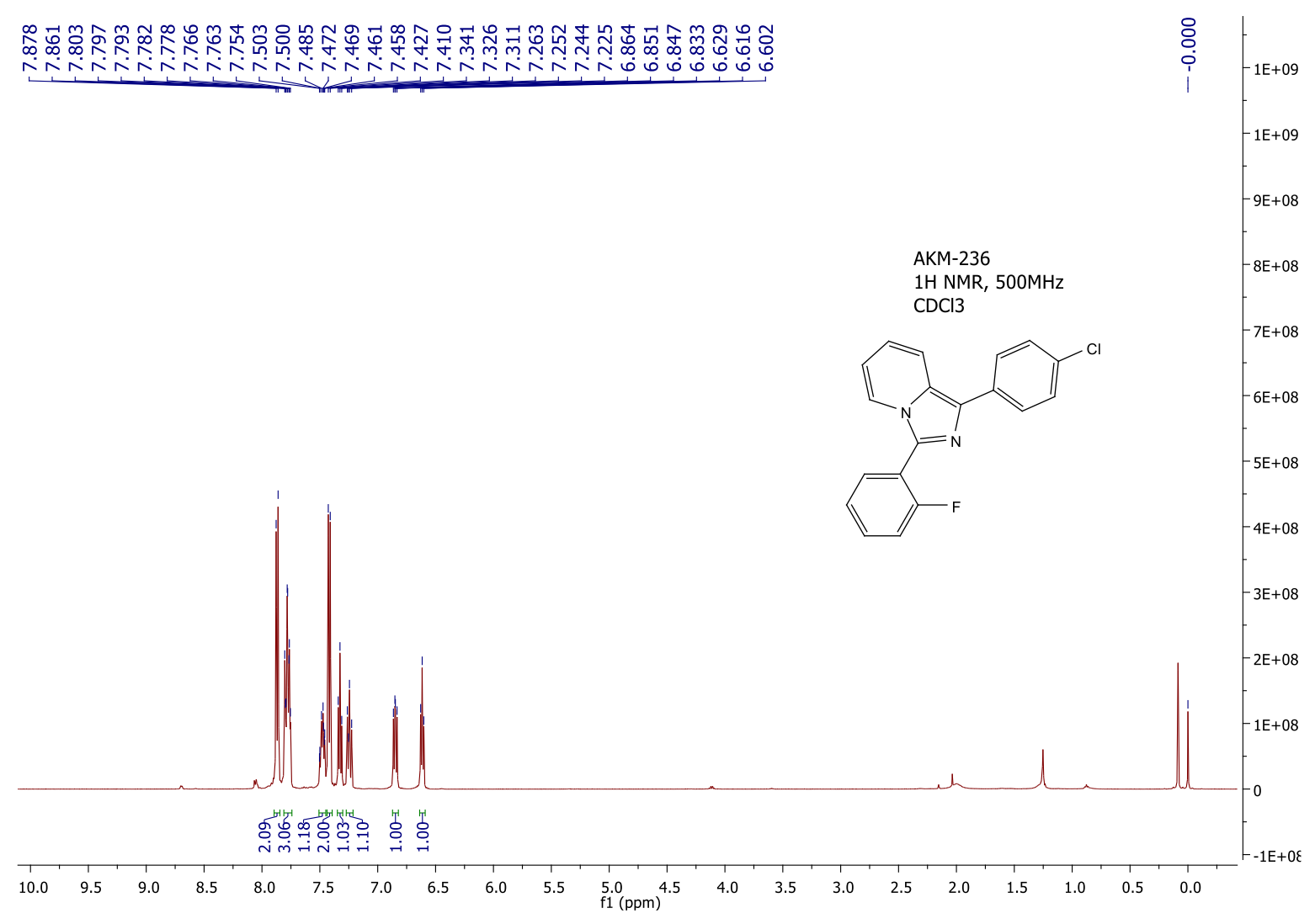

${ }^{1} \mathrm{H}$ NMR of $\mathbf{3 a d}$

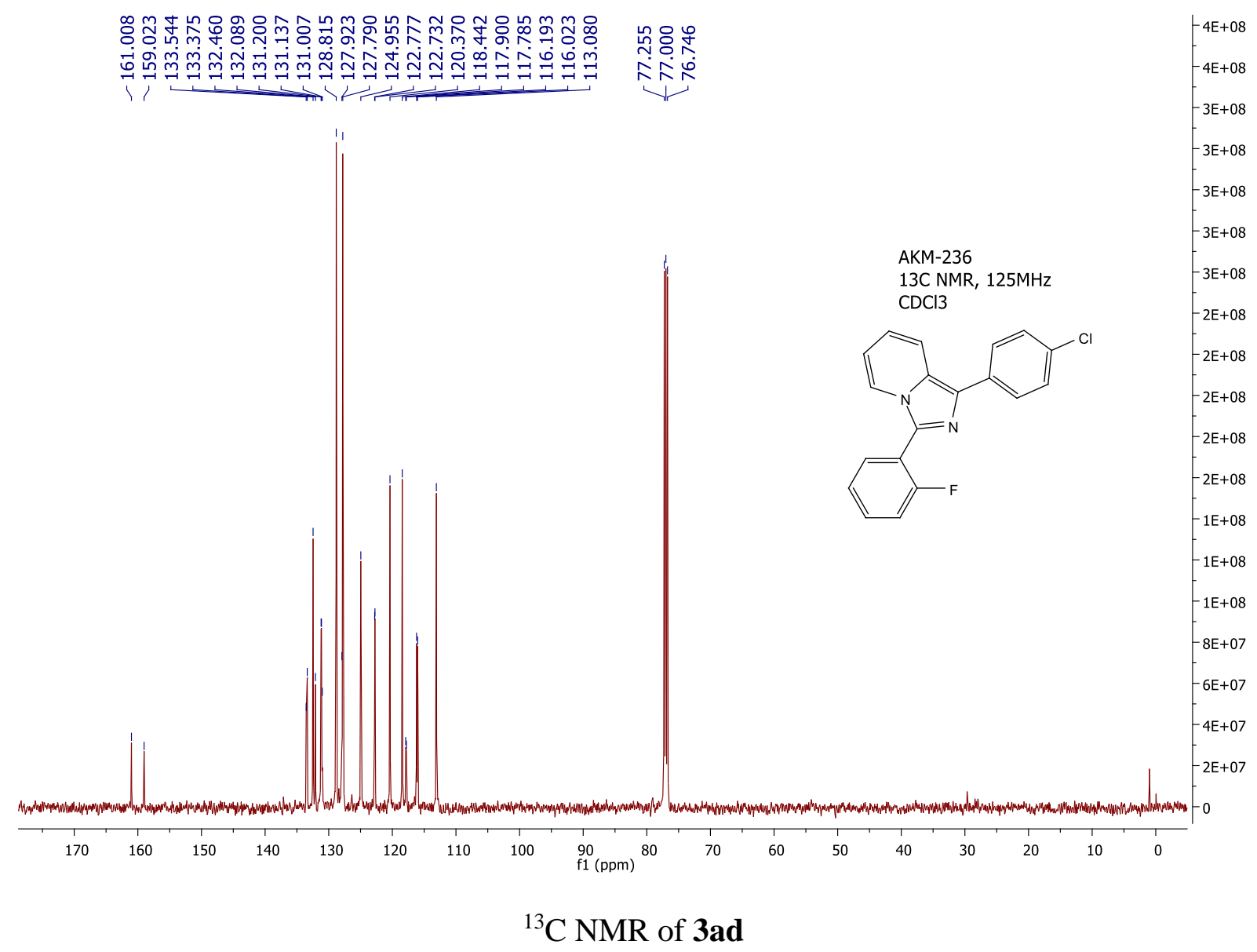




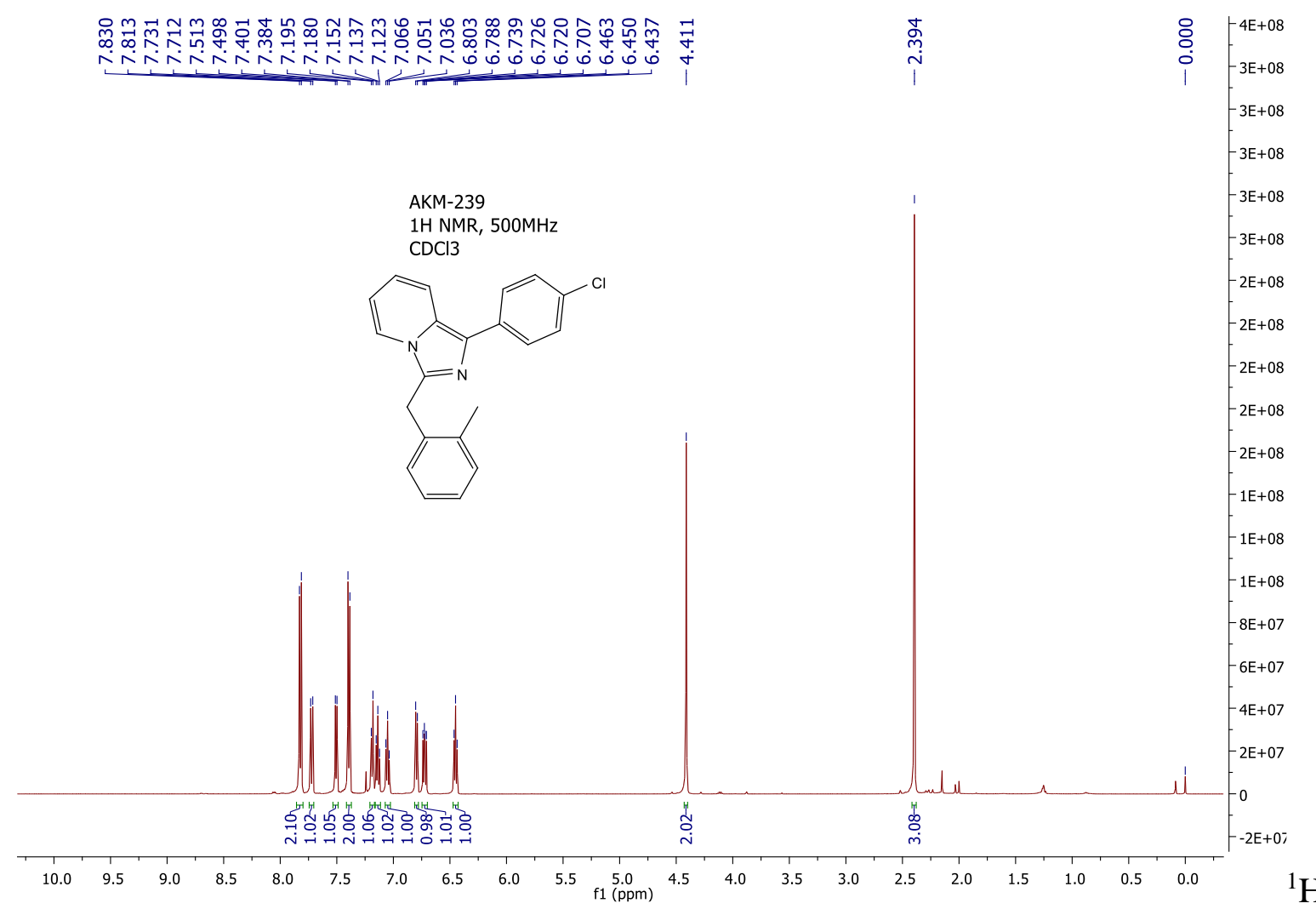

NMR of 3ae

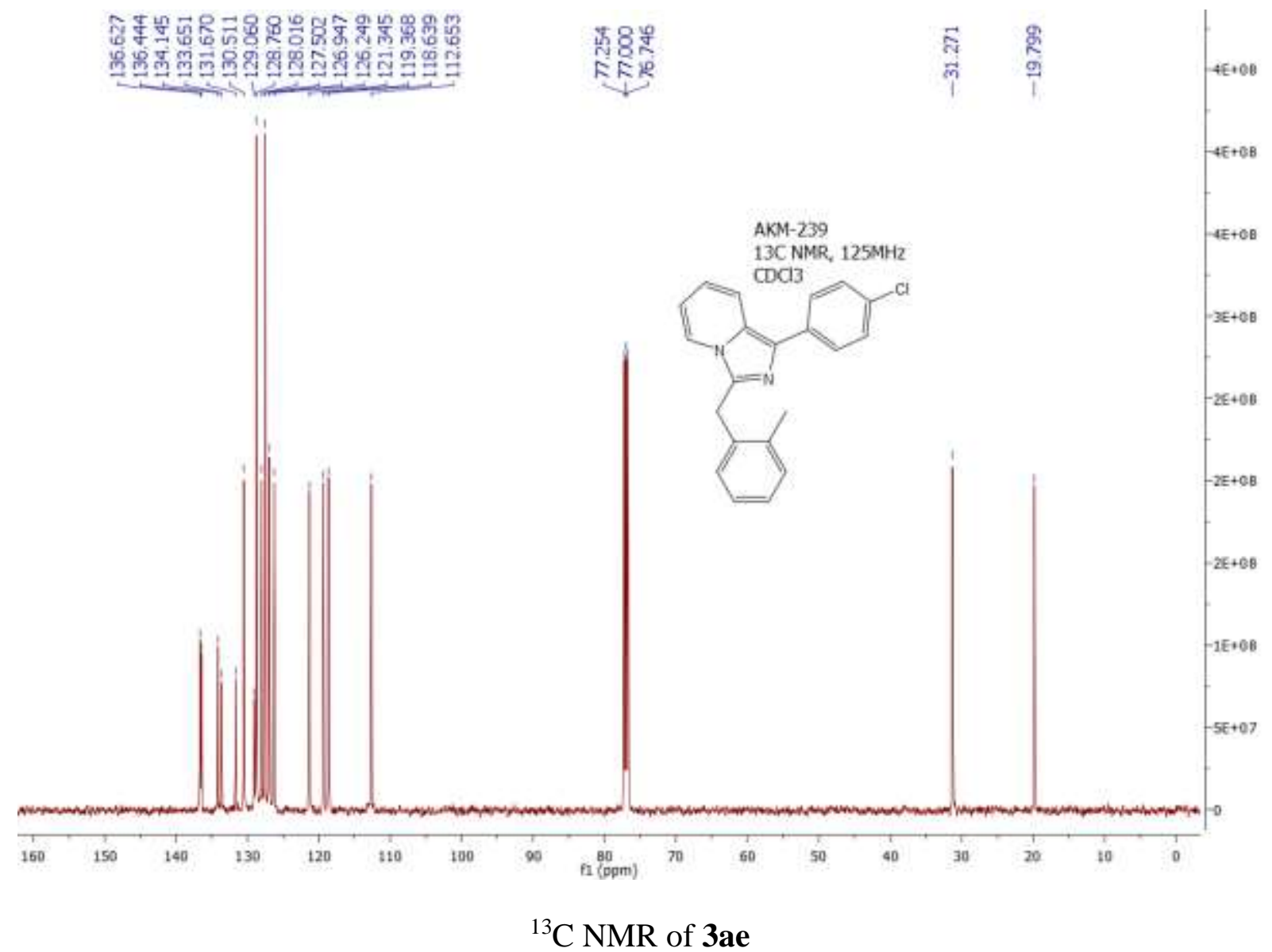



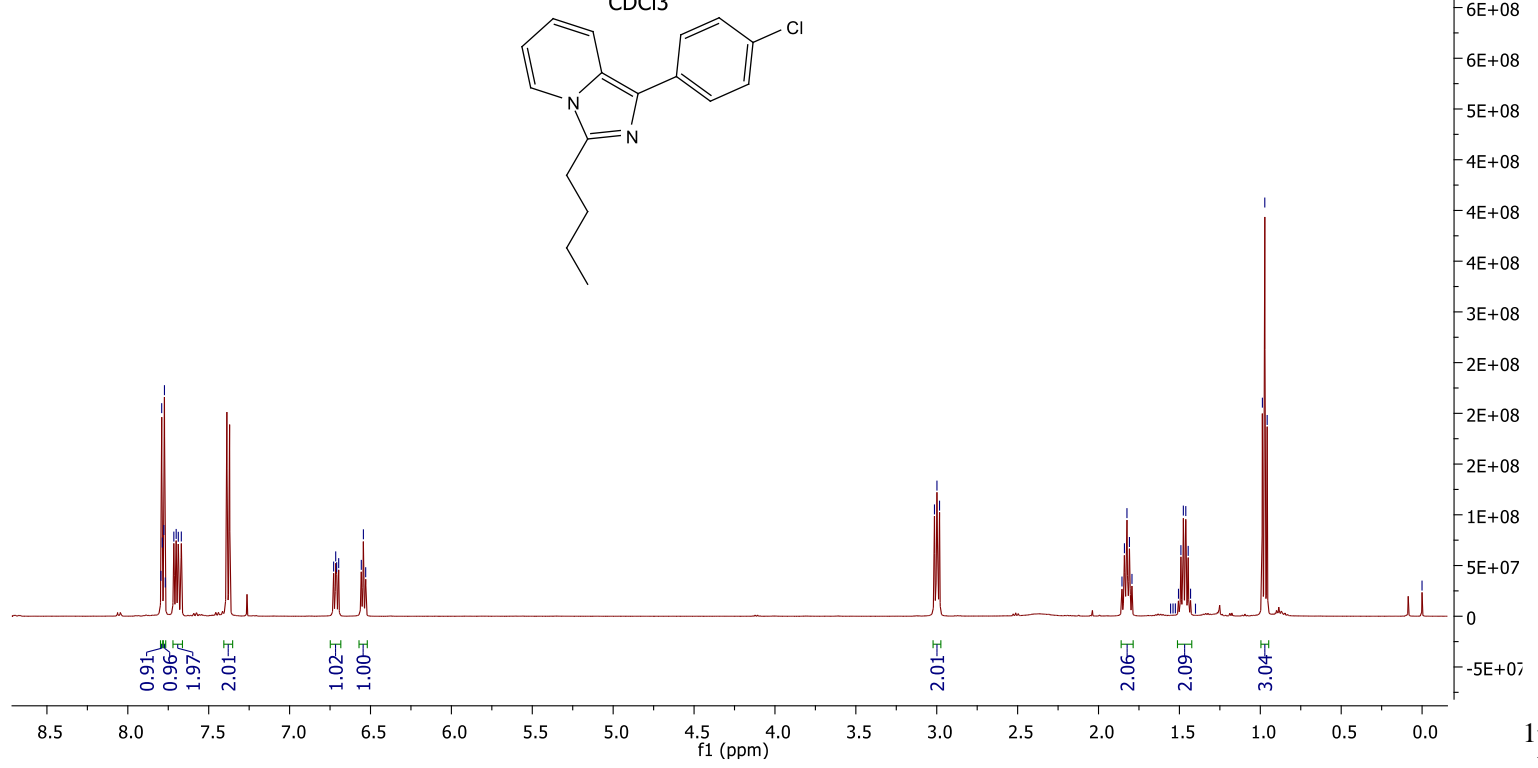

\section{NMR of 3af}

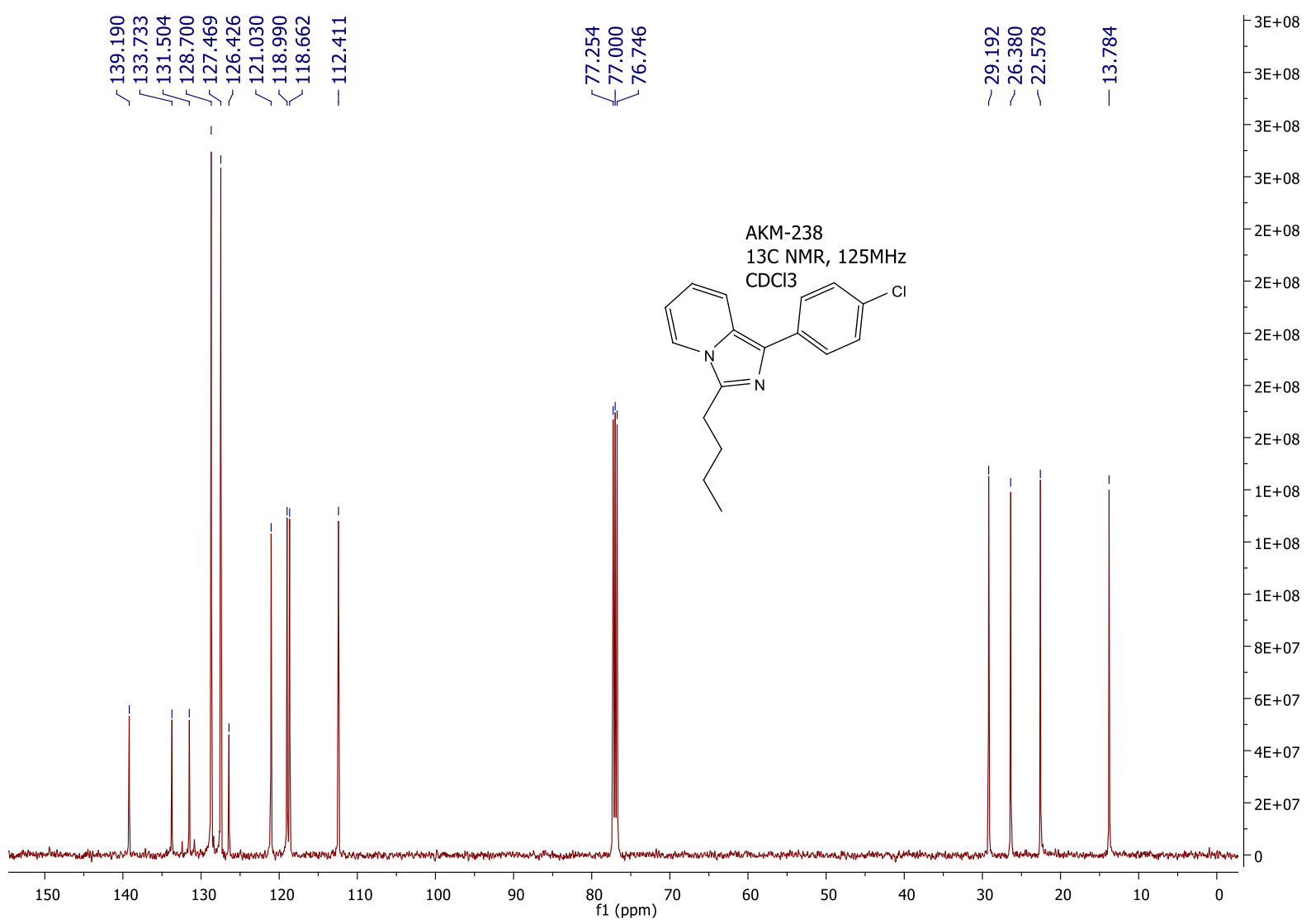

${ }^{13} \mathrm{C}$ NMR of $\mathbf{3 a f}$ 


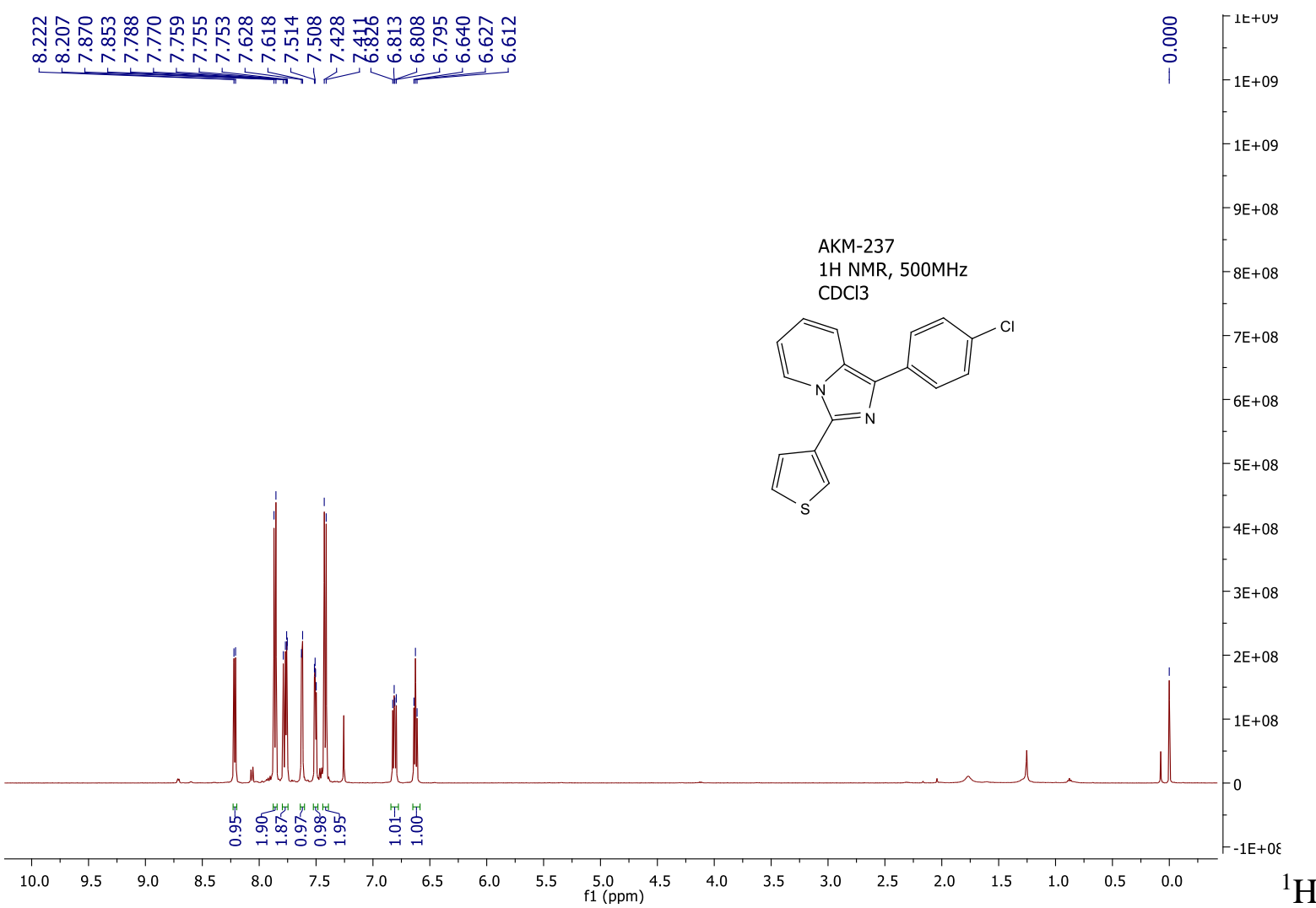

\section{NMR of 3ag}

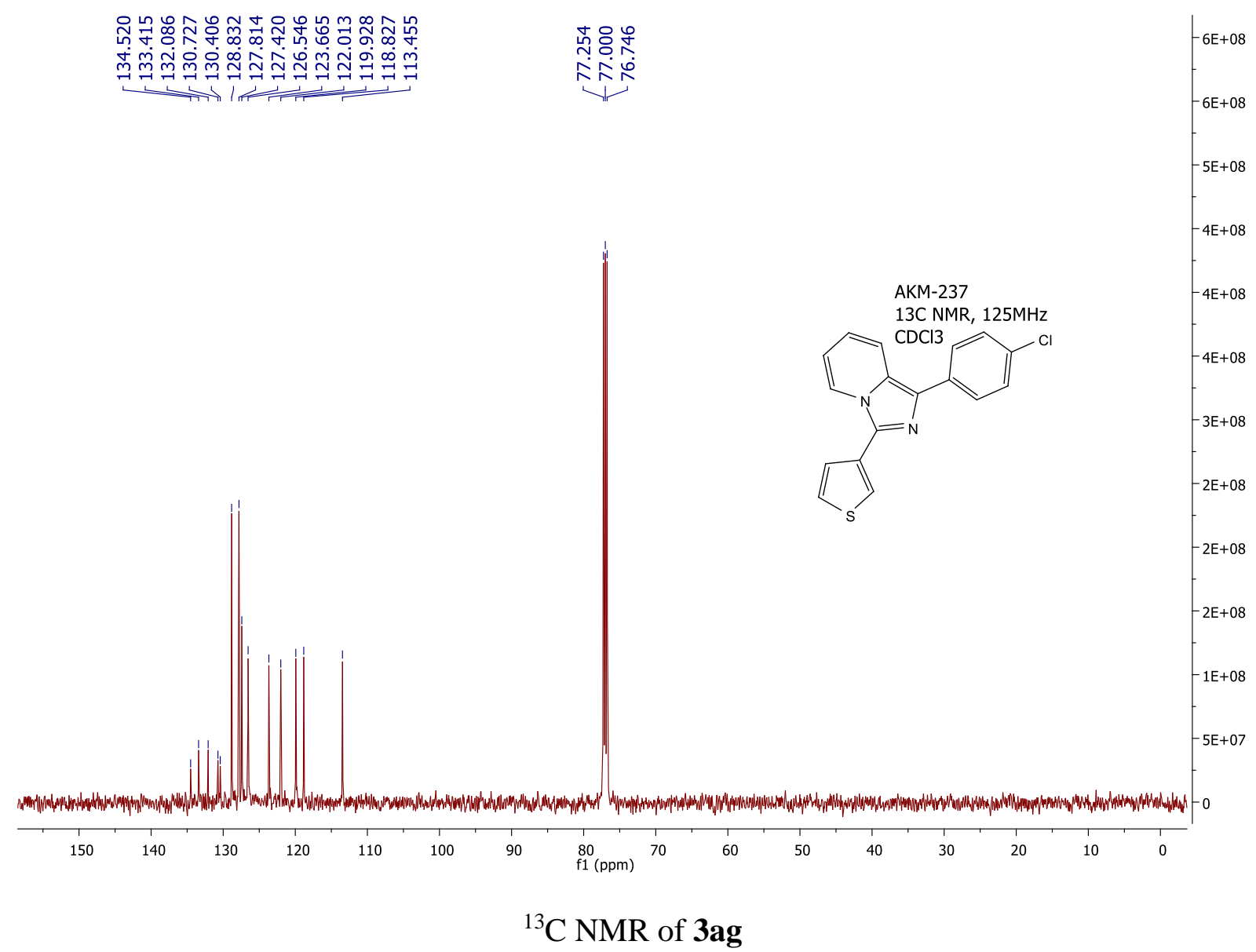



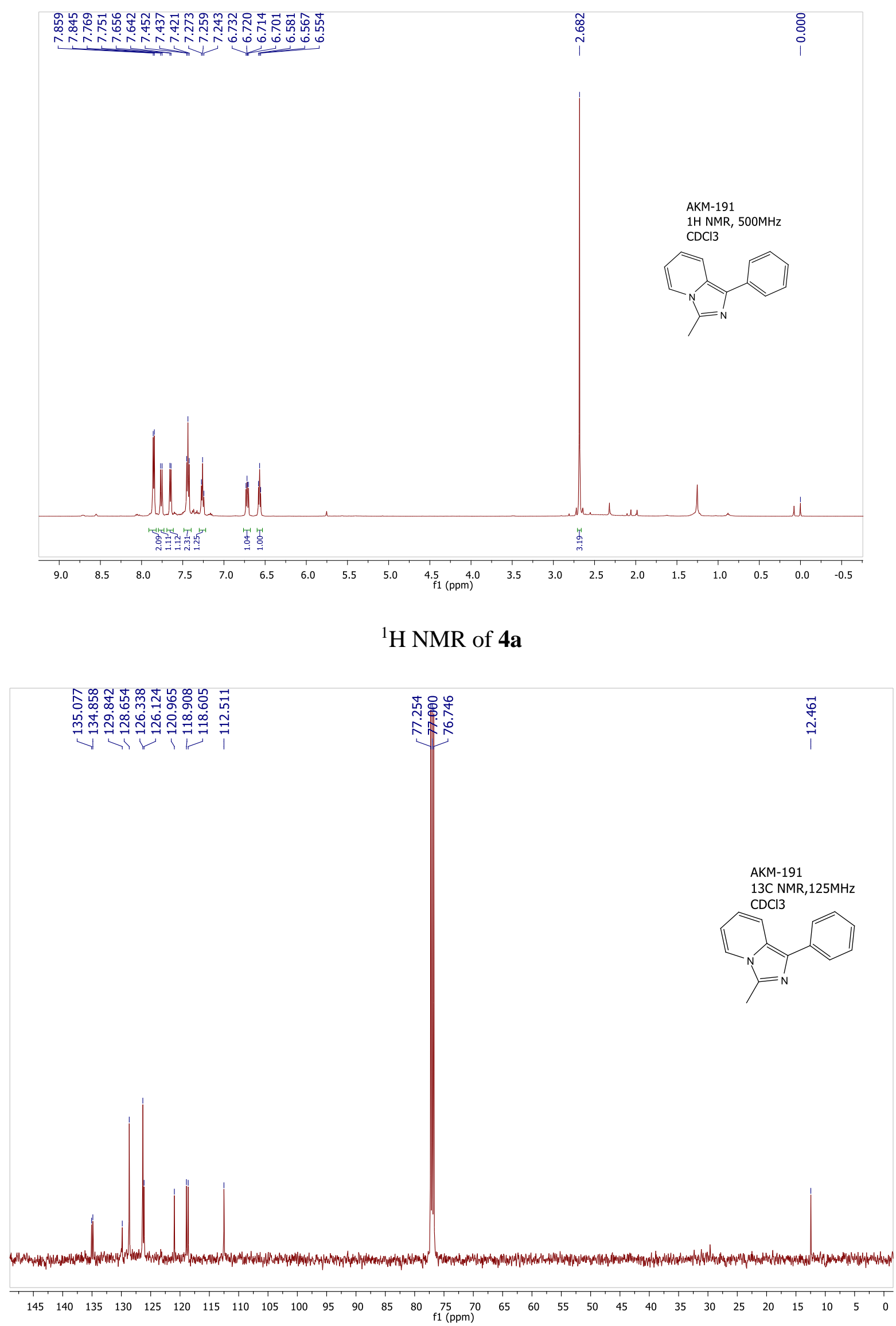

${ }^{13} \mathrm{C}$ NMR of $4 a$ 


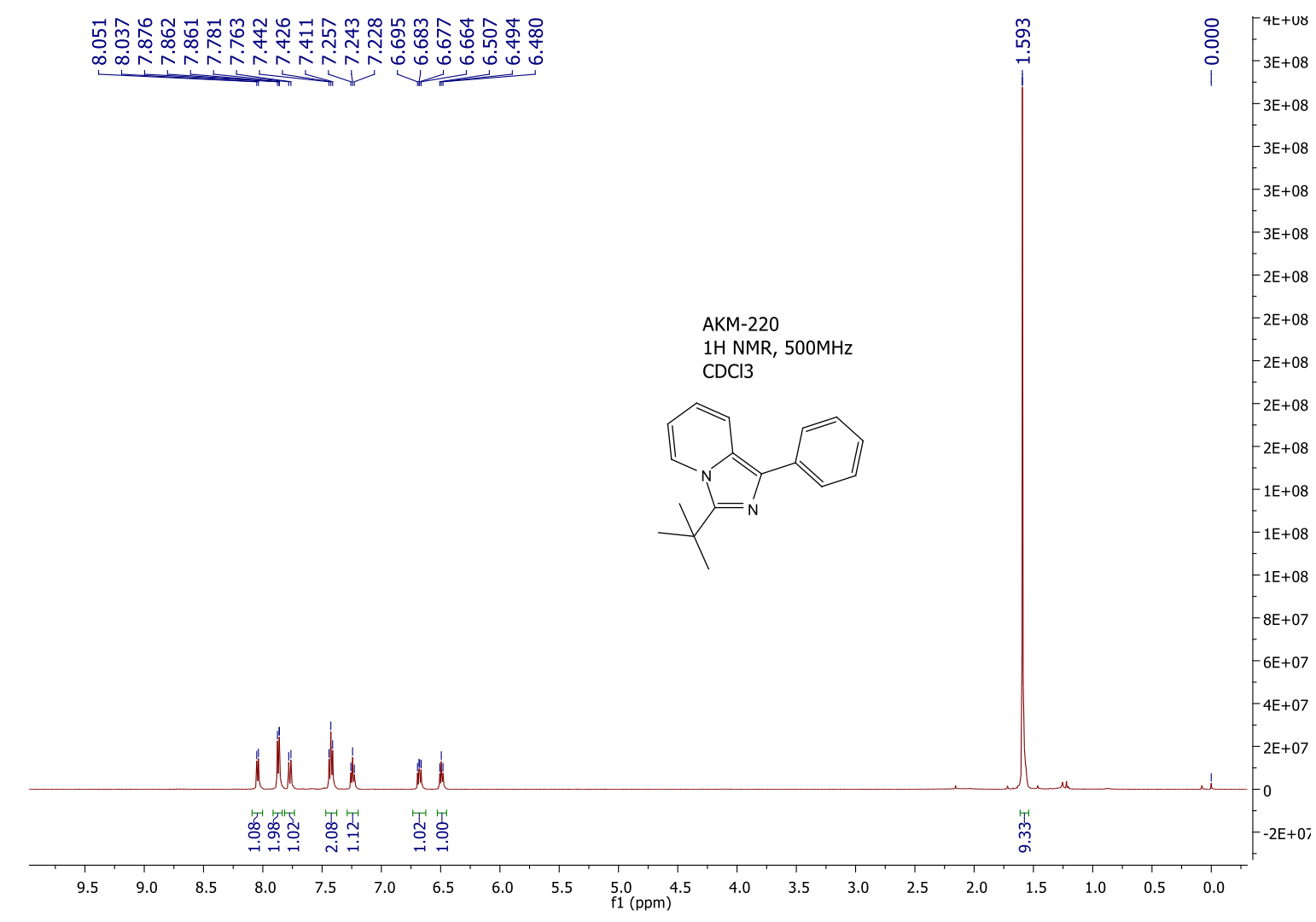

${ }^{1} \mathrm{H}$ NMR of $\mathbf{4 b}$

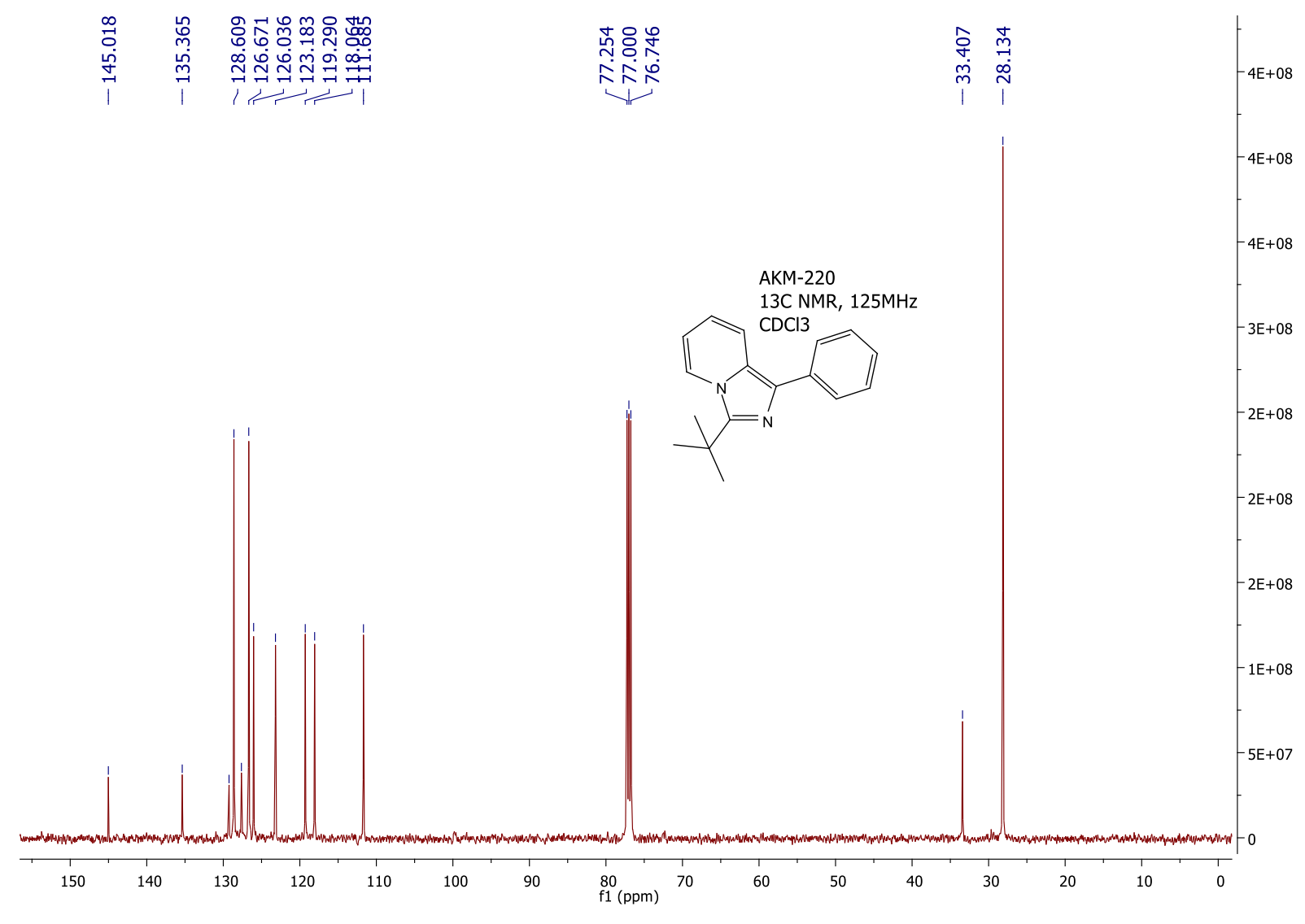

${ }^{13} \mathrm{C}$ NMR of $\mathbf{4 b}$ 


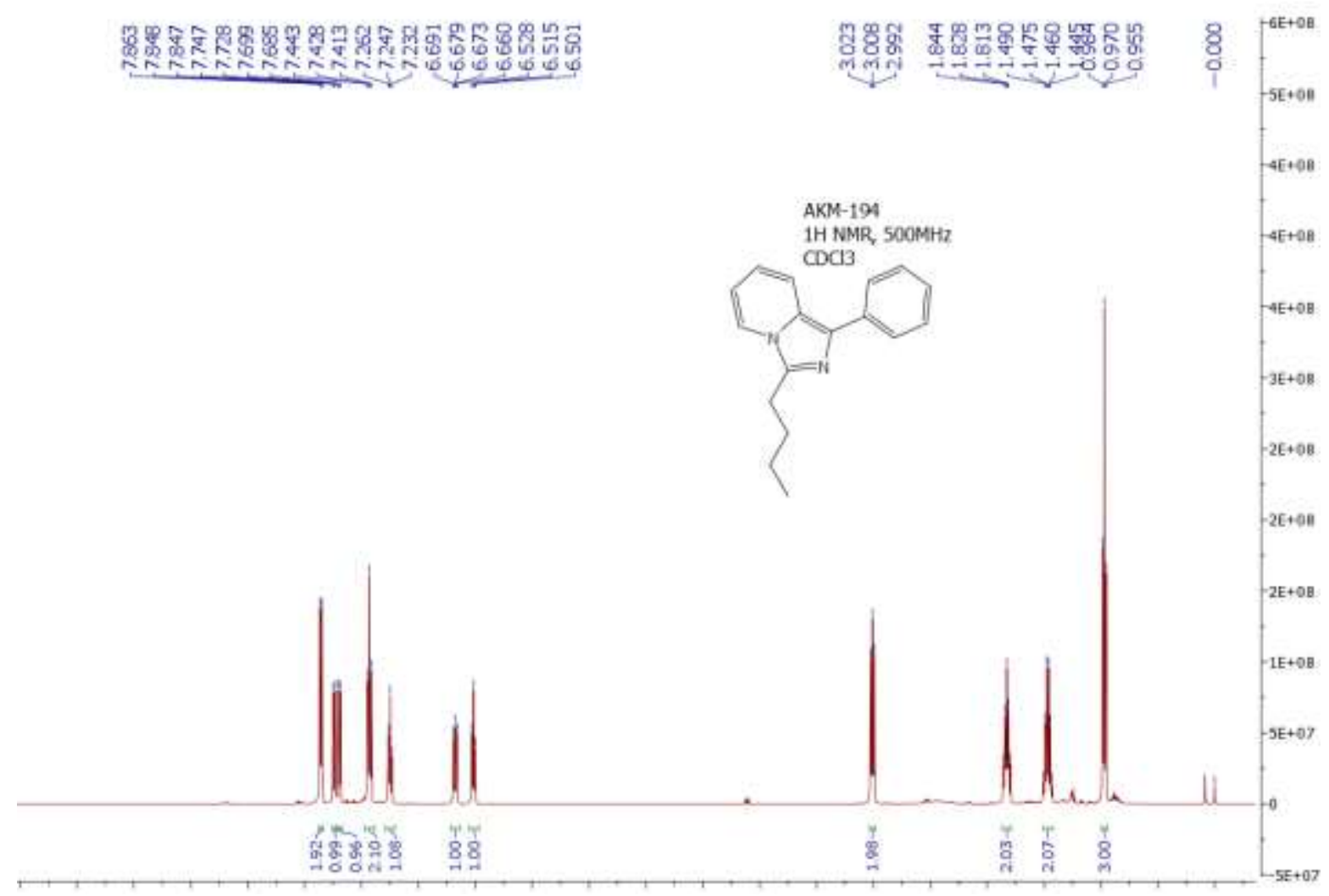

1H NMR of $\mathbf{4 c}$

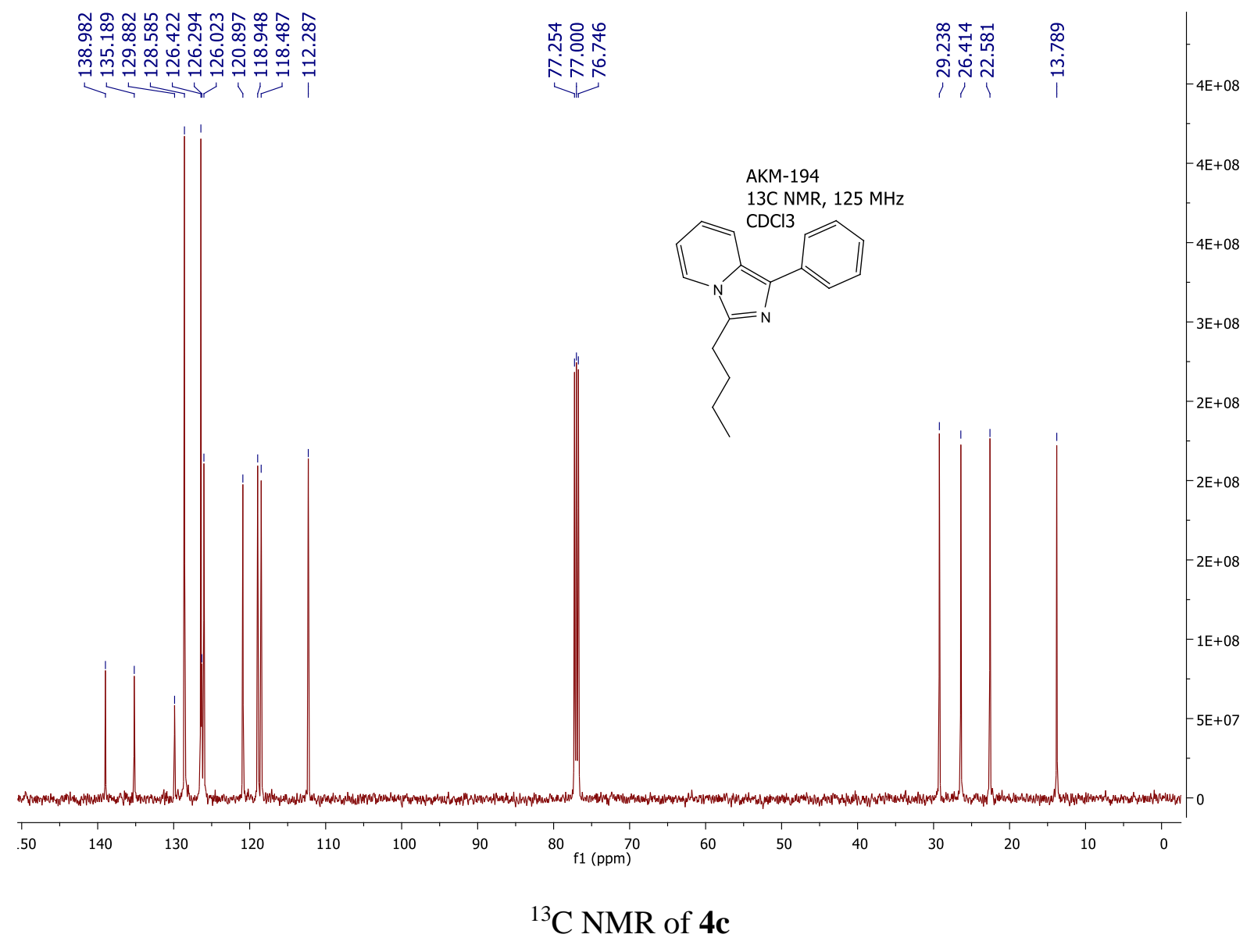




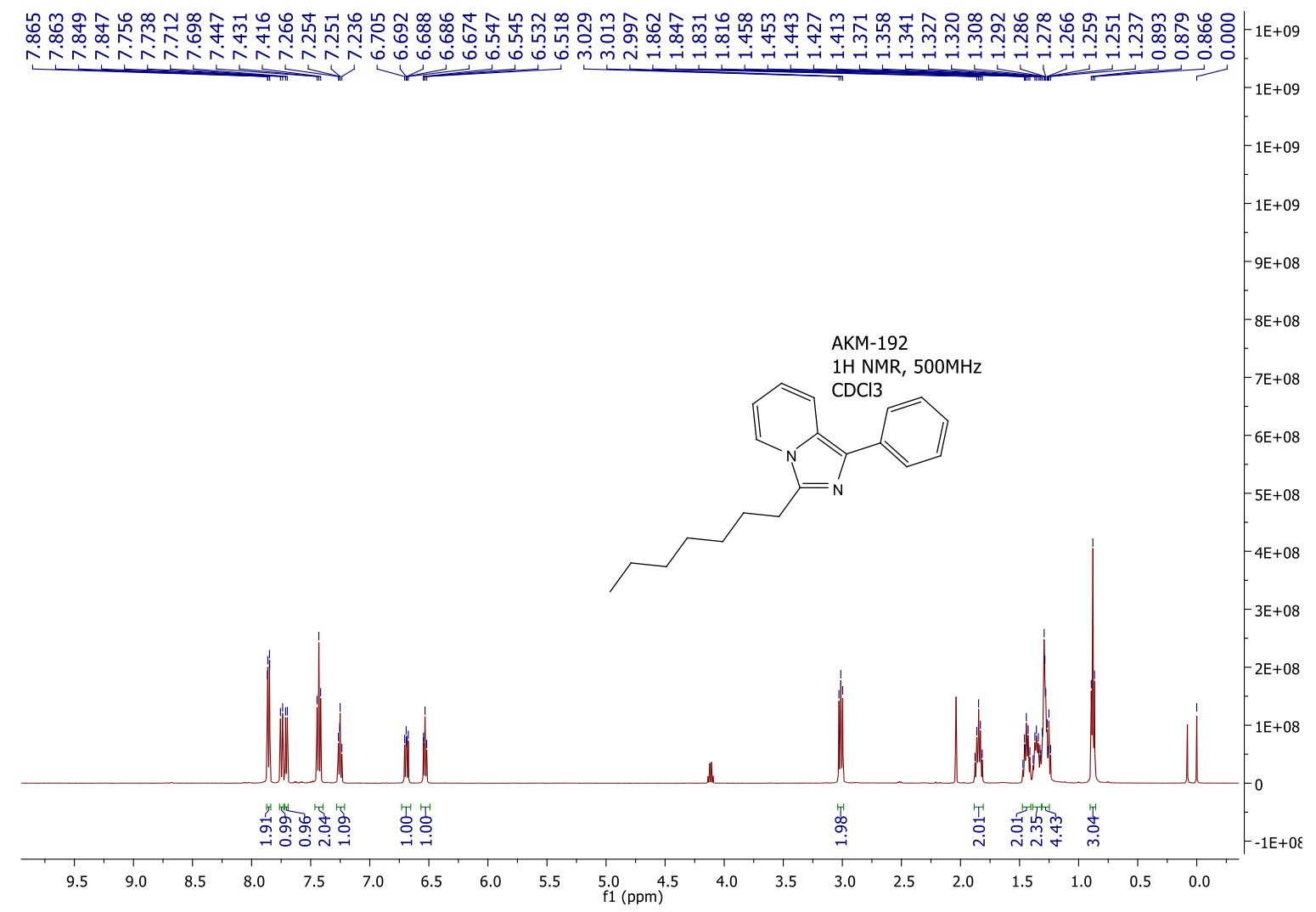

${ }^{1} \mathrm{H}$ NMR of 4d

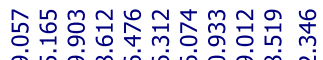

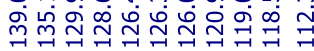

นุํํำ

다유

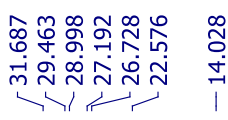

$-8 \mathrm{E}+08$

पा।

Ir

$-7 E+08$

$6 \mathrm{E}+08$

$-6 \mathrm{E}+08$

AKM-192

13C NMR, $125 \mathrm{MHz}$

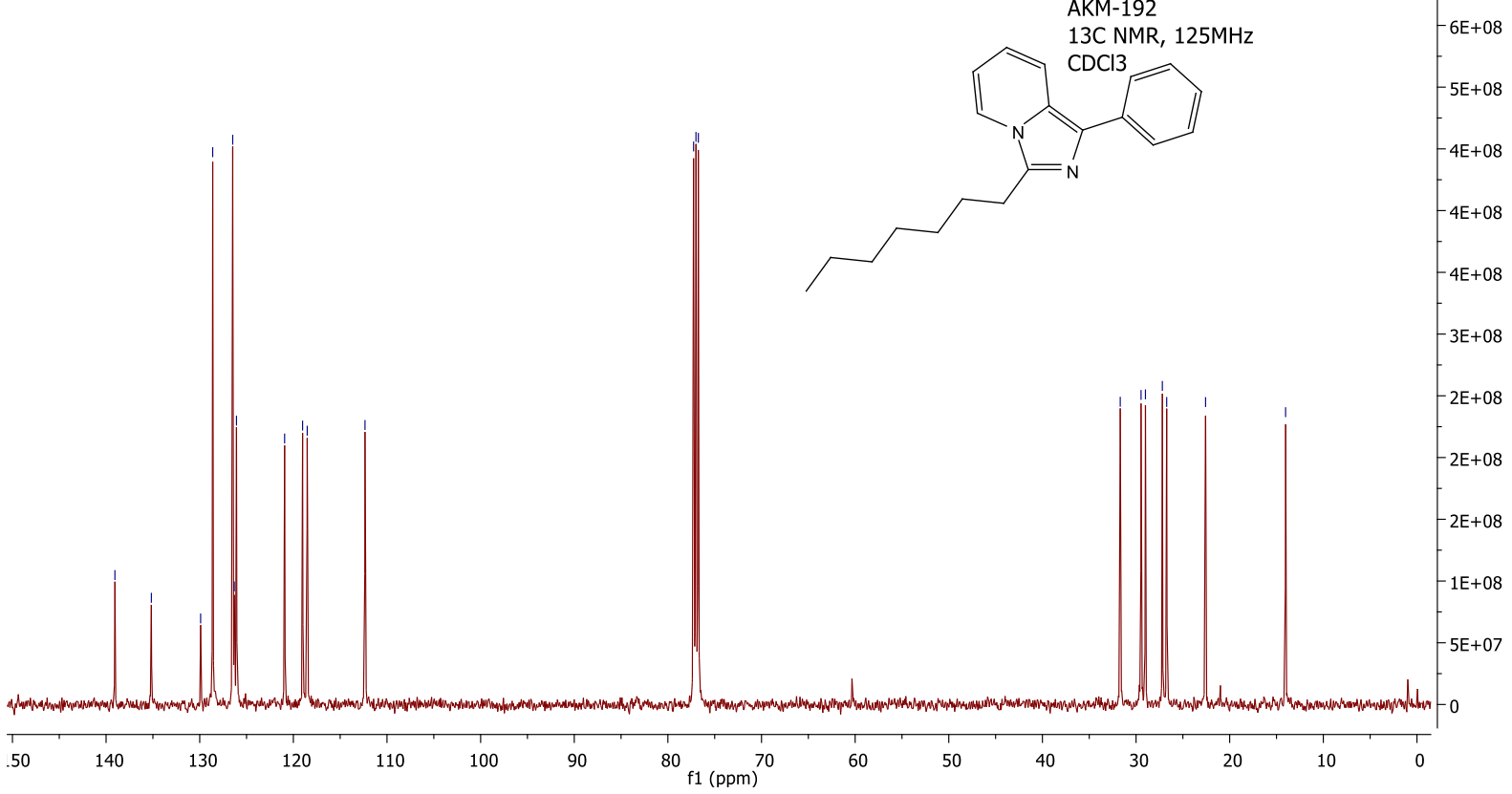

${ }^{13} \mathrm{C}$ NMR of $4 d$ 


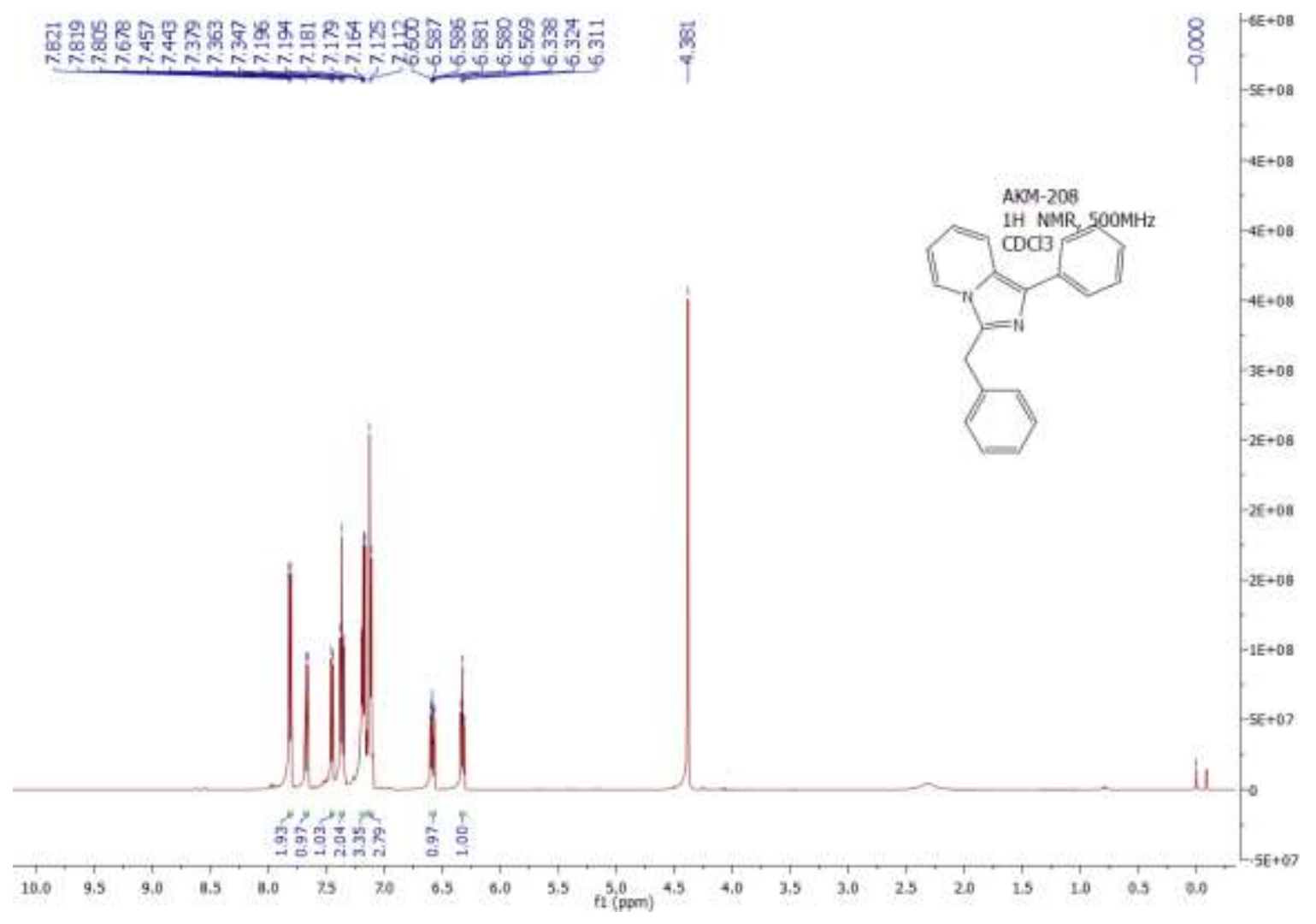

${ }^{1} \mathrm{H}$ NMR of $4 \mathbf{e}$

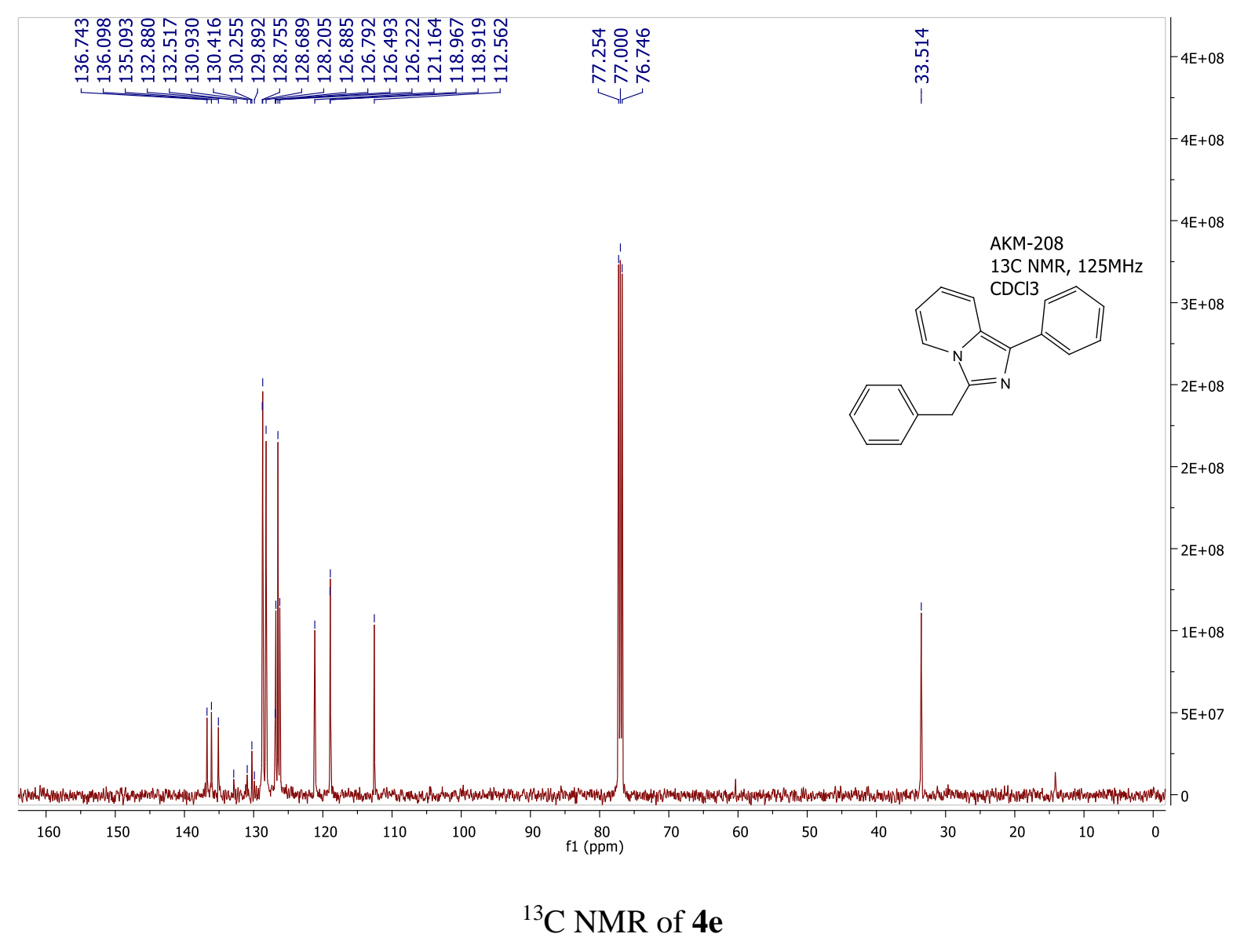




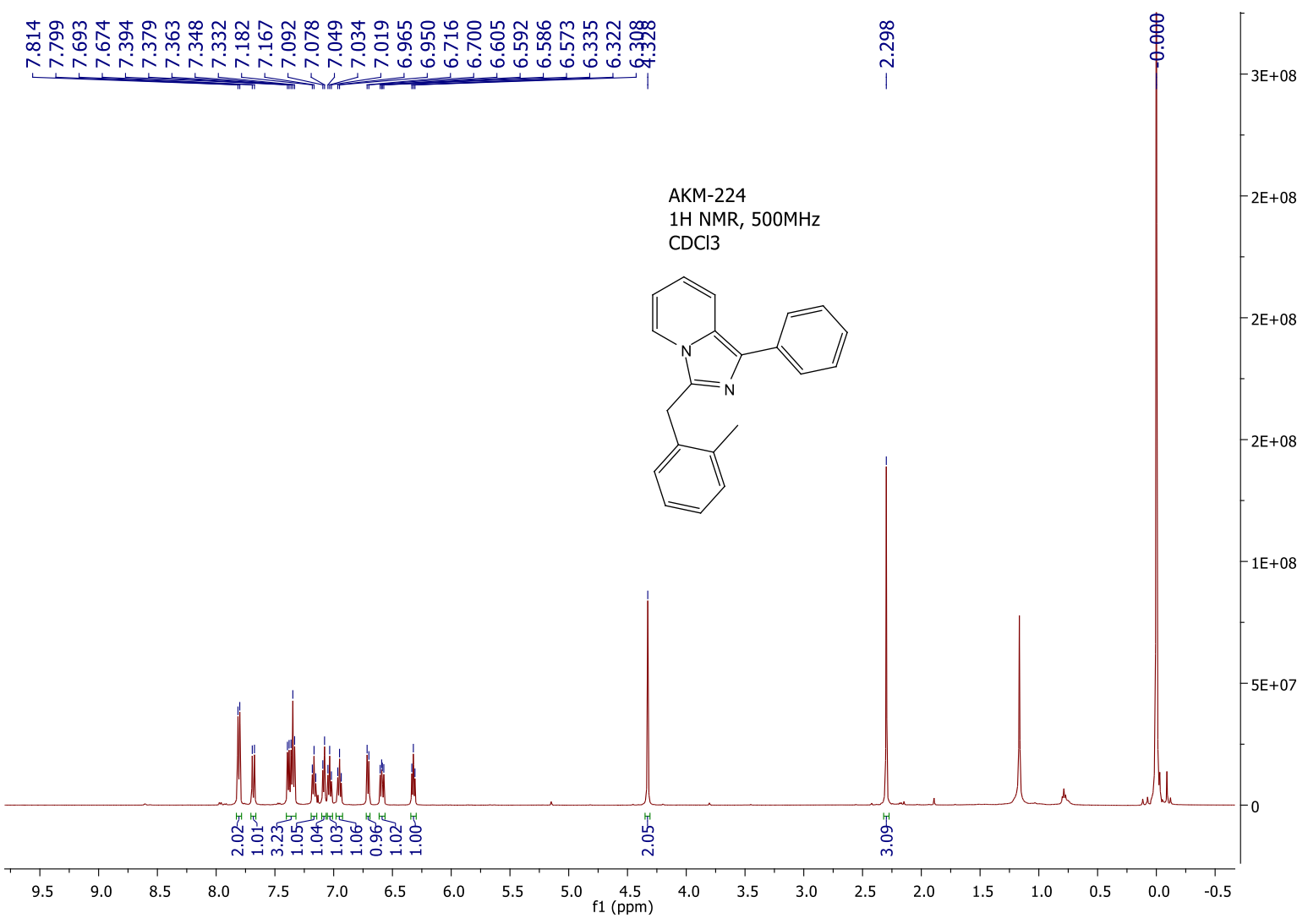

${ }^{1}$ H NMR of $\mathbf{4 f}$

₹

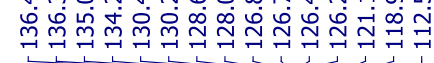

苍号尔

年企
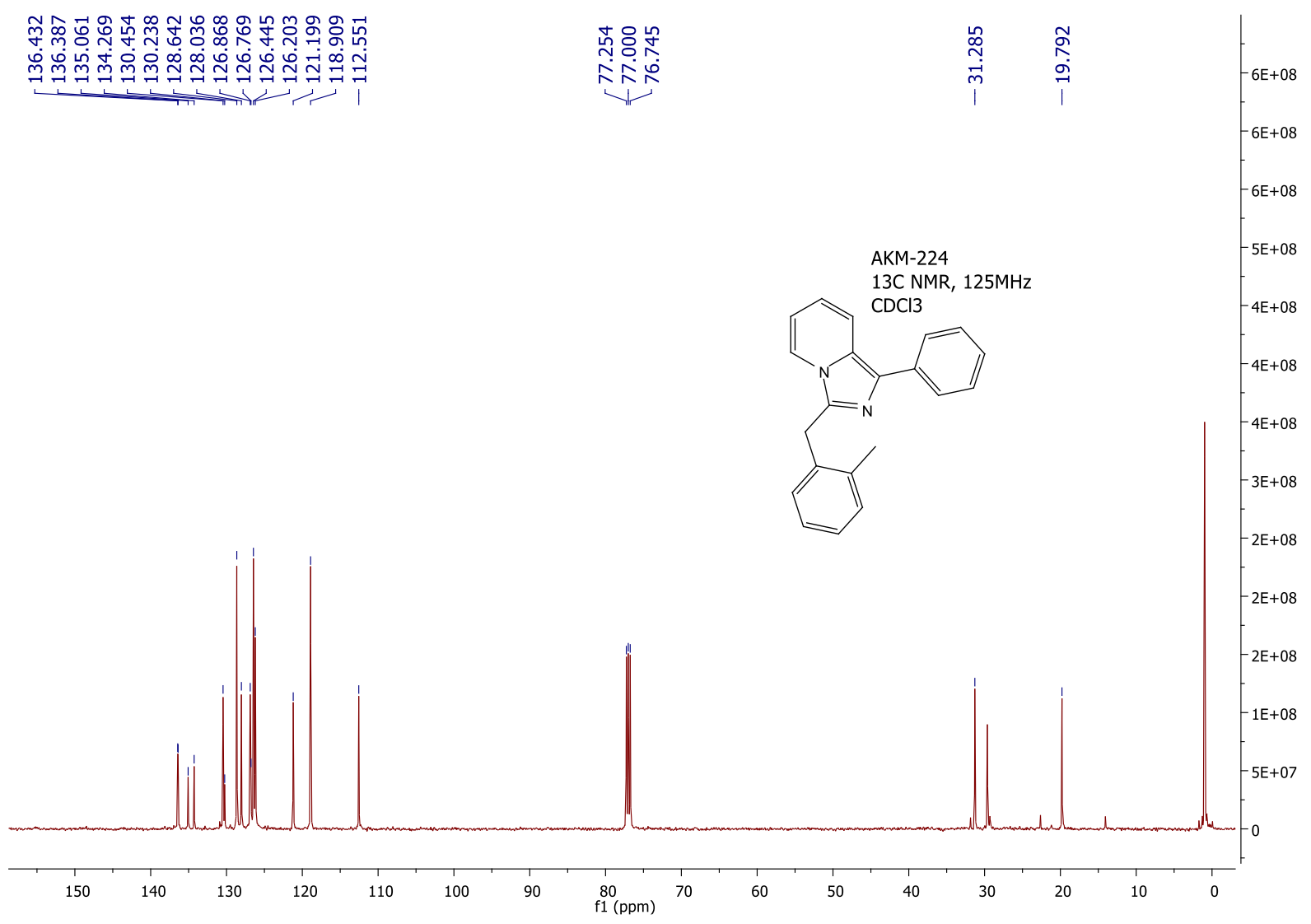

${ }^{13} \mathrm{C}$ NMR of $\mathbf{4 f}$ 
豙余

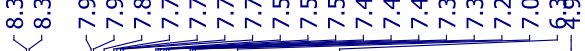

AKM-225

$-2 E+09$

$1 \mathrm{H} \mathrm{NMR,} 500 \mathrm{MHz}$

$\mathrm{CDCl} 3$

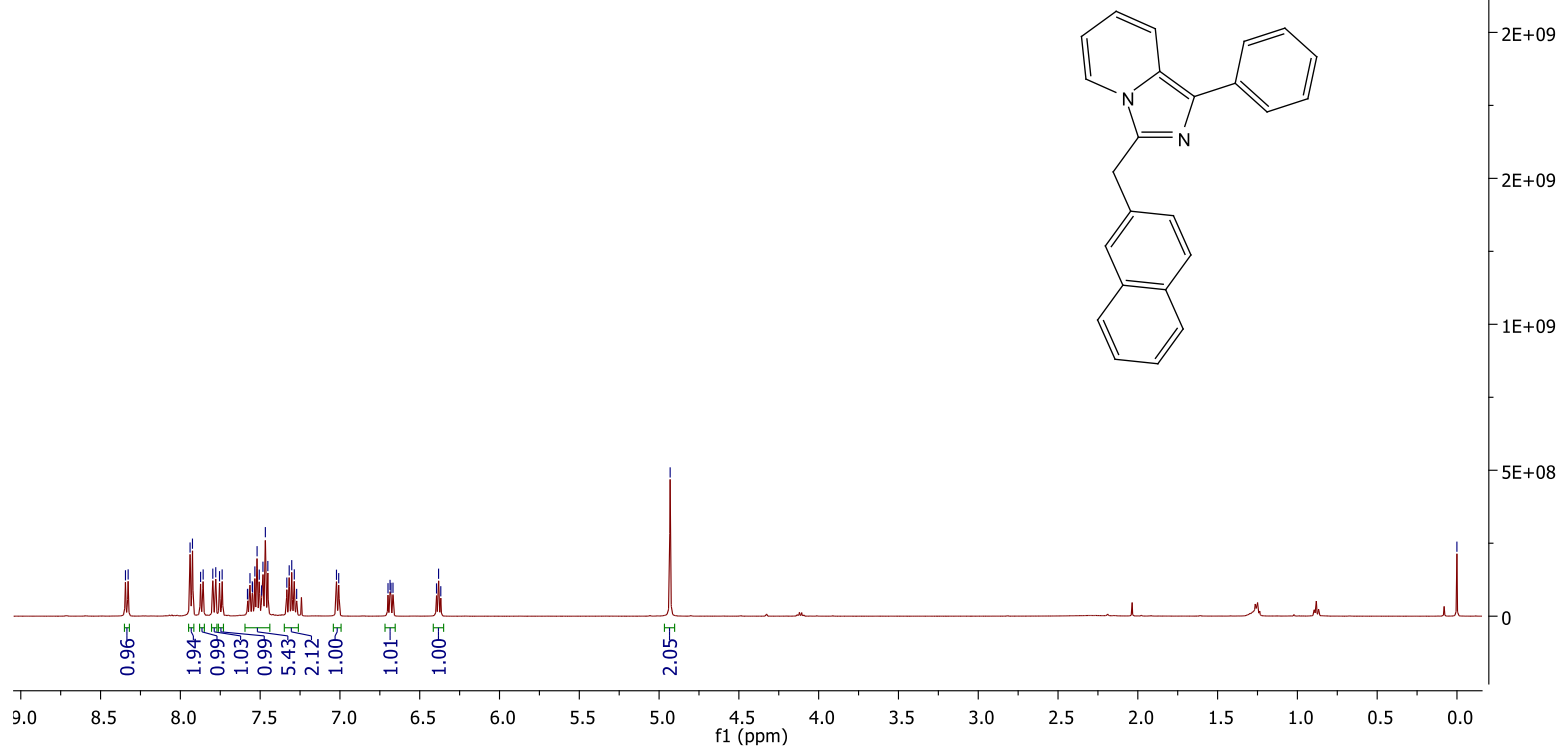

${ }^{1} \mathrm{H}$ NMR of $\mathbf{4 g}$

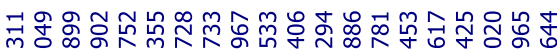

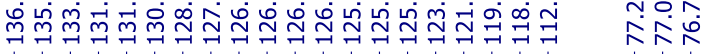

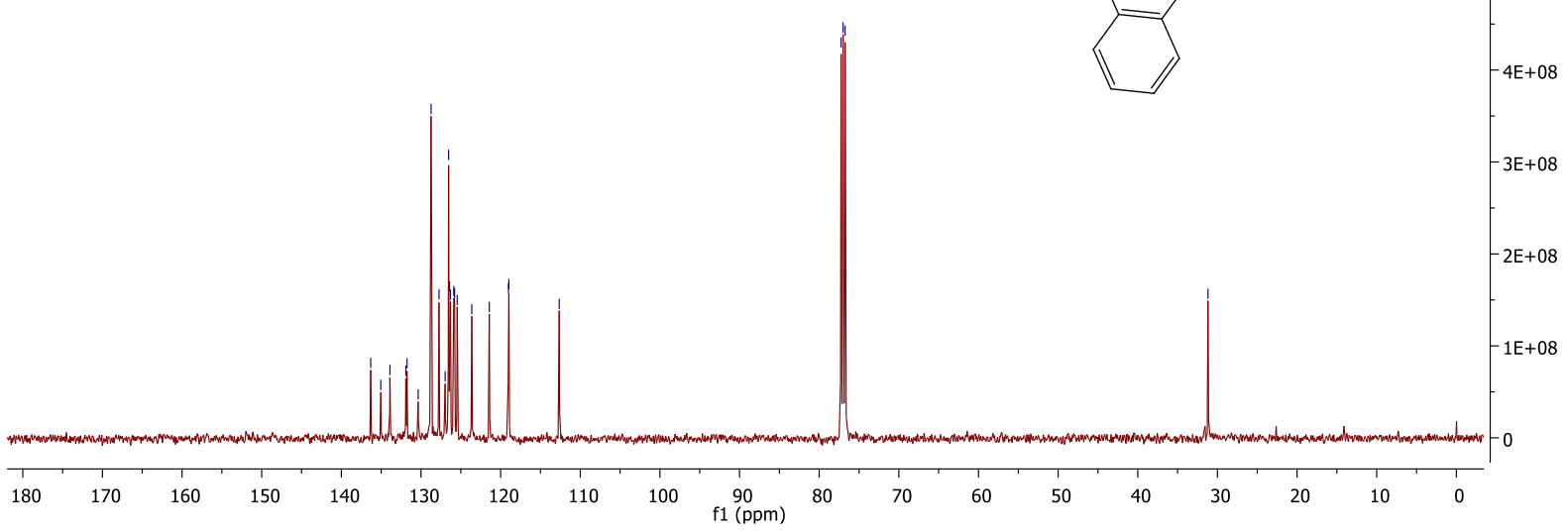

${ }^{13} \mathrm{C}$ NMR of $\mathbf{4 g}$ 


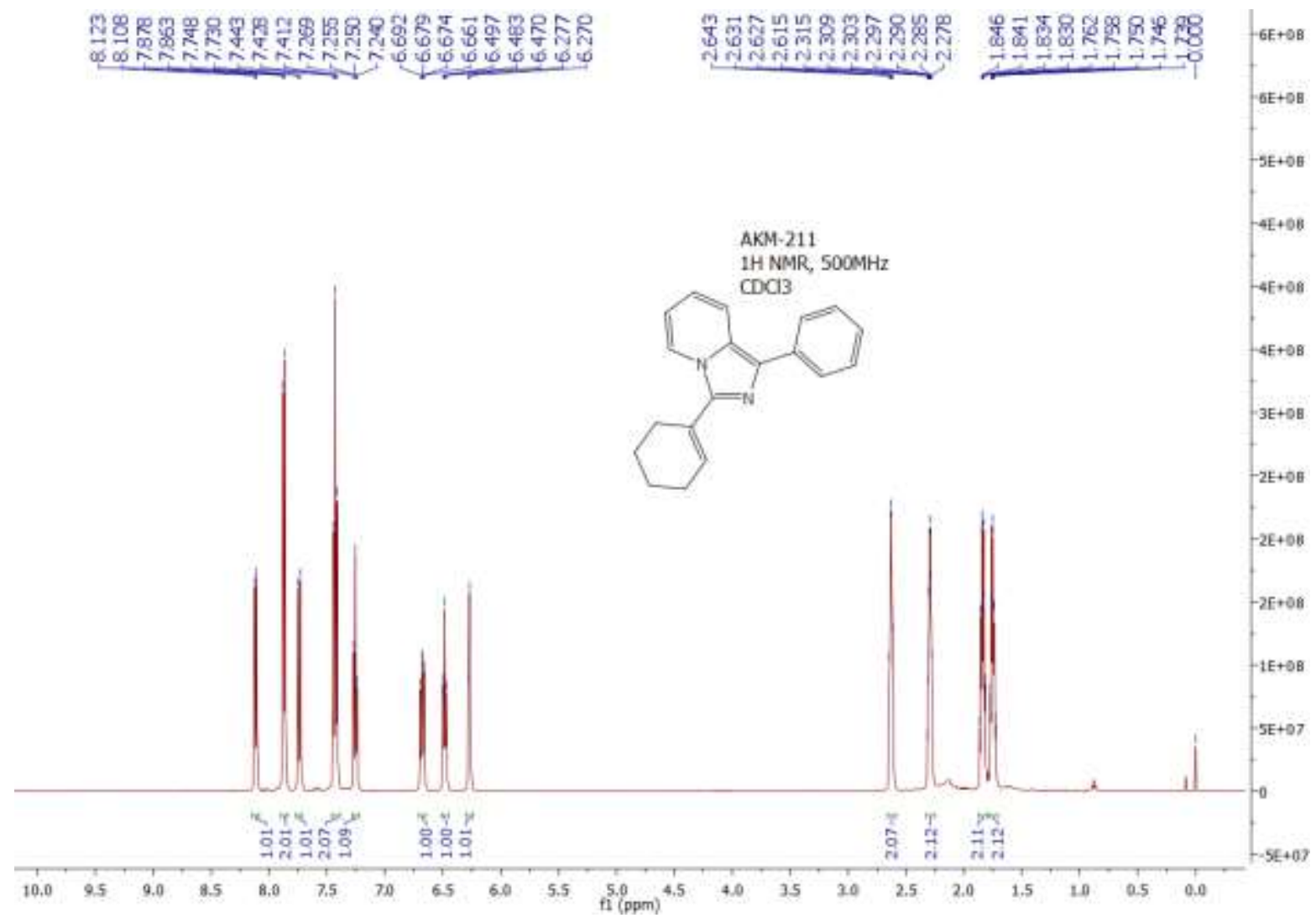

\section{${ }^{1} \mathrm{H}$ NMR of $\mathbf{4 h}$}

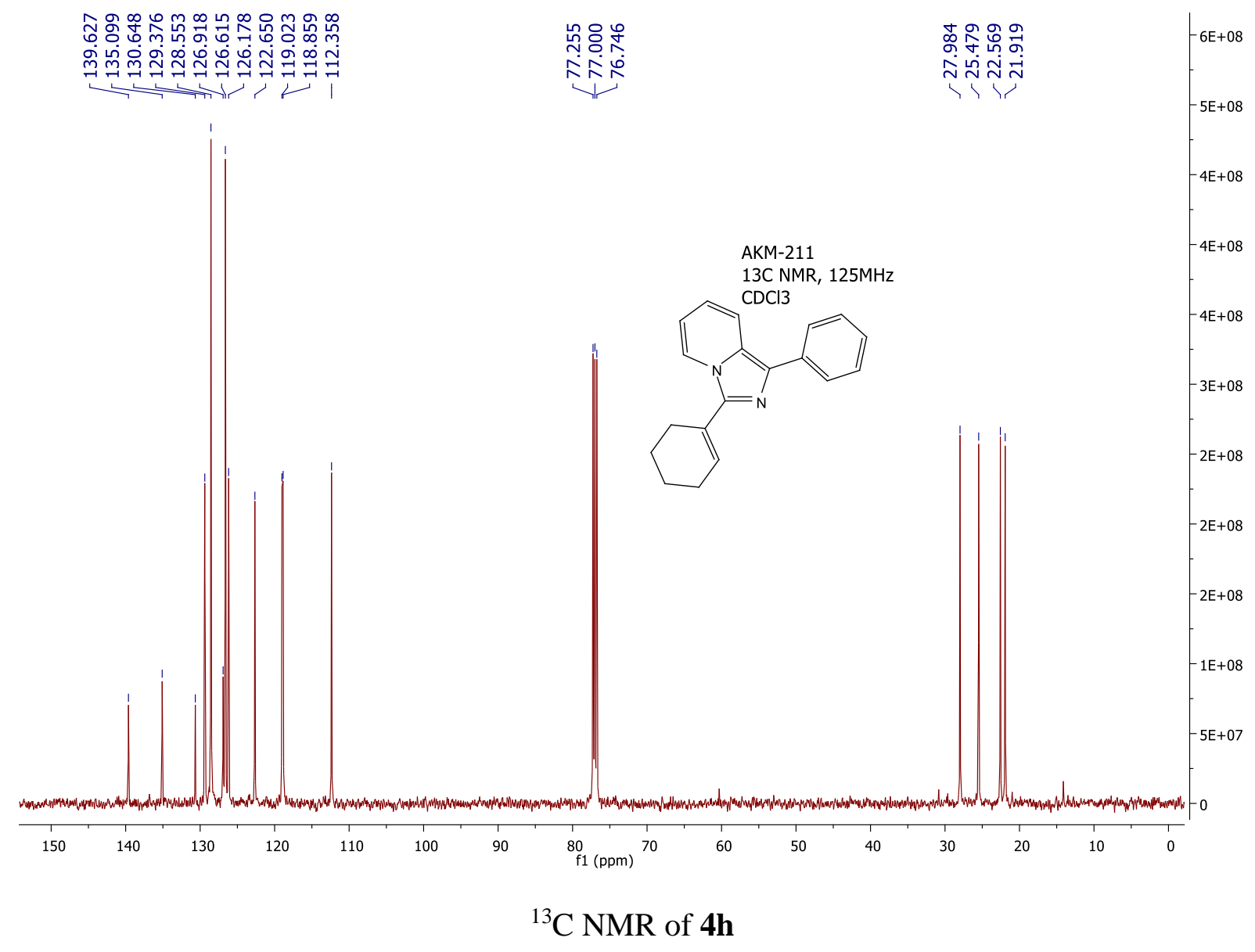




\section{HRMS Spectra for New Compounds}


Single Mass Analysis

Tolerance $=50.0 \mathrm{PPM} / \mathrm{DBE} \min =-1.5, \max =50.0$

Element prediction Off

Number af isotope pesks used for i-FIT = 3

Monoisotopic Mass, Even Election lons

5 formula (e) evaluated weh 1 results wehn limes (up to 50 closest results for each mass

Elements Used. $0.20 \quad \mathrm{H} \mathrm{O.14} \quad \mathrm{N} .0 .2$ Br 0.1

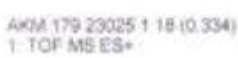

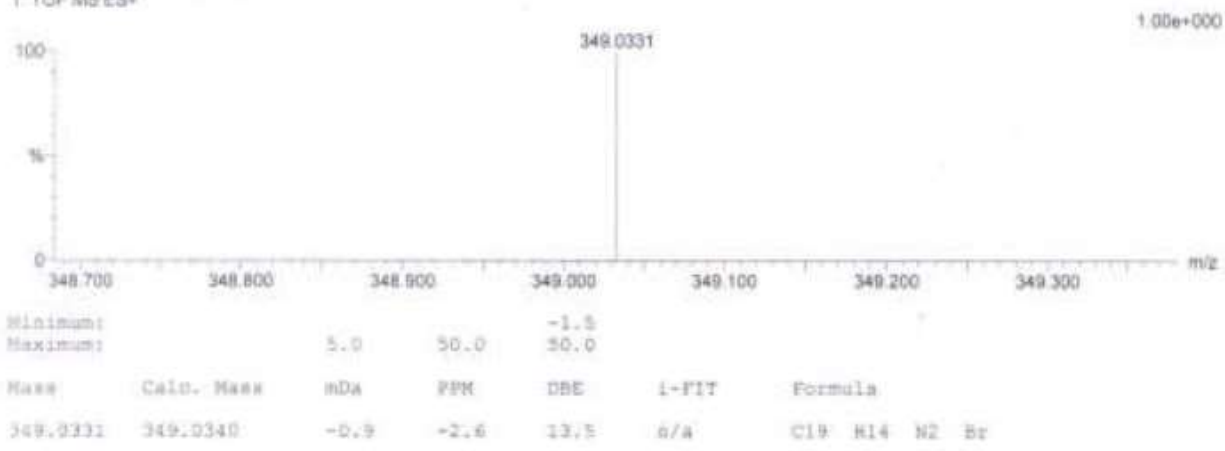

\section{HRMS of 3d}

Elemental Composition Report

Page 1

Single Mass Analysis

Tolerance $=50.0$ PPM $/$ DBE: $\min =-1.5, \max =50.0$

Element prediction: Off

Number of isotope peaks used for $1-F I T=3$

Monosotopic Mass, Even Electren ions

4 formula(e) evaluated with 1 results within limits (up to 50 ciosest results for each mass)

Elements Used

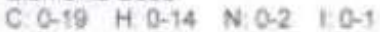

AKCM 15? 203 $12(0.223)$

1. TOF MSES.

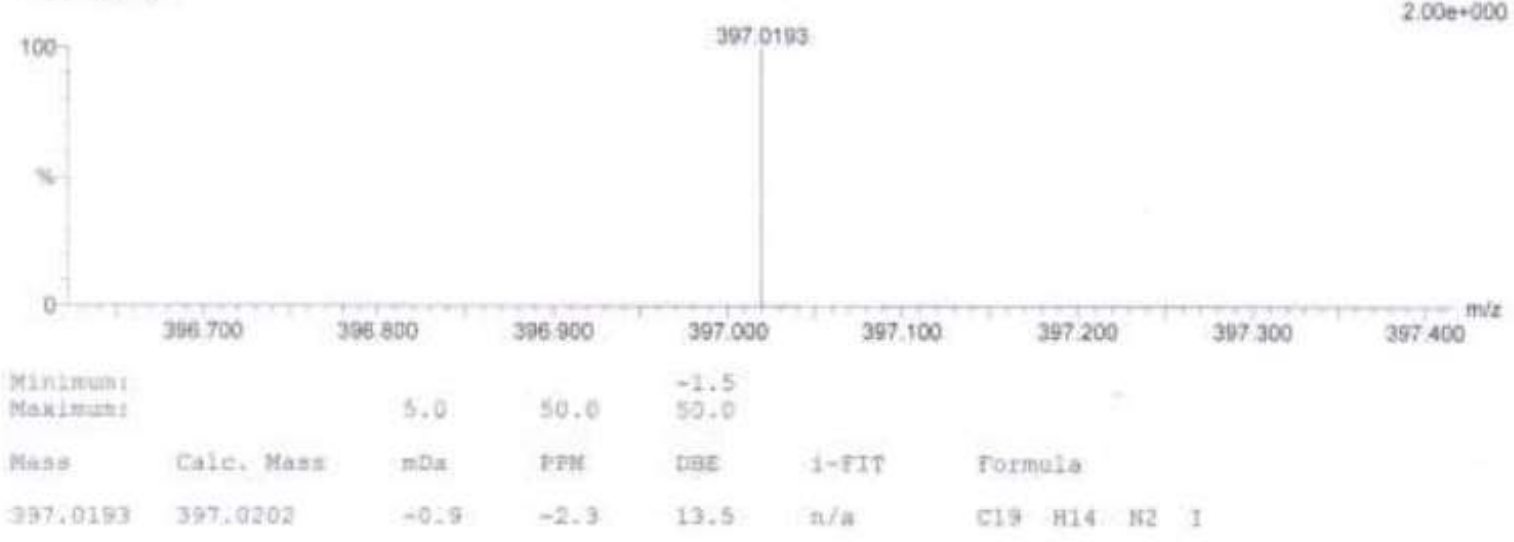

HRMS of $3 g$ 
Single Mass Analysis

Tolerance $=50.0$ PPM, DBE $\min =-1.5, \max =50.0$

Element prediction Off

Number of isotope peaks used for $\mathrm{H}-\mathrm{FIT}=3$

Monoisotopic Mass. Even Electron lons

8 formula(e) evaluated with 1 resuits within limits (up to 50 closest results for each mass)

Elements Used

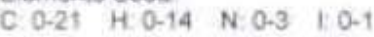

AKOA 20733317 10.315:

1 TOF MS ES.

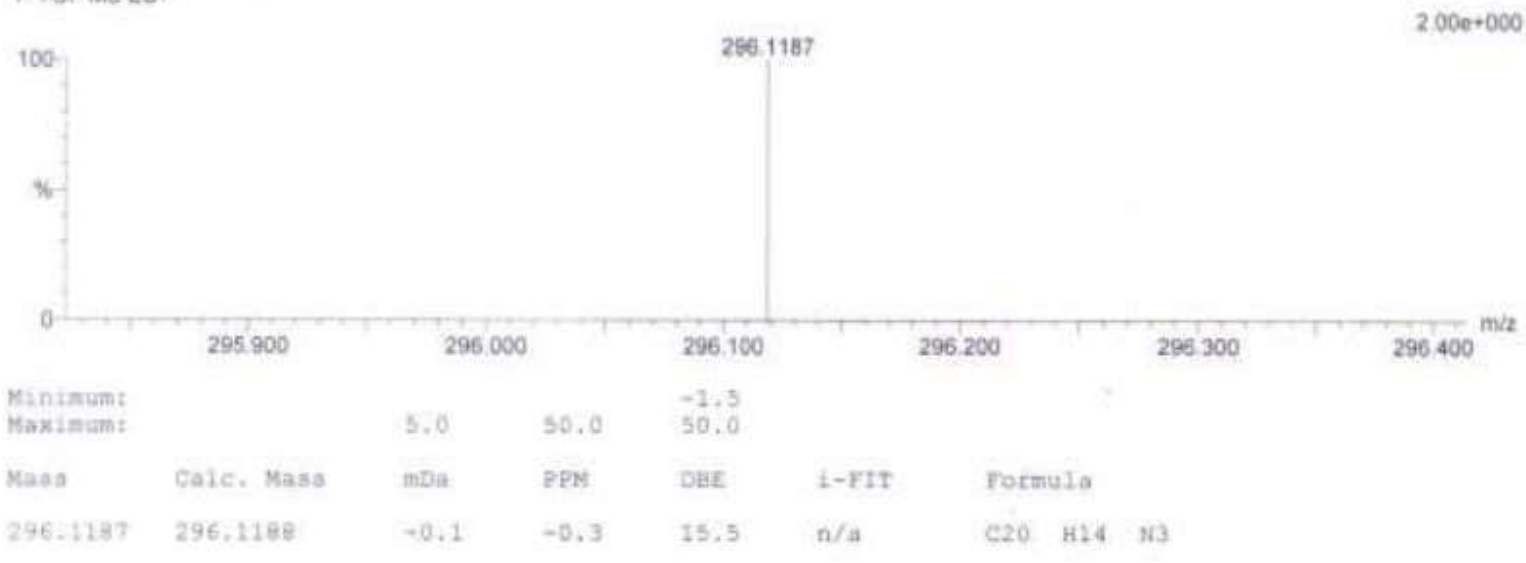

\section{HRMS of $3 \mathbf{j}$}

\section{Elemental Composition Report}

\section{Single Mass Analysis}

Tolerance $=50.0$ PPM / DBE $\min =-1.5 . \max =50.0$

Element prediction: Off

Number of isotope peaks used for $\mathrm{i}-\mathrm{FIT}=3$

Monoiesotopic Mass, Even Electron lons

9 formula(e) evaluated with 1 results within limits (up to 50 closest results for each mass)

Elements Used

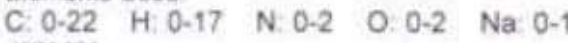

AKM 232

AKM 23278 (1 010

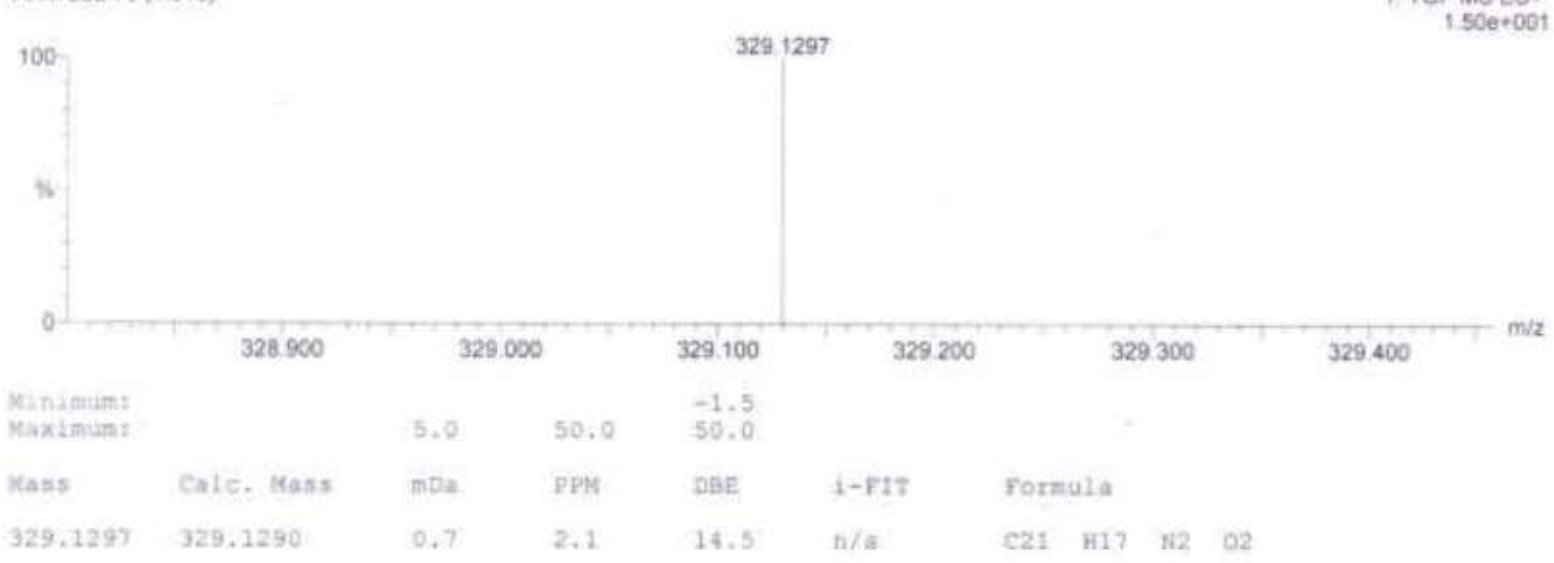

\section{HRMS of 3k}


Single Mass Analysis

Tolerance $=50.0 \mathrm{PPM} / \mathrm{DBE} \min =-1.5, \max =50.0$

Element prediction Off

Number of isotope peaks used for i-FIT $=3$

Monoisotopic Mass. Even Electron lons

4070 formula(e) evaluated with 35 results within limits (up to 50 closest results for each mass)

Eiements Used

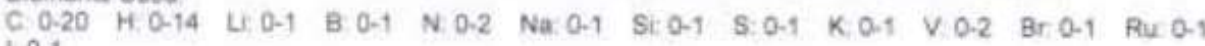

10.1

AXM 178 SB $(0$ 689

1. TOF MSES.

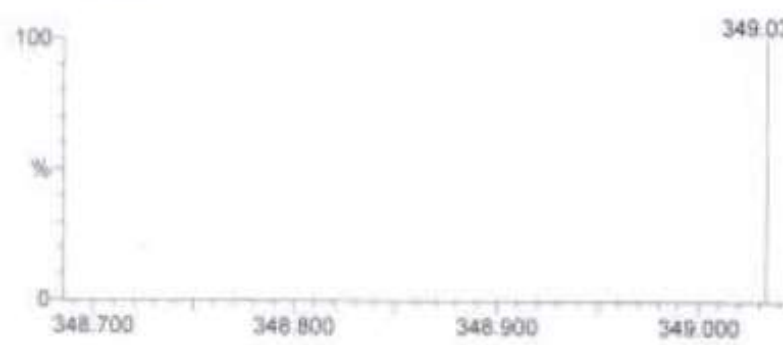

$1.000 \cdot 000$

Mininiati:

Maximin

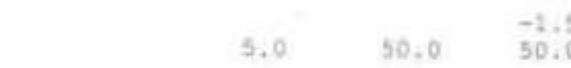

Sas:

\section{HRMS of 3n}

\section{Elemental Composition Report}

\section{Single Mass Analysis}

Tolerance $=50.0$ PPM, DEE: $\min =-1.5, \max =50.0$
Element prediction: Off

Number of isotope peaks used for $1-\mathrm{FIT}=3$

Monoisotopic Mass, Even Eloctron lons

4070 formula(e) evaluated with 35 results within limits (Up to 50 closest resuits for seach mass)

Elements Used

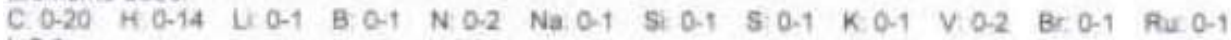

$10-1$

AxM in 67 <0677

1 TOF MS ES.

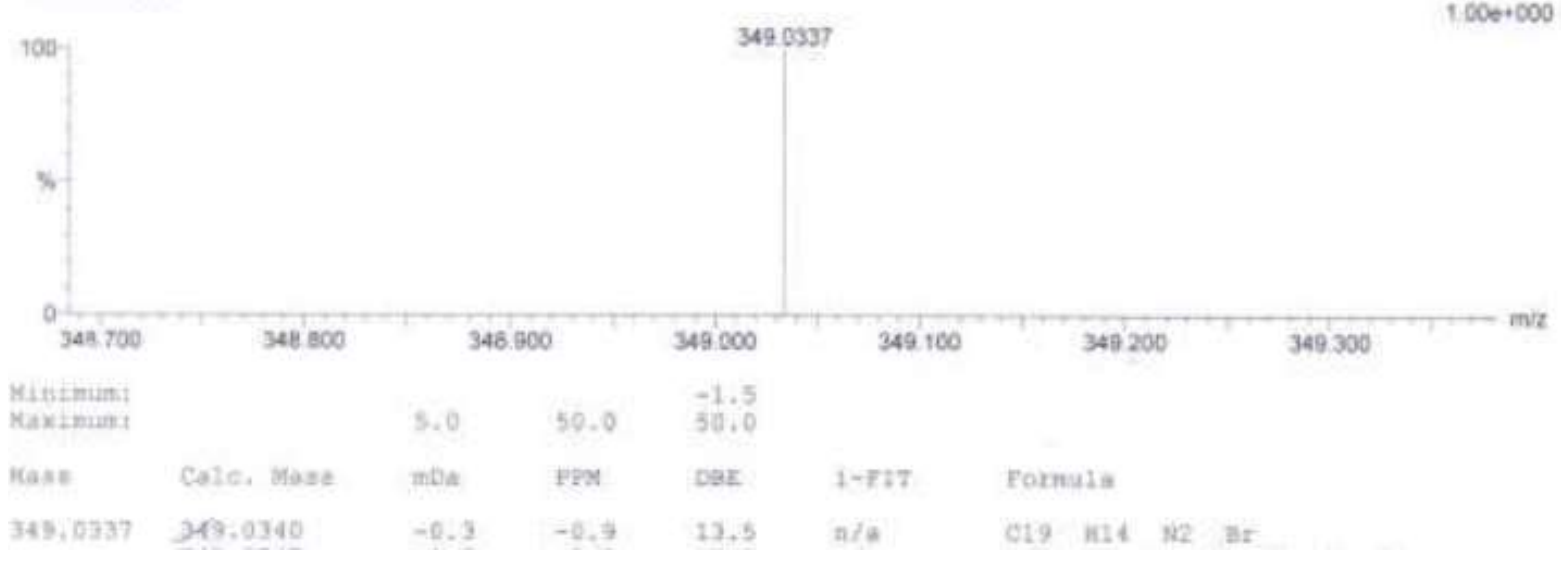

HRMS of 3s 
Single Mass Analysis

Tolerance $=50.0 \mathrm{PPM}, \mathrm{DBE}: \min =-1.5 . \max =50.0$

Element prediction: Off

Number of isotope peaks used for $\mathrm{I}-\mathrm{FIT}=3$

Monoisotopic Mass, Even Electron lons

12 formula(e) evaluated with 1 results within limits fup to 50 closest resuits for each mass)

Elements Used

$\begin{array}{llllll}\text { C: } 0-19 & \text { H: } 0-13 & \text { N: } 0-2 & \mathrm{Na}: 0-1 & \text { Cl } 0-2\end{array}$

AKM 193

AKM $193148(2.174)$

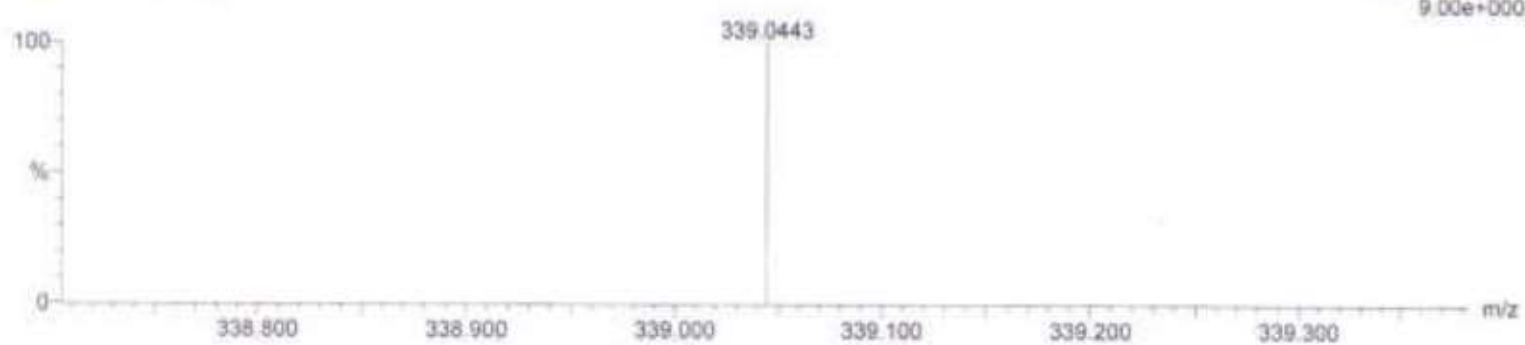

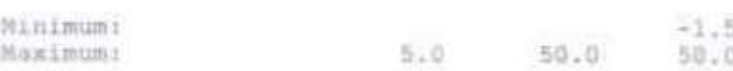

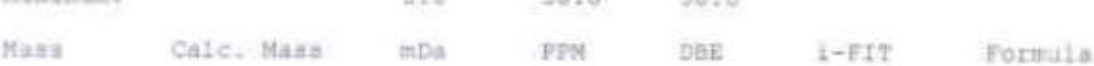

$339.0443 \quad 399.0456 \quad-1.3 \quad-3.8 \quad 13.5 \quad \mathrm{n} / \mathrm{a} \quad$ c19 ins $\mathrm{k2}$ c22

\section{HRMS of 3v}

Elemental Composition Report

Page 1

\section{Sing'e Mass Analysis}

Tolerance $=50.0$ PPM $\quad$ DBE $:$ min $=-1.5 . \max =50.0$

Element prediction: Off

Number of isotope peaks used for $1-F I T=3$

Monoisotopic Mass, Even Electron lons

5 formula(e) evaluated with 1 fesults within limits (up to 50 closest results for each mass)

Elements Used

C: $0.26 \quad$ H: $0-19 \quad \mathrm{~N}: 0-2 \quad \mathrm{Na}: 0.1$

AKM 18953 (0.883)

1: TOF MS ES.

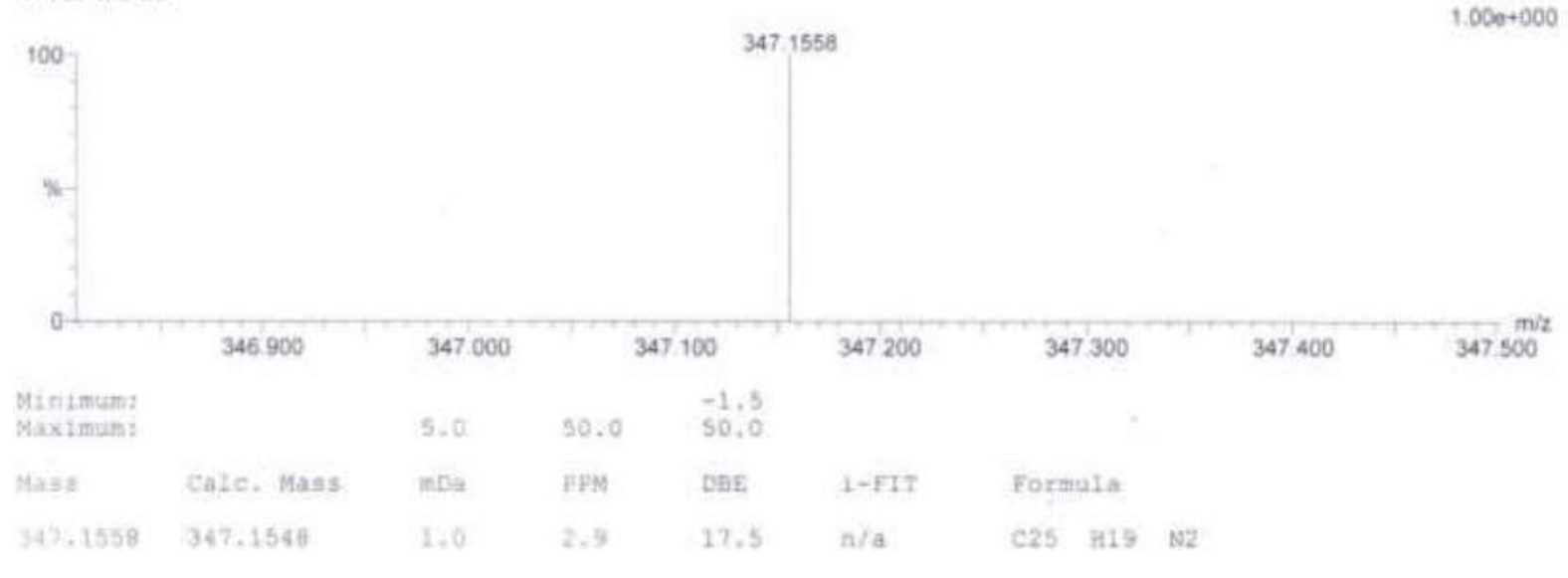

\section{HRMS of 3w}


Single Mass Analysis

Tolerance $=50.0$ PPM / DBE $\min =-1.5, \max =50.0$

Element prediction: Off

Number of isotope peaks used for $\mathrm{i}-\mathrm{FIT}=3$

Monoisotopic Mass, Even Electron Ions

6 formula( $\theta$ ) evaluated with 1 results within limits (up to 50 ciosest results for each mass)

Elements Used

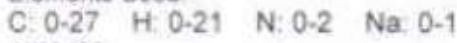

AKM 196

AKM $196111(1611$

1. TOFMSES-

B. OCe+DOO

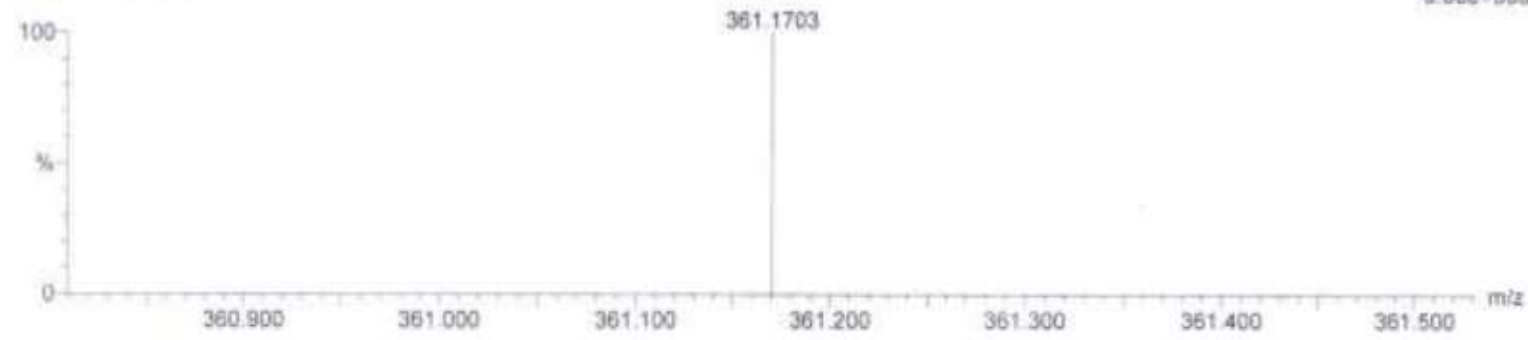

\begin{tabular}{|c|c|c|c|c|c|c|}
\hline $\begin{array}{l}\text { Xinimum: } \\
\text { Xaximum }\end{array}$ & & 5,0 & 50.0 & $\begin{array}{l}-1.5 \\
50.0\end{array}$ & & \\
\hline Masa & Colo, Mass & mba & PHA & DEE: & $1-F I T$ & Formula \\
\hline 361.1703 & 361.3705 & -0.2 & -0.6 & 17.5 & $\mathrm{n} / \mathrm{a}$ & $\mathrm{c} 26 \mathrm{H2I}$ \\
\hline
\end{tabular}

\section{HRMS of 3x}

Elemental Composition Report

Page 1

Single Mass Analysis

Tolerance $=50.0 \mathrm{PPM} / \mathrm{DBE} \min =-1.5 . \max =50.0$

Element prediction: Off

Number of isotope peaks used for $\mid-F I T=3$

Noncisotopic Mass, Even Electron lons

36 formula(e) evaluated with 1 results wathin limits (up to 50 closest results for each mass)

Elements Used

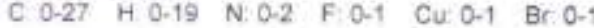

AKM-204.43 (0.797)

1: TOF MS ES.

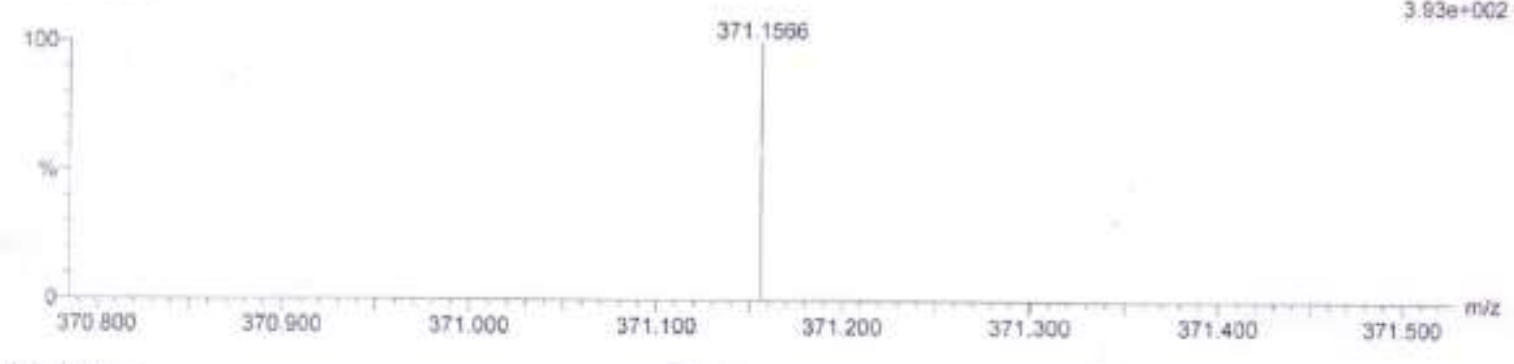

kinitinues: -1 .

Maximue: $\quad \$ 5.0 \quad 50.0 \quad 50.9$

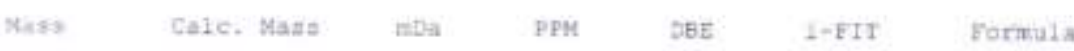

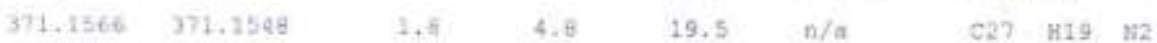

\section{HRMS of 3y}




\section{Single Mass Analysis}

Tolerance $=50.0$ PPM $\{$ DBE $\min =-1.5, \max =50.0$

Element prediction Off

Number of isotope peaks used for $\mathrm{i}-\mathrm{FIT}=3$

Monoisotopic Mass, Even Electron lons

7 formula(e) evaluated with 2 results within limits (up to 50 closest results for each mass)

Eiements Used

$\begin{array}{lllllll}C & 0-18 & H & 0-13 & \text { N: }: 0-2 & \mathrm{Na}: 0-1 & \text { S: } 0-1\end{array}$

AKM $205+39(0.723)$

1 TOF MSES.

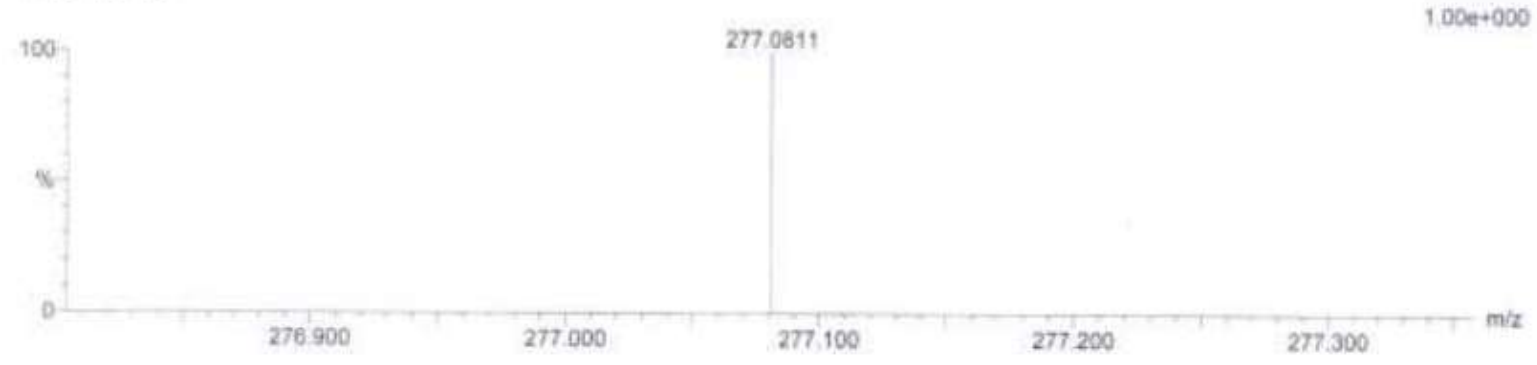

Minimum:
Maximim:

Maximum: $\quad 5.0 \quad 50.0 \quad 50.0$

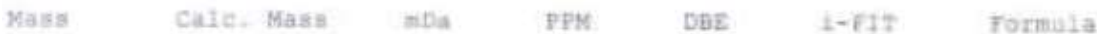

277.0612 $277.0799 \quad 1.2 \quad 4.3 \quad 12.5 \quad \mathrm{n} / \mathrm{a} \quad$ C1? H23 N2 8

\section{HRMS of 3z}

Elemantal Composition Report

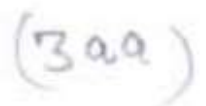

Page 1

Single Mass Analysis

Tolerance $=50.0$ PPM / DBE: $\min =-1.5, \max =50.0$

Eiement prediction Off

Number of isotope peaks used for $i-F I T=3$

Monoisotopic Mass. Even Electron lons

6 formula(e) evaluated with 1 results within limits (up to 50 ciosest results for each mass)

Elements Used

C: $0-17$ H: $0-13$

AKM 229

AKM $229100(1.466)$

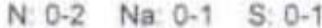

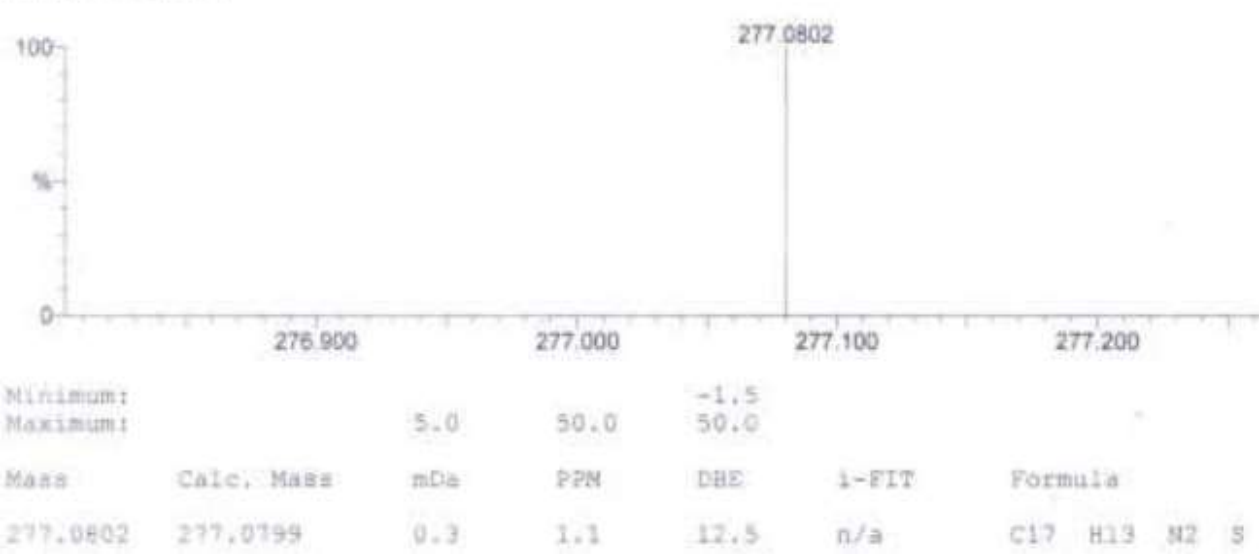

1. TOF MS ES+

HRMS of 3aa 


\section{Single Mass Analysis}

Tolerance $=50.0$ PPM $/$ DBE: $\min =-1.5, \max =50.0$

Element prediction Off

Number of isotope peaks used for i-FIT $=3$

Monoisotopic Mass. Even Electron lons

3 formula(e) evaluated with 1 results within limits (up to 50 closest results for each mass)

Elements Used

$\begin{array}{lllll}C & 0.22 & \text { H: } 0.15 & \mathrm{~N}: 0.2 & 0: 0.2\end{array}$

AKM $2.61314(0.260)$

1. TOF MSES.

$773 e+000$

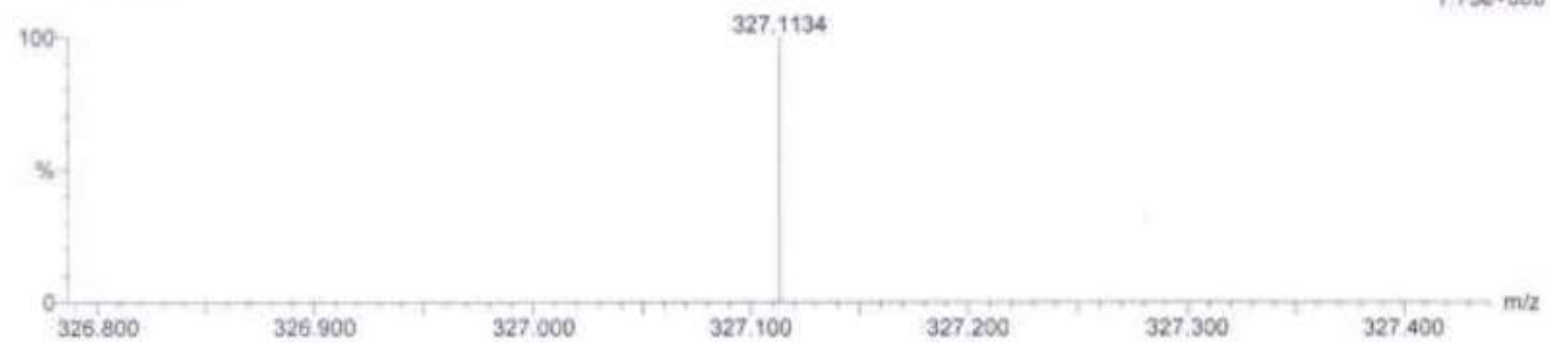

\begin{tabular}{|c|c|c|c|c|c|c|}
\hline $\begin{array}{l}\text { Minimiam: } \\
\text { Maximunt: }\end{array}$ & & 5.0 & 50.0 & $\begin{array}{r}-1.5 \\
50.0\end{array}$ & & \\
\hline Kass & Calc. Mass & $=D a$ & PPM & DaE & $1-p 1 T$ & Formula \\
\hline 927.1134 & 327.3134 & 0.0 & 0.0 & 15.5 & $\mathrm{n} / \mathrm{a}$ & C21 H15 \\
\hline
\end{tabular}

\section{HRMS of 3ab}

Elemental Composition Report

Page 1

\section{Single Mass Analysis}

Tolerance $=50.0$ PPM $/$ DBE: $\min =-1.5, \max =50.0$

Element prediction: Off

Number of isotope peaks used for i-FIT $=3$

Monoisotopic Mass. Even Electron lons

123 formula(e) evaluated with 1 results within limits (up to 50 closest results for each mass)

Elements Used

C: 0.18 H 0.14 N 0.2 F. 0.1 Na 0.1 Ct: 0.2 Eu. 0.2 To 0.2

AKM-234 $23(0.427)$

1. TOF MS ES.

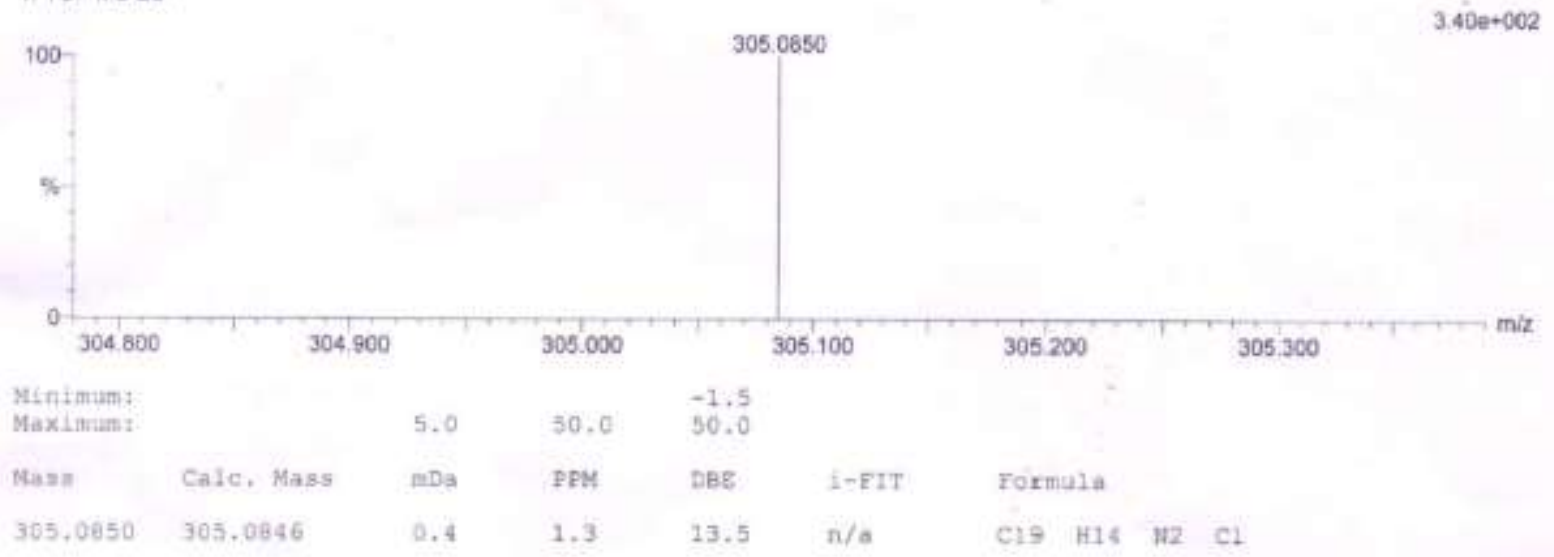

\section{HRMS of 3ac}


Single Mass Analysis

Tolerance $=50.0$ PPM $/$ DBE: $\min =-1.5, \max =50.0$

Element prediction: OHf

Number of isotope peaks used for i-FiT $=3$

Monoisotopic Mass, Odd and Even Electron lons

13 formulaie) evaluated with 1 results within limits (up to 50 closest results for each mass)

Elements Used

C: $0-20 \quad$ H: $0-13 \quad \mathrm{~N}: 0-2 \quad \mathrm{~F}: 0-1 \quad \mathrm{Na}: 0-1 \quad \mathrm{Cl}: 0-1$

AKC 236 R 41 (0.761)

1. TOF MS ES.

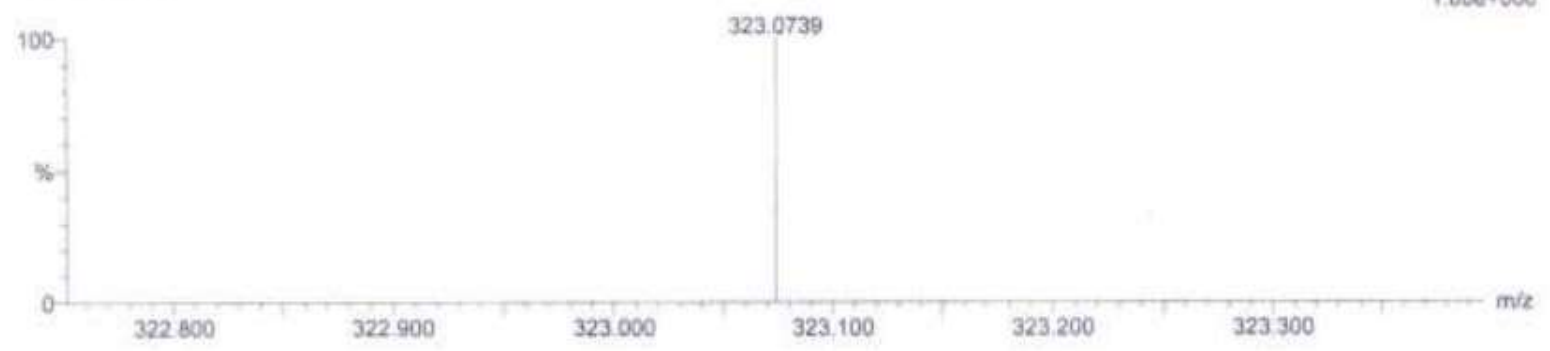

Minimum:

Maximum:

$5,0 \quad 50.0 \quad-1.5$

Masa Calc. Mass mDa PPM DEg

$323.0739 \quad 323.0751$

$-1.2$

$-3,7$

13,5

$1-212$

Formula

\section{HRMS of 3ad}

\section{Elemental Composition Report}

Single Mass Analysis

Tolerance $=50.0$ PPM / DBE $\min =-1.5, \max =50.0$

Element prediction: Off

Number of isotope peaks used for i-FIT $=3$

Monoisotopic Mass, Even Electron ions

3 formula(e) evaluated with 1 results within limits (up to 50 closest results for each mass)

Elements Used

$\begin{array}{llll}0.22 & \mathrm{H}: 0.18 & \mathrm{~N}: 0.2 & \text { Cl } 0-1\end{array}$

AKM 239 \% 10.352$)$

1. TOF MS ES+

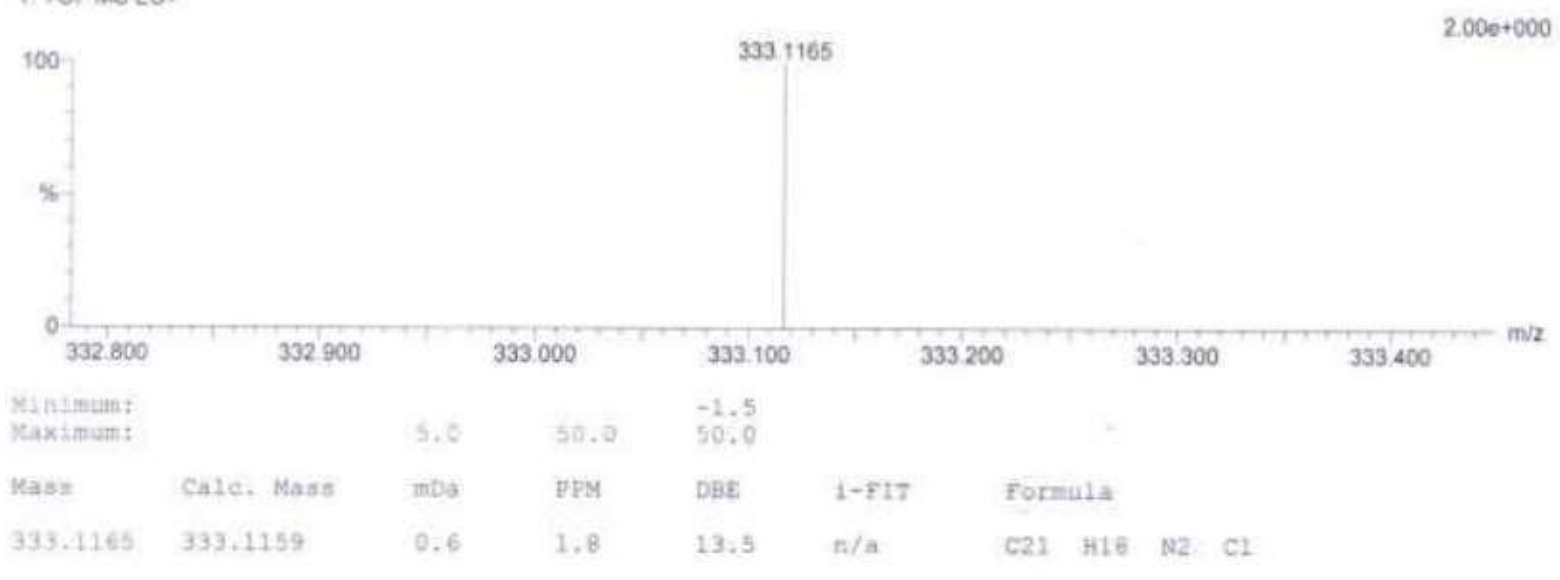

HRMS of 3ae 


\section{Single Mass Analysis}

Tolerance $=50.0$ PPM, DBE: $\min =-1.5, \max =50.0$

Element prediction. Off

Number of isotope peaks used for $1-\mathrm{FIT}=3$

Monoisotopic Mass, Even Electron lons

8 formula(e) evaluated with 1 results within limits (UD to 50 closest results for each mass)

Elements Used

$\begin{array}{lllllll}C & 0-18 & \text { H: } 0-18 & \mathrm{~N}: 0.2 & \mathrm{Na}: 0-1 & \text { Ct: } 0.1\end{array}$

AKM 2383010.557$)$

1. TOF MSES.

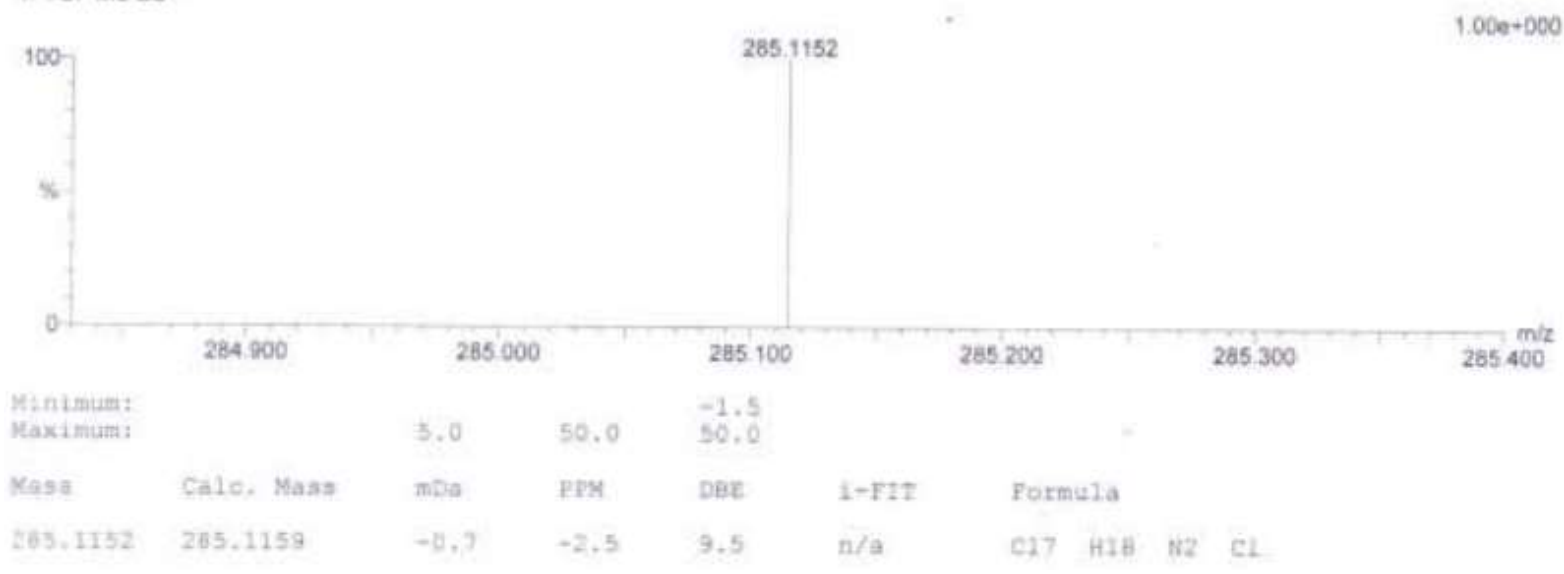

\section{HRMS of 3af}

Elemental Composition Report

Single Mass Analysis

Tolerance $=50.0 \mathrm{PPM} / \mathrm{DEE}, \min =-1.5, \max =50.0$

Element prediction: Off

Number of isotope peaks used for i-FIT $=3$

Monoisotopic Mass, Even Electron lons

14 formula(e) evaluated with 2 results within limits (up to 50 closest results for each mass)

Eiements Used

$\begin{array}{lllllll}\text { C } 0-18 & \text { H: }: 0-12 & \text { N: } 0-2 & \text { Na: } 0-1 & \text { S: } 0-1 & \text { Cl: } 0-1\end{array}$

AKM 237 R 39 (0.705)

1 TOF MSES.

$200 e+000$

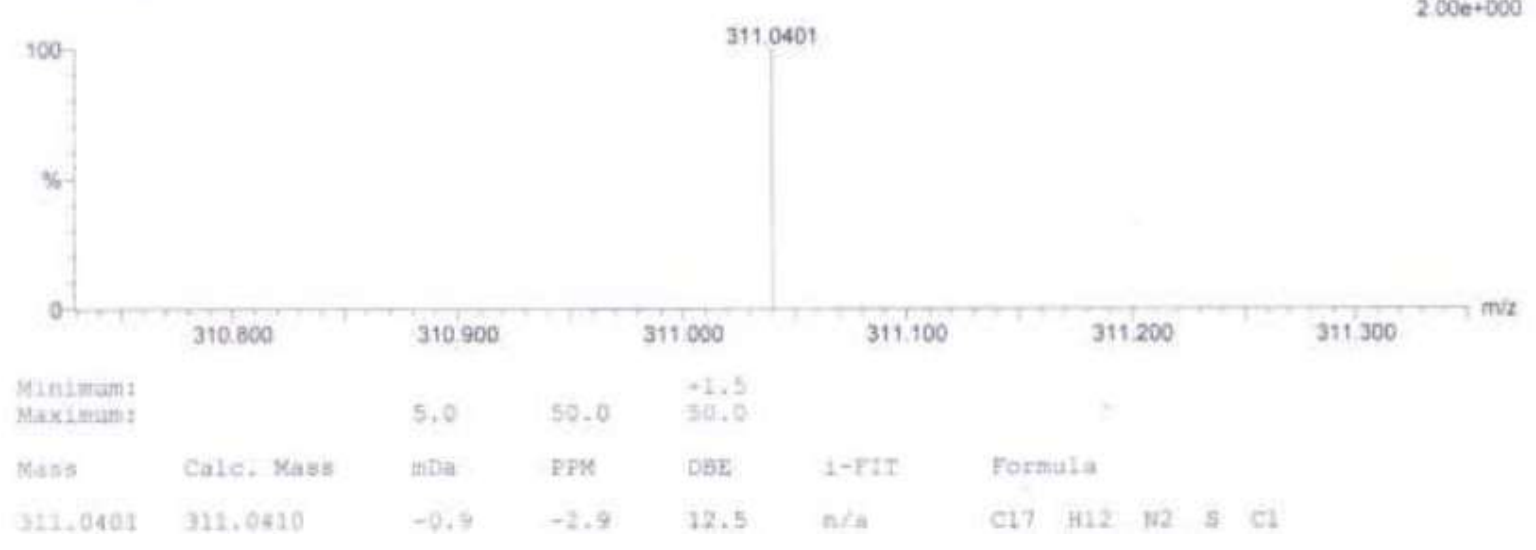

\section{HRMS of 3ag}




\section{Elemental Composition Report}

\section{Single Mass Analysis}

Tolerance $=50.0 \mathrm{PPM}$, DBE $\min =-1.5, \max =50.0$

Element prediction Off

Number of isotope peaks used for $1-F I T=3$

Monoisotopic Mass, Even Electron lons

5 formula(e) evaluated with 1 results within limits (up to 50 closest results for each mass)

Elements Used

$\begin{array}{llll:l}\text { C: } 0.18 & \text { H: } & 0.19 & \text { N: } 0.2 & \text { Na: } 0.1\end{array}$

AKG 220

AKM $22073(1,054$

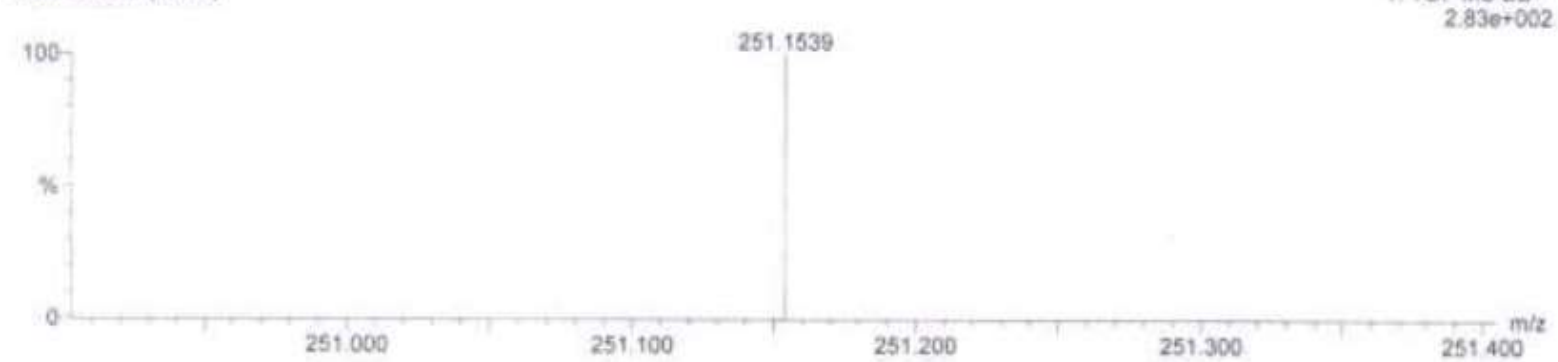$$
251+100
$$

251200

251400

\begin{tabular}{|c|c|c|c|c|c|c|}
\hline $\begin{array}{l}\text { Menumim: } \\
\text { raxitiais: }\end{array}$ & & 5.0 & 50,0 & $\begin{array}{l}-1.5 \\
50.0\end{array}$ & & \\
\hline Kats & Calc. Mass & moa & PPM & DaE & i-FIT & Formula \\
\hline 251.1539 & 252,7548 & -0.9 & $-3,6$ & 9.5 & $n / s$ & $\mathrm{C} 17 \quad 419$ \\
\hline
\end{tabular}

\section{HRMS of $4 b$}

\section{Elemental Composition Report}

\section{Singie Mass Analysis}

Tolerance $=50.0 \mathrm{PPM}, \mathrm{DBE}: \min =-1.5 . \max =50.0$

Element prediction: Off

Number of isotope peaks used for $\mathrm{i}-\mathrm{FIT}=3$

Monoisotopic Mass, Even Electron Ions

5 formula(e) evaluated with 1 results within imits (up to 50 ciosest results for each mass)

Elements Used

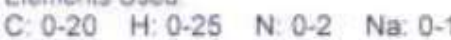

AXMM192

AKM192 $20(0.646)$

1. TOF MS ES.

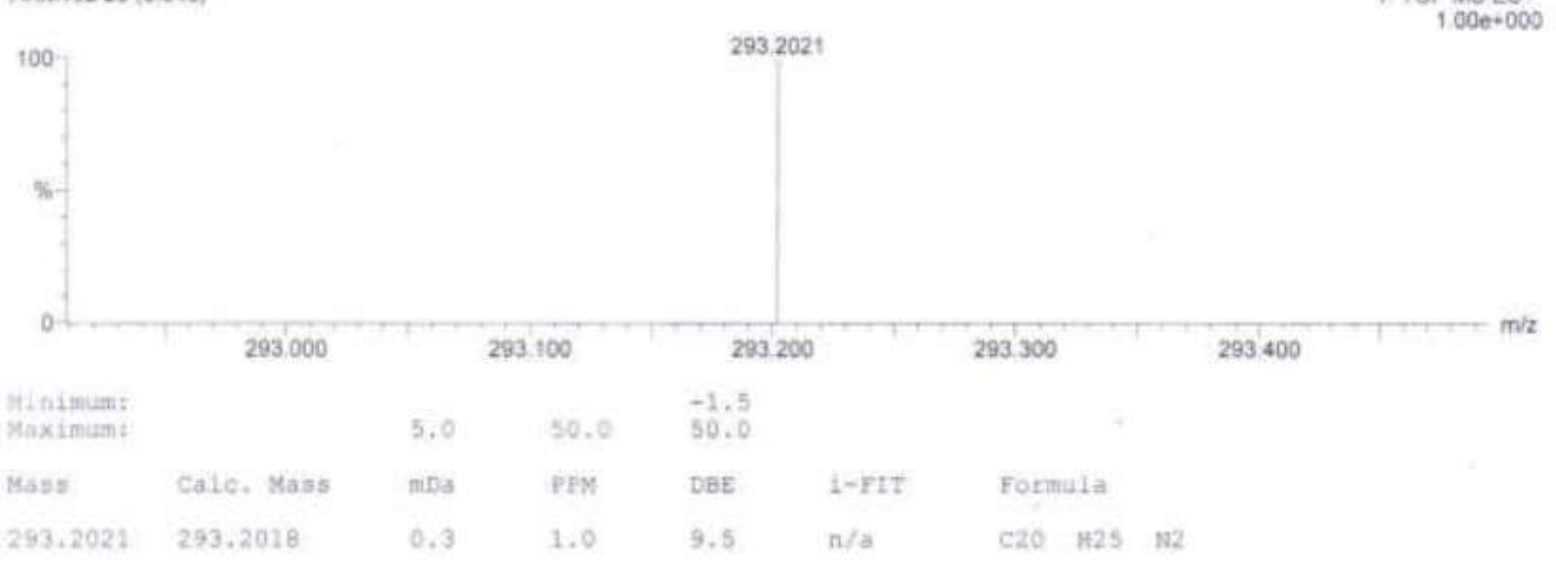

\section{HRMS of 4d}


Single Mass Analysis

Tolerance $=50.0$ PPM $/$ DBE $\min =-1.5 . \max =50.0$

Elemint prediction: Off

Number of isotope peaks used for $i \cdot-\mathrm{FIT}=3$

Monoisotopic Mass Even Electron lons

4 formula(e) evaluated with 2 results within limits (up to 50 closest results for each mass)

Elements Used

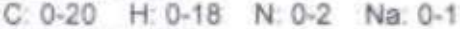

AKM 2084110.761

1 TOFMS ES.

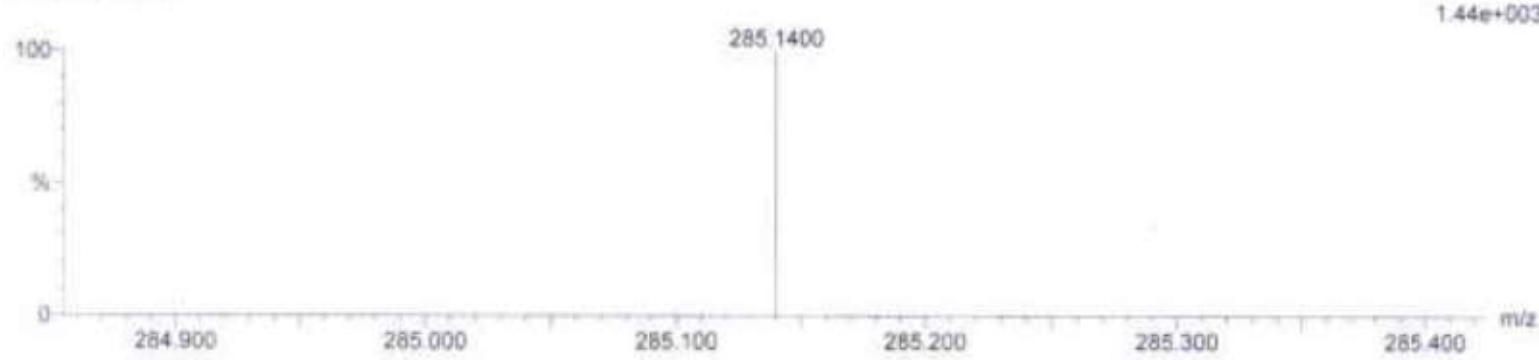

\begin{tabular}{|c|c|c|c|c|c|c|}
\hline $\begin{array}{l}\text { Minithum: } \\
\text { Maximum: }\end{array}$ & & 5.0 & 50.0 & $\begin{array}{l}-1.5 \\
30.0\end{array}$ & & \\
\hline fass & Caze. Masa & $m b a$ & PEX & DEE & $1-E 1 T$ & Formusa \\
\hline 45.1400 & 245.1392 & Q. B & 2, 3 & 13.5 & $\mathrm{n} / \mathrm{a}$ & c20 H:7 \\
\hline
\end{tabular}

\section{HRMS of 4e}

Elemental Composition Report

Single Mass Analysis

Tolerance $=50.0$ PPM $/$ DBE: $\min =-1.5, \max =50.0$

Element prediction: Off

Number of isotope peaks used for $\mathrm{i}-\mathrm{FIT}=3$

Monoisotopic Mass. Even Electron Ions

2 formula(e) evaluated with 1 results within limits (up to 50 closest results for each mass)

Eiements Used

$\begin{array}{llll}C & 0-22 & \text { H: } 0.19 & \mathrm{~N}: 0-2\end{array}$

AKCM 224322710.501

1 TOF MS ES.

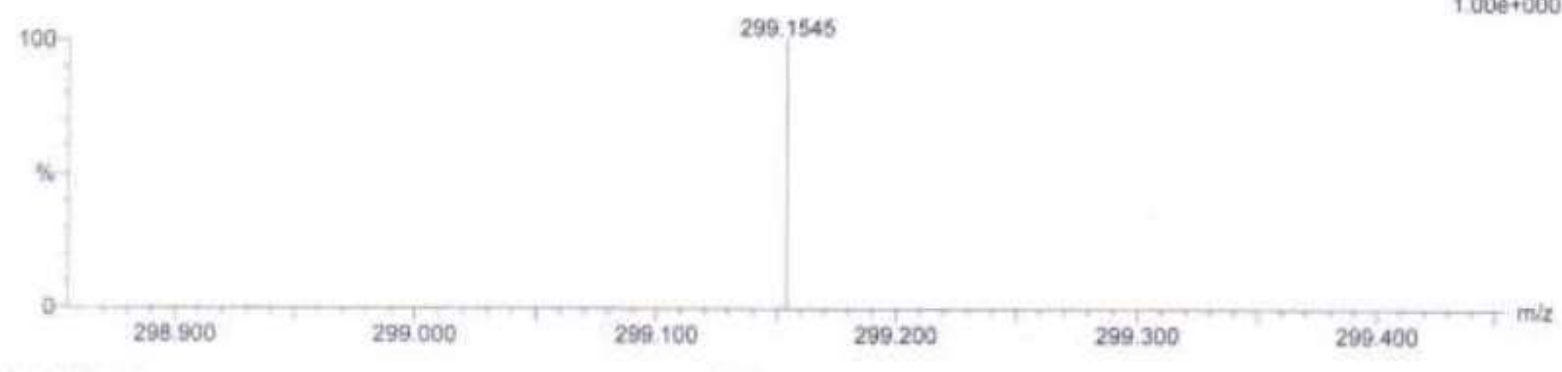

\begin{tabular}{|c|c|c|c|c|c|c|}
\hline $\begin{array}{l}\text { Minimiar: } \\
\text { Maximim: }\end{array}$ & & 5.0 & 50.0 & $\begin{array}{l}-1.5 \\
50.0\end{array}$ & & \\
\hline Yass & Calc, Mass & $m D a$ & PFE & DEE & $1-F+T$ & Formula \\
\hline 99.1 .545 & 299.1548 & -0.3 & -1.0 & 13.5 & $\mathrm{n} / \mathrm{a}$ & czis H19 \\
\hline
\end{tabular}

HRMS of $4 f$ 


\section{Single Mass Analysis}

Tolerance $=50.0$ PPM / DBE $\min =-1.5, \max =50.0$

Element prediction: Off

Number of isotope peaks used for $\mathrm{I}-\mathrm{FIT}=3$

Monoisotopic Mass. Even Electron ions

2 formula(e) evaluated with 1 results within limits (up to 50 closest results for each mass)

Elements Used

C. $0.25 \quad$ H: $0-19 \quad \mathrm{~N}: 0-2$

A.KM 225

AKCM $22576(1093)$

$8.56 \mathrm{e}+000$

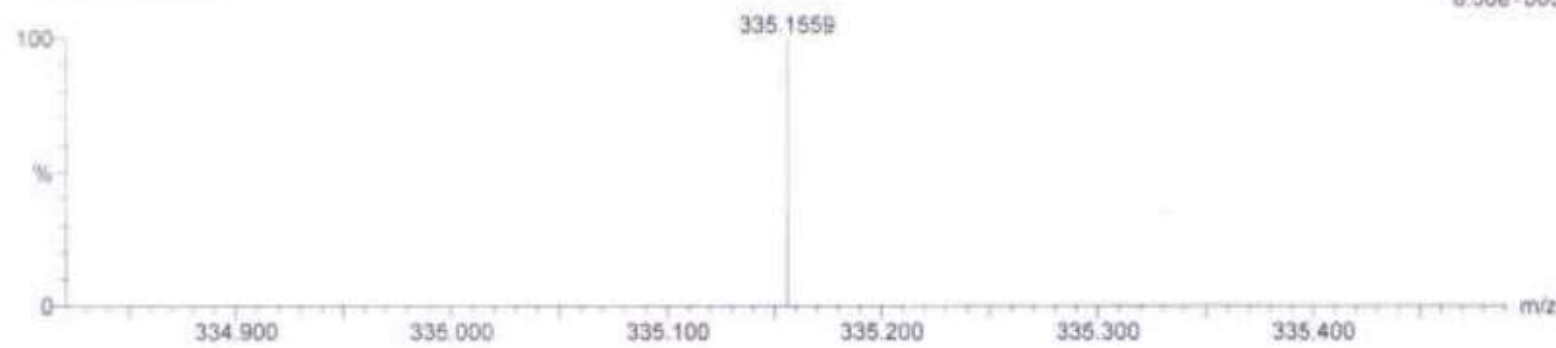

\begin{tabular}{|c|c|c|c|c|c|c|}
\hline $\begin{array}{l}\text { Minimumi } \\
\text { Maximumt: }\end{array}$ & & 5.0 & 50,0 & $\begin{array}{l}-1.3 \\
50.0\end{array}$ & & \\
\hline Massar & Calo. Mass & $\mathrm{mba}$ & PPN & DAE: & $1-517$ & Fornu:a \\
\hline 15.1559 & 355.1568 & 1.1 & 3.3 & 26.5 & $\mathrm{a} / \mathrm{a}$ & $\mathrm{C} 24$ \\
\hline
\end{tabular}

\section{HRMS of $4 \mathrm{~g}$}

Elemental Composition Report

Page 1

\section{Single Mass Analysis}

Tolerance $=50.0$ PPM / DBE $\min =-1.5, \max =500$

Element prediction. Off

Number of isotope peaks used for $\mathrm{I}-\mathrm{FIT}=3$

Monoisotopic Mass. Even Electron lons

5 formula $(\theta)$ evaluated with 1 results within limits (up to 50 ciosest results for each mas5)

Elements Used

$\begin{array}{llll}\text { C } 0.20 & \text { H: } 0.19 & \text { N: }: 0.2 & \text { Na: } 0-1\end{array}$

AKMV 211

AKM $211161(2326)$

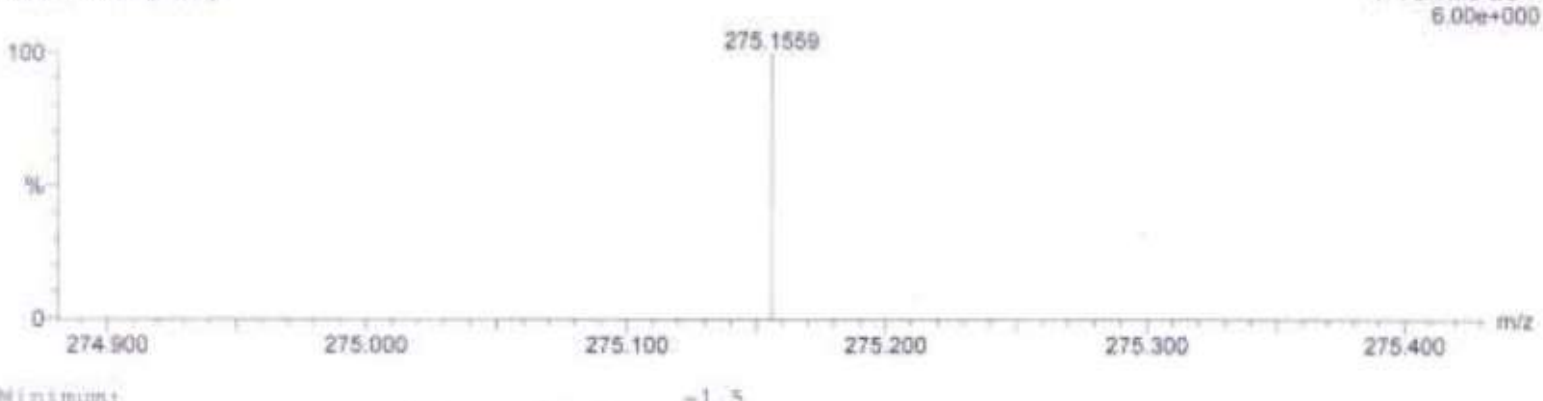

Mininien:

Maximuan:

Mass 